\title{
CORPORATE GOVERNANCE IN ITALY: \\ STRONG OWNERS, FATTHFUL MANAGERS. \\ AN ASSESSMENT AND A PROPOSAL FOR REFORM
}

\section{Lorenzo Stanghellini*}

\section{INTRODUCTION}

II. The Italian System of Corporate Governance: The Legal, FRAMEWORK
A. The Legal Sources of Italian Private Law: The Civil Code.
B. The Legal Sources of Italian Corporate Law. The Different Role of the Civil Code and the Relevance of Special Laws.
C. Corporate Governance Rules: The Absence of Significant Changes Since the Enactment of the Civil Code.
D. The Società per Azioni as the Model of Italian Corporate Law: The Reasons for a Choice.
E. The Protagonists of the Governance of the Società per Azioni.
1. The Shareholders.
2. The Board of Directors.
3. The Board of Auditors.
F. Summary of Part II.

III. THE SYSTEM OF CORPORATE DIRECTORS' LIABILITY: THE LAW
A. The "Tortious Interference" Liability of Directors to Creditors.
B. The General Tort Law Liability of Directors to Shareholders and Third Parties.
1. The Grounds.
2. The Procedure.
C. The Liability of Directors to the Company.
D. Summary of Part III.
IV. LAW AND SOCIETY: THE ITALIAN INDUSTRIaL SyStem aND tHE OWNERSHIP STRUCTURE OF ITALIAN COMPANIES.

* Lorenzo Stanghellini is Assistant Professor of Law, University of Florence, Italy. J.D., University of Florence (1987); LL.M. Columbia University (1995). I am grateful to Professors Ronald J. Gilson and Francesco Corsi for helpful comments. The paper benefited also from colloquia with Professors John C. Coffee, Jr., Harvey J. Goldschmid, Jeffrey N. Gordon and Henry Hansmann. I am particularly indebted to Bernard Alter and Leeanne T. Sharp for helping me edit the text. Invaluable support during my stay at Columbia University came from Professor Walter Gellhorn. The Italian Academy for Advanced Studies in America at Columbia University gave me precious logistic assistance and allowed me to present an earlier draft of this paper at a seminar on April 13, 1995. Helpful comments came from the participants, and particularly from Bal Gopas Das, Lorenzo Borgogni, Pierre-Henry Conac, Gabor Molnar, Bruno Louis Ranger, Laura Ristori, Efrat Safran, and Leeanne T. Sharp. My stay in the United States was partially supported by a grant from the Italian National Research Council. The opinions expressed in the paper are solely my own. 
A. An Industrial System Based on Small Firms.

B. A Follow-up: The Insufficiency of Data on Industrial Size in Assessing the Efficiency of the Italian Industrial System as a Whole.

C. The Important Role of the Public Enterprise System.

D. The Ownership Structure of Unlisted Companies.

E. The Ownership Structure of Listed Companies.

F. Expanding the View: The Structure of the Control Group in Listed Companies.

G. Shareholders' Agreements as Non-legal, or At least Only Partly Legal, Institutions of Governance of Italian Companies.

H. The Nature and the Structure of the Control Group of Italian Companies.

I. Factors Determining the Concentrated Italian Ownership Structure.

J. Completing the View. Factors Determining the Ownership Structure as a Whole: Long-term Entrepreneurs and Shortterm Companions.

K. Italian Corporate Governance: Some Final Remarks. The Majority Stake as the Most Important Institution of Italian Capitalism.

L. The Way Ahead: The Foreseeable Developments.

M. The Need to Reform the System to Provide Strong Minority Monitoring.

N. Summary of Part IV.

V. CoRPORATE GoVERnANCE IN ITALY AND THE SYSTEM OF DIRECTORS' LIABILITY: A PROPOSAL FOR REFORM

A. Directors' Accountability: Who are the Plaintiffs in Liability Suits against Directors?

B. Minority Shareholders' and Directors' Liability: How Many Explicit Attempts? How Many "Undercover" Liability Suits against Directors?

C. Directors' Liability Legal Framework in Action: Who is Protected against Whom?

D. Concentrated Ownership Structure and Majority Vote: Spontaneous Incentives versus Optimal Deterrence. The Different Situations of the Duty of Care and of the Duty of Loyalty.

E. The Consequences of the Problematic Enforcement of the Duty of Loyalty.

F. What Role for Derivative Actions based on Violations of the Duty of Loyalty in Italian Corporate Governance? A Possible Contribution to the Implementation of the "Mutability Principle"? 


\section{G. Summary of Part V.}

VI. Conclusion: What PaRT for the OWNers of the Firm in a MATURE ECONOMY?

\section{INTRODUCTION}

The goal of this paper is to provide some insight into the Italian corporate governance system. It has been said that "[i]n an overall economic perspective two main models of control have emerged: systems which utilize the market as a monitor (for example, the market for corporate control as particularly in the United States and Great Britain), and systems of control in which banks and fellow corporations function as monitors (as in Germany and Japan)."1 This is doubtful. I think Italy represents a third model in which entrepreneurs as shareholders have remained in control and influence the corporate policy rather than simply monitor more or less independent managers.

Even though important changes in the Italian corporate landscape are now taking place, and more are to be expected in the future, the present governance pattern will remain the same for several years to come. Is Italy an anomaly, thus not worthy to be studied? I do not think so. Italy could be a useful subject of study for corporate governance specialists, to be added to the much studied countries of the former Communist Bloc. The lesson is that, when certain conditions are met, the owners of the enterprises may retain a part-indeed, an important one-even in a mature economy. Therefore, separation of ownership and control must be explained in a historical perspective, and cannot simply be taken for granted once the economy develops.

In order to familiarize the reader with corporate governance in Italy, Part II gives the reader a general background of Italian corporate law and structure, providing information on what is strictly necessary for the correct understanding of the paper's main theme. It is not intended to be a substitute for direct knowledge of the matter, which can be acquired only through a reading of the various manuals and treatises on the subject. ${ }^{2}$

1. Klaus J. Hopt, Preface to InStituTiOnAL InVESTORS AND CORPORATE GovernANCE 1, 2 (Theodor Baums et al. eds., 1994).

2. A selective bibliography includes the following texts (listed in alphabetical order):

(a) Manuals

(1) GiusePpe Auletta \& Niccolo' Sal.anitro, Diritto commerciale (9th ed. 1994).

(2) Gian Franco Campobasso, DiritTo commerciale, in three volumes: 1 DiRitTo DELL'IMPRESA (2d ed. 1993); 2 DiRITTO DELLE SOCIETÀ (2d ed. 1992); 3 CONTRATTI - TITOLI DI CREDITO - PROCEDURE CONCORSUALI (1992).

(3) Gastone Cottino, Corso di diRTtTo commerciale, in two volumes: 1 (3d ed. 1993); and 2 (3d ed. 1994).

(4) Franco Di Sabato, Manuale delle società (4th ed. 1992). 
Details, often important ones, sometimes have been passed over or simply have been referred to in the footnotes, with an indication of sources where they are appropriately discussed. Those familiar with the subject may simply skip Part II, and those who are interested in its conclusions can find them in Section II.F.

Part III explores the legal framework of directors' liability under the particular prism of the balance of power between majority and minority. Particular focus is on the Civil Code rule requiring a majority vote for an action against directors to be brought by the company and its significance as a governance tool. Conclusions can be found in Section III.D.

Part IV analyzes the structure of the Italian industrial system and the ownership pattern of Italian companies. The result of this analysis is that the dominant institution of Italian corporate governance is direct involvement of large shareholders, either alone or associated in a structured control group. Synthetic conclusions are drawn in Section IV.N.

Part V, starting from the analysis of the existing "case law" concerning directors' liability, suggests a change in the legal rules of corporate governance concerning minority suits against directors. Such change is necessary to pave the way for new organizational forms, in which the role of particular kinds of minority shareholders-namely, institutional investors-will be of critical importance. Findings and proposals are summarized in Section V.G.

\section{THE ITALIAN SYSTEM OF CORPORATE GOVERNANCE: THE LEGAL FRAMEWORK}

\section{A. The Legal Sources of Italian Private Law: the Civil Code.}

The Italian Codice Civile [hereinafter Civil Code] was enacted on March 16, 1942. At that time, Italy had been ruled by the Fascist government for almost twenty years and was at war. Badly equipped Italian armies had recently joined the armies of Germany in the invasion of Soviet Union, which later proved to be one of the turning points of World War II.

(5) Francesco Ferrara \& Francesco Corsi, Gli imprenditori e le societa (9th ed.

(6) GIUSEPPE FERRI, MANUALE DI DIRITTO COMMERCIALE (9th ed. 1993).

(7) Francesco Galgano, Diritto commerciale, in two volumes: 1 Diritto DELL'IMPRESA (4th ed. 1991); 2 DiRTTTO DELLE SOCIETÀ (4th ed. 1991).

(8) Per GiUsto JAEGER \& FrANCESCO DENOTZA, APPUNTI DI DIRITTO COMMERCIALE (3d ed. 1994).

(b) Treatises

Trattatodelue società per azioni, (Giovanni E. Colombo \& Giuseppe B. Portale eds.) (Eight volumes of a scheduled ten have been published). 
Notwithstanding the tragic circumstances in which it was passed, the Civil Code is a fairly sophisticated product. Excellent scholars with an extensive knowledge of comparative law and of the French and the German legal systems in particular contributed to the debate over the reform, a debate which lasted several years.

Enacted together with a new Code of Civil Procedure, the Civil Code was the result of a merger of the Civil Code project with the Commercial Code project, and replaced both the first Italian Civil Code of 1865 and the second Commercial Code of $1882{ }^{3}$ In the merger of civil and commercial principles, the latter generally prevailed. ${ }^{4}$ According to the emphatic Official Report of the Ministry of Justice on the Civil Code, the reform marked the triumph of the new principles of economic activity over the old Roman structure based on property rights.

The structure of the Civil Code, after the pruning of a few tributes to the Fascist regime, ${ }^{5}$ has since withstood radical changes in both the political and

3. In 1865, five years after the reunification of Italy, a Civil Code, a Commercial Code, and a Code of Civil Procedure were enacted. While both the Civil Code and the Code of Civil Procedure lasted until 1942, the Commercial Code was replaced in 1882.

4. This process has been called "commercialization of private law." FERRARA \& CORSI, supra note 2, at 15. 2 TULLIO ASCARELLI, Il dialogo dell 'impresa e della società nella dottrina italiana dopo la nuova codificazione, in PROBLEMI GIURIDICI 781, 783 (1959), observing the seamlessness of the process of unification of civil and commercial law in legal practice, affirmed that "the unification of civil and commercial law was welcomed . . . as a ripe and foreseen fruit."

5. The Civil Code rested in part on the authority of the so-called "corporazioni," nondemocratically elected political bodies, entitled to enact and enforce rules of economic policy subordinated to the law. See Widar Cesarini Sforza, Corporativismo, in 10 ENCICLOPEDIA DEL DIRITTO 664, 667-68 (1962) (the Italian was only a nominal corporatism, as it came authoritatively from the State; moreover, "It]he myth of the nation and of the national interest [have] proven ... to be unable to curb the interests of the strongest classes, composed by capitalists and leaders of enterprises."); see also Luisa Riva-Sanseverino, Corporazione (Diritto comorativo), in 10 ENCICLOPEDIA DEL DIRTTTO 679 (1962). The corporazioni were abolished and the norme corporative [corporative rules] were generally repealed by the Royal Decree of Aug. 9, 1943, No. 721, a few days after the breakdown of the Fascist regime and a month before the signing of the armistice with the Allies and by Decree of the Lieutenant of the Kingdom of Nov. 23,1944 , No. 369. Other minor amendements (although important from the civil rights standpoint) related to the change of the political regime were implemented between 1943 and 1945.

For the influence of Fascist ideology on the Civil Code, see generally RAFFAELE TETI, CODICE CIVILEE REGIME FASCISTA, SULL'UNIFICAZIONE DEL DIRTTTO PRIVATO (1990); on the Fascist notion of enterprise as a quasi-public community of interests, where the entrepreneur (or the directors) and the workers overcome class war for the superior benefit of the Unternehmen an sich (and of the Nation in general), see the illuminating pages of 2 ASCARELLI, supra note 4, at 786-89. While in the participative model, the composition of the various interests is internalized in the board of directors, in the corporative model, as interpreted by the Fascist regime, such composition was to be achieved by the action of the entrepreneur (or of the board of directors, formed by his representatives alone), who supposedly acted in the general interest (see generally DISIANO PRETE, L'“ ABUSO" DEL LA REGOLA DI MAGGIORANZA NELLE DELIBERAZIONI ASSEMBLEARI DELLE SOCIETÀ PER AZION1 195 \& n. 62 (1992)). 
economic situations. The enactment of the new Constitution in 1948, resting on radically different principles, has led to some partial reforms ${ }^{6}$ and to a few interventions by the Constitutional Court, but has not created the need for a complete revision of the Civil Code. Some of its provisions, moreover, have given the courts an exceptionally wide latitude in adapting apparently unchangeable rules to changing times. ${ }^{7}$

The Civil Code of 1942 is the principal source of Italian private law, and it is likely that this will continue for many years to come. Some laws dealing with special aspects of private law (e.g., adoption, consumer protection, and labor law) have been enacted, but, unlike what has happened concerning other major pieces of Fascist legislation, the need for a general reform of the Civil Code is not perceived. ${ }^{8}$

\section{B. The Legal Sources of Italian Corporate Law. The Different Role of the Civil Code and the Relevance of Special Laws.}

The story regarding the part of the Civil Code that deals with business organization has been less static and is somewhat peculiar. Business organization law is contained in articles 2060 to 2642 of the Civil Code. ${ }^{9}$ Articles 2325 to $2497-b i s$ of the Civil Code deal specifically with the three possible forms of corporations: the società per azioni [stock company], the società in accomandita per azioni [stock company with personally liable directors], and the società a responsabilità limitata [limited liability company]. The legislative model is the società per azioni: the rules of the società in

6. The family law section of the Civil Code arts. 79 to 455 , for example, was extensively amended by the Law of May 19, 1975, No. 151.

7. Two significant examples of adaptation of the law by means of case law are Civil Code arts. 1375 and 2043. The former, which prescribes a bona fide execution of the contract by the parties, was long considered nothing more than a formula without any binding significance and is now being reevaluated by the courts. The latter, which is a general provision on torts, was first interpreted as including only damages to the body and to property and now is used to grant recovery for any kind of tort. For an excellent assessment of the role of so-called "general clauses," see LiNA BIGLIAZZI GERI ET AL., 1 DiRITTO cIVILE 19 (1987); on the evolution of art. 2043, see LINA BIGLIAZZI GERI ET AL., 3 DIRITTO CIVILE 671-93 (1992).

8. It seems fair to say that of the four major pieces of Italian legislation originating in the Fascist era (Civil Code, Code of Civil Procedure, Criminal Code, and Code of Criminal Procedure), the Civil Code is considered the most satisfactory. The Code of Civil Procedure is currently in legislative trouble, and a reform, extensive as well as controversial, has come into force in May 1995. The debate over the reform of the Criminal Code has led to a complete project prepared by a Ministerial Committee; an entirely new Code of Criminal Procedure was enacted in 1988 and has been in force since 1989.

9. There are some provisions included by attraction in other parts of the Civil Code. For example, art. 320 , in which the fifth paragraph deals with the business activity of underage children, is in the family law section. 
accomandita per azioni and the società a responsabilità limitata are largely construed by cross-references to the rules of the società per azioni.

Each type of corporate legal structure was conceived to fit different factual patterns. The società per azioni was designed as an organizational form for medium-large businesses. The società in accomandita per azioni, which has proven mainly a doctrinal creation, was intended as a device to raise capital by a personally liable entrepreneur, well known to and trusted by the public. ${ }^{10}$ The società a responsabilità limitata was devised as a small-business limited liability corporation, a role which it has widely played since its introduction.

The corporate law part of the Civil Code, unlike other parts of it, has been amended several times. The main thrust of change has been provided by the directives of the European Community (now European Union), nine of which deal directly or indirectly with corporate law and were implemented between 1969 and 1993." However, other powerful forces, principally the rapid development of non-banking financial intermediation since the early ' 70 s, have been at work in shaping the landscape.

The result is a Civil Code flanked by a number of laws dealing with particular areas. ${ }^{12}$ Even so, when financial markets are not directly involved (in

10. The societd in accomandita per azioni seems suitable for what Professor Robert $C$. Clark defines as the first stage of capitalism: "the age of the entrepreneur, the fabled promoterinvestor-manager who launched large-scale business organizations in corporate form for the first time in history .... He was primarily a nineteenth century phenomenon." Robert C. Clark, The Four Stages of Capitalism: Reflections on Investment Management Treatises, 94 HARV. L. REV. 561,562 (1981). The Italian economy, even if it had developed later than the American economy, had already passed the "first stage" in 1942, in effect, causing the societd in accomandita per azioni to be born old-fashioned; or possibly personal liability for large-scale enterprises has never been an acceptable compromise for entrepreneurs, given the alternative of the fully limited liability easily achievable by means of the societd per azioni. The societd in accomandita per azioni is nonetheless living its first life in a totally different context from that the writers of the Civil Code had in mind. This strange corporate form is, in fact, being used as a top holding company for large business groups. The high stability of the personally liable directors, who cannot be removed by a simple shareholders' vote, and the relative unlikeliness of a financial breakdown of a company not involved in direct economic activity (either operating or financial), can render the form of the societa in accomandita per azioni attractive for this use. For example, at the top of the Fiat group pyramid (a group with $\$ 20$ billion turnover in 1994) is the "Giovanni Agnelli \& C. società in accomandita per azioni," whose (interesting) charter was published in 1987 GIURISPRUDENZA COMMERCIALE I, 1027.

11. Four more directives are in project stage, but their adoption seems doubtful at the present moment.

12. The most important of which are:

(a) Law of June 7, 1974, No. 216, on the financial market in general and on public offerings of securities; it created the Commissione nazionale per le societa e la borsa [National Commission for Companies and Stock Market, hereinafter CONSOB, an independent agency modeled after the American SEC]. It is the main piece of legislation on the matter. This law has been amended innumerable times to respond to changes in the financial markets and to implement European directives; 
which case directors must follow substantive rules of disclosure and independent auditors play some role) the corporate structure rules are to be found in the Civil Code.

\section{Corporate Governance Rules: the Absence of Significant Changes Since the Enactment of the Civil Code.}

This intense legislative activity with respect to corporate law, apart from a few exceptions, has not touched the corporate governance field. The basic structure of the relationship between the shareholders, the board of directors, and the board of auditors, ${ }^{13}$ which are the three organs of the corporation, has remained basically unchanged since 1942 .

The immediate reasons for this peculiarity can easily be found. First, the European Union's directives, which have been the main legislative driving force, have touched corporate governance only marginally. The proposal for a Fifth European Directive concerning "the structure of public limited companies, and the powers and obligations of their organs," which would be the central text on European corporate governance, has proven very difficult for the member states to reach agreement on, and it is very likely that it will not be adopted in the near future, if ever. ${ }^{14}$ Should such a directive be adopted, some corporate governance rules would change, but, except for the very unlikely case that the German model

(b) Law of Mar. 23, 1983, No. 77, on open-end mutual funds, extensively amended in 1992 to implement two European directives on the matter;

(c) Law of Jan. 2, 1991. No. 1, on the financial market and on societd di intermediazione mobiliare, general name for companies engaged in the business of broker-dealer, financial advisor, etc. (apart from two categories partially "grandfathered" by the law, only societa di intermediazione mobiliare and banks can publicly perform such activities);

(d) Legislative Decree of Apr. 9, No. 127, on consolidated financial reports [a Legislative Decree is enacted by the Government on delegation of powers by the Parliament and is equal in authority to a Law];

(e) Law of May 17, 1991, No. 157, on insider trading;

(f) Legislative Decree of Jan. 27, 1992, No. 88, on revisori contabili [auditors];

(g) Law of Feb. 18, 1992, No. 149, on tender offers;

(h) Legislative Decree of Apr. 21, 1993, No. 124, on private pension funds;

(I) Law of Aug. 14, 1993, No. 344, on closed-end mutual funds.

13. We will deal with each of these organs later.

14. This is the forecast of COOPERS \& LYBRAND, EC COMMENTARIES, Mar. 2, 1995, available in LEXIS, World Library, ALLWLD File. The last official steps on the subject were a vote of the European Parliament on the second draft proposal of second amendment, on July 10, 1991, and a third amendment to the proposal made by the Commission in the fall of 1991 . The proposal, however, has not been included in the list of those to be scrapped or amended under the European Community "subsidiarity drive" that followed the resistance encountered by the Maastricht Treaty in 1992 (source: REUTER TEXTLINE, Dec. 9, 1992, available in LEXIS, World Library, ALLWLD File). The most difficult subject has proven to be the role of workers in corporate governance. 
of workers' codetermination is mandated by the directive, a complete revolution would probably not occur.

Second, the development of financial markets has been substantial, but it has turned out to be compatible with, or has adapted to, the old rules of governance. As we will see later, the system of corporate governance was conceived with a strong monitoring role of the shareholders in mind (even in listed companies), and this continues to be true. In every Italian company, publicly or privately held, there is a controlling shareholder or a group of influential shareholders tied by strong economic and contractual relationships. The public company, as studied by Adolf Berle and Gardiner Means, ${ }^{15}$ and recently by Mark Roe, ${ }^{16}$ does not exist in Italy. The vigorous development of Italy, which has led it to become the fifth industrial power in the world, ${ }^{17}$ has put the Italian corporate structure on a path different from the American one.

Let us start with a look at the substantive rules; first in general, and then with particular focus on the directors' liability rules. Then, we will move to the characteristic patterns of Italian corporate governance using some economic and statistical data. Next, we will examine Italian corporate governance law in action, looking closely at case law. Finally, we will assess the suitability of the present rules of directors' liability for the Italian system.

\section{The Società per Azioni as the Model of Italian Corporate Law: the Reasons for a Choice.}

As we have seen before, the legislative model for Italian corporate law is the società per azioni. The disciplines of the società in accomandita per azioni and the società a responsabilità limitata borrow from that of the società per azioni, the only one of the three that is complete and self-standing.

Moreover, even if the società a responsabilità limitata is the dominant form, ${ }^{18}$ it is less and less common as the firm's size increases. Its capital structure is limited to one class of voting shares, ${ }^{19}$ which cannot be transferred

15. Adolf A. Berle, JR. \& Gardiner C. Means, The Modern Corporation and PRIVATE PROPERTY (1932).

16. MARK J. RoE, Strong MaNaGers, Weak OWNERs (1994).

17. According to the 1995 WORLD BANK ATLAS, in 1993 Italy's gross output, as measured by goods and services, was (in U.S. dollars) $\$ 1.135$ trillion ranking fifth in the world, behind the United States ( $\$ 6.388$ trillion), Japan ( $\$ 3.927$ trillion), Germany ( $\$ 1.903$ trillion), and France ( $\$ 1.289$ trillion), and ahead of the United Kingdom ( $\$ 1.042$ trillion).

18. As of September 30,1993 , about 36,750 societd per azioni and 336,000 societd a responsabilitd limitata were active in Italy (source: data CERVED, analyzed in L'azienda cambia vestito, IL SOLE - 24 ORE, Nov. 15, 1993, at 1).

19. GIAN CARLOM. RiVOLTA, LA SOCIETA A RESPONSABILITẢ LIMITATA $170-74$ (1982);

2 CAMpobasso, supra note 2 , at 499 \& n. 1. 
through share certificates. ${ }^{20}$ Its debt financing is limited to trade credit and direct borrowing, ${ }^{21}$ and it cannot be listed on stock exchanges. ${ }^{22}$ Higher cost of financing, however, cannot account entirely for the prevalence of società per azioni among medium-large firms. There are no significant disadvantages for the società a responsabilità limitata when the company stays private and borrows only from banks. Moreover, creditors and suppliers could "contract" with the company for a satisfactory amount of guarantees regardless of its legal structure. ${ }^{23}$ The taxation of profits, at both the corporate and the individual level, is identical, ${ }^{24}$ and the società per azioni has slightly higher operation costs. ${ }^{25}$ It

20. C.c. art. 2472(2) (taly).

21. C.c. art. 2486(3) (Italy) (no issuance of bonds); art. 18(1), Law of June 7, 1974, No. 216; art. 11 (2-4), Legislative Decree of Sept. 1, 1993, No. 385; and Law of Jan. 13, 1994, No. 43 (no issuance of commercial papers, loan notes, evidences of indebtedness, and no public offerings of debt and equity securities in general).

22. All CONSOB regulations about admission of companies to listing or public trading require the form of the societa per azioni or the societd cooperativa. This is true for the Italian Stock Exchange (infra note 143), for the "Mercato ristretto" [Restricted stock exchange], and for minor stock exchanges, which will take the form of interdealer quotation systems and are expected to start operations soon. See, respectively, the regulation adopted on May 24, 1989, No. 4088 (1989 RIVISTA DELLE SOCIETÀ 538), the regulation adopted on June 30, 1977, No. 233 (1977 RIVISTA DEL JE SOCIETÀ 229), and the regulation adopted on Sept. 30, 1994, No. 8469 (IL SOLE - 24 ORE, Oct. 7, 1994, at 9).

23. The minimum contributed capital of the societd per azioni is 200 million liras (mughly 120,000 U.S. dollars at the prevailing 1995 exchange rate), while that of the società $a$ responsabilità limitata is ten times smaller. See, respectively, C.c. art. 2327 and 2474(1) (Italy). There are no limits, however, to the maximum capital of either kind of company. Nothing, then, prevents creditors from conditioning the financing of a società a responsabilità limitata to the existence of a certain amount of capital.

24. Arts. 87, 91, 116, $118(1), 121$, Legislative Decree of Dec. 22, 1986, No. 917. The normal corporate tax rate is currently $53.2 \%$ (resulting from a $37 \%$ general corporate income tax and a $16.2 \%$ local income tax on capital). Dividends are taxed at the individual level according to the applicable tax bracket (varying approximately from $10 \%$ to $51 \%$, plus another tax between 4.6 and $6.6 \%$, applied as a contribution to the national health care service). Individual shareholders, however, are entitled to offset part of the tax paid at the corporate level against their personal income tax liability. Originally, the whole amount of general corporate income tax (then $36 \%$ ) paid on the amount distributed as dividend could be offset. Today, after an increase of one percentage point in the corporate income tax rate adopted in March 1995 as part of an extraordinary, but not temporary, national budget containment measure, the tax credit does not restore completely the shareholder of the corporate income tax anymore. Of course, shareholders do not receive credit for the income tax the company pays on earnings that are retained. Under art. 4, Law of Aug. 8, 1994, No. 489, individual shareholders of listed companies are entitled to give up the tax credit and to opt instead for a flat tax of $12.5 \%$, which is attractive only for highbracket taxpayers.

The set-off is made acoording to a rather complicated formula: a 1,000-lira dividend gives rise to a taxable income of $1,562.5$ liras, but the shareholder is entitled to a tax credit of 562.5 liras (amounting approximately to the general corporate income tax paid by the corporation); thus, considering the health care service contribution:

- a shareholder whose tax bracket is $10 \%$ actually receives a "dividend" of about 1,300 liras; 
is very likely, then, that intangible but extremely important considerations of "corporate image" come into play in determining the corporate landscape. Companies, as they grow, need to hold themselves out as serious enterprises, and therefore, they need to wear the clothes typical of serious enterprises, i.e., the form of the società per azioni. Everyone with any practical experience knows how serious concerns of this kind are.

Legal and non-legal constraints, thus, render more "costly," in a broad sense, the adoption of the legal structure of the società a responsabilità limitata for medium-large firms. Such firms, then, normally choose the form of the società per azioni. ${ }^{26}$ In the following pages, therefore, we will examine the

- a sharcholder whose tax bracket is $27 \%$ actually receives a "dividend" of about 1,050 liras;

- a shareholder whose tax bracket is $41 \%$ actually receives a "dividend" of about 850 liras;

- a shareholder whose tax bracket is $51 \%$ (at this level of income the health care contribution has reached a ceiling, so that one can assume dividends as subject only to the personal income tax) actually receives a "dividend" of about 750 liras. (Hypotheticals found in IL SOLE - 24 ORE, June 9,1994 , at 3 , and adapted to the increase of one pencentage point in both the corporate tax rate and the national health care service contribution resulting from the mentioned budget measure adopted in March 1995. This measure has obviously reduced the amount of corporate income that goes into, and stays, in the shareholders' pockets.)

25. The call for a shareholders' meeting and a few other operations are more complex and costly in the societd per azioni than in the societd a responsabilita limitata; otherwise, most of the costs are identical, or only slightly lower in the societd a responsabilitd limitata. (A substantial difference in annual corporate franchise tax has been recently eliminated. This difference could account for a part of the past success of the societd a responsabilitd limitata.) The difference is significant, however, for small societd a responsabilita limitata, for which the board of auditors is optional ("small," here, means capital less than 200 million liras and limited business size, as defined in C.c. art. 2435-bis (Italy), to be read in connection with C.c. art. 2488 (Italy)).

26. As of 1993, among the 1,000 largest Italian companies, excluding banks and insurance companies, classified by annual turnover, there were 810 societd per azioni, 116 s.r.l. 37 cooperatives and consortia, two foreign companies, one public entity. Thirty-four companies were reported without indication of the legal form in the name. (Some of which were subsidiaries of large groups). Of the first 100 companies, all but six s.r.l. and seven cooperatives were societc per azioni. More specifically, as of 1992, among the 5,000 largest Italian companies-excluding banks and insurance companies-4,003 were s.p.a., although only a very small part of them (less than five percent) were listed on a stock exchange. Other kinds of companies were distributed as follows, in decreasing size order:

- companies from No. 1 to No. 10 (from 30,008 to 5,311 billion lire turnover): no companies other than s.p.a.;

- companies from No. 11 to No. 100 (from 5,259 to 877 billion lire turnover): four s.r.l. (two of them are operating subsidiaries of an Italian group, one is an operating subsidiary of a foreign group, and one is a holding company of an Italian group);

- companies from No. 101 to No. 500 (876 to 247 billion lire turnover): 47 s.r.l., seven cooperatives (many of the societd a responsabilitd limitata were operating subsidiaries or holdings of large groups);

- companies from No. 501 to No. 1000 (246 to 140 billion lire turnover): 71 s.r.l., 16 cooperatives; 
structure of the società per azioni, giving brief accounts of the peculiarities of the società in accomandita per azioni and the società a responsabilità limitata.

\section{E. The Protagonists of the Governance of the Società per Azioni.}

Power in the società per azioni is allocated among three organs: the shareholders; the board of directors; and the board of auditors. Broadly speaking, shareholders have the power to decide who will manage the company, who will supervise the managers, and they have a voice in certain fundamental decisions. Directors manage the company, and auditors, who are part of the corporate structure, supervise directors in the interests of shareholders and creditors.

- companies from No. 1001 to No. 1500 (140 to 98 billion lire turnover): 77 s.r.l., nine cooperatives;

- companies from No. 1501 to No. 2000 (98 to 76 billion lire tumover): 85 s.r.l., four cooperatives;

- companies from No. 2001 to No. 2500 (76 to 63 billion lire turnover): 109 s.r.l., nine cooperatives;

- companies from No. 2501 to No. 3000 (63 to 54 billion lire turnover): 97 s.r.l., seven cooperatives;

- companies from No. 3001 to No. 3500 (54 to 47 billion lire turnover): 111 s.r.l., one cooperative;

- companies from No. 3501 to No. 4000 (47 to 42 billion lire turnover): 116 s.r.l., four cooperatives;

- companies from No. 4001 to No. 4500 (42 to 37 billion lire turnover): 111 s.r.l., two cooperatives;

- companies from No. 4501 to No. 5000 (37 to 34 billion lire tumover): 104 s.r.l., six cooperatives, one limited partnership.

For banks and insurance companies, moreover, the only legal form presently allowed is the societd per azioni and the societd cooperativa (some non-stock public entities, "grandfathered" by the financial market laws, survive). Again for the fiscal year 1992, out of the 50 largest commercial banks, classified by total assets, 39 were societd per azioni, ten were cooperatives and one ("Monte dei Paschi di Siena," founded in 1472 and the most ancient bank in the world still operating) was a public entity (it became a societd per azioni only in 1995). All the largest 100 insurance companies (with the exception of very few mutual insurances), classified for total amount of premiums, were societd per azioni.

The preceding survey is based on the corporations' names as published in Le prime 5000 società italiane e i 200 gruppi consolidati, Supp. to MONDO ECONOMICO, Dec. 25, 1993, and Le prime 1000 societd italiane e i 200 gruppi consolidati, Supp. to MONDO ECONOMICO, Dec. 31 , 1994. There is a slight margin of error, due to possible errors in reporting. Also, as above noted, a few companies' names were reported without any indication of their legal form, so that it has been impossible to assign such companies to any specific group. The numbers, however, can be considered significant evidence for the predominance of the società per azioni among companies whose total added output was a very substantial part of the Italian GNP in 1992. 


\section{The Shareholders.}

Shareholders in the società per azioni do not have direct power to manage the company. Their fundamental powers consist in electing and removing directors and auditors, ${ }^{27}$ in determining their compensation, in voting on amendments to the charter and by-laws (which include matters such as the issuance of new stock and convertible bonds, mergers, dissolution of the company), in voting on the issuance of bonds, ${ }^{28}$ C.c. art. 2364,2365 (Italy), ${ }^{29}$ and on other subjects. ${ }^{30}$ A key feature of the system is a special power of shareholders over directors' and auditors' liability. This feature will be specially examined throughout this paper: directors and auditors may be held liable only if a majority of the voting shareholders decide to institute action against them. C.c. art. 2393(1) (Italy).

Shareholders act generally as a group, following a call for a meeting. Each shareholder, however, or in certain cases shareholders representing a certain fraction of the capital, have some special rights. These rights include authority

27. See infra note 61 and accompanying text, for a difference between removal of directors and auditors.

28. The issuance of bonds by banks has been permanently assigned to the board of directors by the new banking law, except for bonds convertible in stock of the same bank (art. 12(3), Legislative Decree of Sept. 1, 1993, No. 385).

29. The law requires higher majorities for charter amendments and issuance of bonds. C.c. arts. 2368, 2369, 2369-bis (Italy).

30. One of the most emphasized powers of shareholders is the power to approve the financial statements of the company. The shareholders' role with respect to this matter, however, is ambiguous at best. Financial statements are obviously prepared by the board of directors (C.c. art. 2423(1) (Italy)), which has the relevant information and can make the necessary evaluations. Whether shareholders can only approve or reject financial statements or they can also modify them is a matter of debate. (Compare BERARDino LiBonati, FormazionE DEL. BILANCIO E DESTINAZIONE DEGLI UTLI 33 (1978); FRANCESCO GALGANO, LA SOCIETÀ PER AZIONI 337-38 (2d ed. 1988); FERRARA \& CORSI, supra note 2, at 661-62 (shareholders cannot modify financial statements), with 2 CAMPOBASSO, supra note 2, at 419; DI SABATO, supra note 2, at 592-93; JAEGER \& DENOZZA, supra note 2, at 502-03 (shareholders can modify financial statements)). Moreover, the law makes clear that shareholder approval of financial statements does not constitute a waiver for possible directors' liability (C.c. art. 2434 (Italy)), but it is unclear what happens if shareholders expressly refuse to approve them. See Di SabaTo, supra note 2 at 59293. (My view is that due to the normal coincidence of interests between controlling shareholders and directors, this problem is largely moot, as the scarcity of cases confirms). The meaning of shareholders' approval, then, seems to be limited to the fact that any shareholder, by contesting the validity of the approval, has the right to react against the illegality or the falsity of financial statements, by challenging the approval in court. (Shareholders of companies whose financial reports are mandatorily subject to audit-listed companies and financial intermediaries, principally-can sue only if they possess shares amounting to five percent of the capital or to a total par value of 100 million liras. Art. 6, Legislative Decree of Mar. 31, 1975, No. 136.)

For a complete and detailed list of the subjects on which shareholders can, or must, vote, see 2 CAMPOBASSO, supra note 2, at 288-89, and DI SABATO, supra note 2, at 419-20. 
to provoke inspections by the auditors and by the court ${ }^{31}$ and to request and obtain a call of a shareholders' meeting. ${ }^{32}$ Each shareholder, moreover, has the right to question in court the validity of any shareholders' resolution and to obtain its voidance if it is proven to be against the law or the charter. ${ }^{33}$

Shareholders are not allowed to intrude in the management of the company unless expressly requested to do so by the directors or, ex ante, by the charter. ${ }^{34}$ In no event may they give orders to the directors. ${ }^{35}$ Even so, the amount of power shareholders of Italian companies have, when compared with their American counterparts, can be considered very high. The law prevents a dilution of their voting rights by means of multiple voting shares ${ }^{36}$ and sharply limits departures from the "one share one vote" principle. 37

Shareholders have the final say on fundamental matters like dividend policy and capital structure. They decide what part of the earnings must be paid out to

31. C.c. art. 2408 and art. 2409 (Italy). C.c. art. 2409 (Italy), which is one of the key provisions of the balance of power between majority and minority shareholders (infra note 277 and accompanying text), will be discussed later.

32. C.c. art. 2367 (Italy).

33. C.c. arts. $2373,2377-79$ (Italy). C.c. art. 2373 (Italy) deals specifically with the conflict of interest of one or more voting shareholder (the resolution is voidable if it passed with the decisive vote of interested shareholders and it can harm the corporation), while the other three provisions deal with void or voidable resolutions and with procedural problems.

34. C.c. art. 2364(1), No. 4, (Italy).

35. Judgment of Feb. 7, 1972, No. 296, Cass. civ., 1972 GIUSTIZIA CIVILE I, 688. See also FRANCESCO CORSI, IL CONCETTO DI AMMINISTRAZIONE NEL DIRTTO PRIVATO 267-84 (1974); FrANCO BONELLI, GLI AMMINISTRATORI DI SOCIETÀ PER AZIONI 5-12 (1985); 2 CAMPOBASSO, supra note 2, at 327. According to a different opinion, shareholders' resolutions can be binding for the directors under particular circumstances: VINCENZO CALANDRA BONAURA, GESTIONE DELL'IMPRESA E COMPETENZE DELL'ASSEMBLEA NELLA SOCIETÀ PER AZIONI 159-88 (1985).

36. C.c. art. 2351(3) (Italy).

37. C.c. art. 2351 (2) (Italy). As to voting rights, only three classes of shares can be created: common stock, which votes on every matter, limited-voting preferred stock, which votes only in "extraordinary meetings" (i.e., essentially, on charter amendments and issuance of bonds), and non-voting cumulative preferred stock, which the law defines, a little populistically, as "azioni di risparmio," i.e., savings shares. Three clarifications are necessary:

(1) the total numbers of shares of stock with limited voting rights (i.e., preferred stock and non-voting cumulative preferred stock) can never exceed one-half of the total number of shares outstanding. C.c. art. 2351(2) (Italy);

(2) every charter amendment resulting in the impairment of the rights of one class of stock comparatively to the others must be approved by a majority of shares of the impaired class. C.c. art. 2376 (Italy); on class voting see the unsurpassed study of ARIBERTO MIGNOLI, LE ASSEMBLEE SPECIALI (1960);

(3) only listed companies can issue non-voting cumulative preferred stock. C.c. art. 14-16 (Italy), Law of June 7, 1974, No. 216; See generally MaURIzIo DE ACUTIS, LE AZIONI DI RISPARMIO (1981). The non-voting cumulative preferred stock gives the stockholder an absolute right to the dividend, provided that there are earnings (unlike the limited-voting preferred stock, whose right to dividends is subject to the vote of sharelolders: see infra note 38 and accompanying text); this right, if unsatisfied, is carried over the following years. 
them and what part may be reinvested. ${ }^{38}$ They must approve the issuance of stock, bonds, warrants and convertible bonds, which technically take the form of charter amendments ${ }^{39}$ and may be delegated to the board of directors only for a limited period of time. ${ }^{40}$ Preemptive rights may not be waived by the charter and may be only limited for single issuances, in special circumstances and following an absolute majority vote. ${ }^{41}$

In light of the predominant ownership structure of Italian companies, which we will examine in Part IV, the rather important role of shareholders is hardly surprising. The whole system of corporate governance, and sometimes the very ability of the company to survive, is based on the assumption that a large part of the shareholders will participate actively. ${ }^{42}$ This assumption is basically correct

38. C.c. art. 2433 (Italy). The directors of companies whose financial reports are mandatorily subject to audit (see supra note 30 ) have the power to declare semi-annual advances on dividends. See C.c. art. 2433-bis (Italy).

39. The issuance of bonds is not an amendment of the charter, despite its being subject to identical formalities.

40. Maximum five years. C.c. art. 2420-ter, 2443 (Italy), amended by the Legislative Decree of Feb. 10, 1986, No. 30. Previously the maximum period was one year. Shareholders must also authorize repurchase and resale of the company's shares. C.c. art. 2357 (Italy) (authorization must be detailed and can be given for a maximum period of 18 months). In listed companies, however, this authorization is given routinely and can lawfully be open-ended as to the total number of transactions. Tribunal of Trieste, Judgment of July 3, 1987, 1988 GIUSTIZIA CIVILE I, 2994; 1988 GIURISPRUDENZA COMMERCIALE II, 124.

41. C.c. art. $2441(5)$ (Italy). The majority requirement is reinforced in that, even at a second and third call of the shareholders' meeting, where the number constituting a quorum is lowered (see infra note 42), the approval of more than a half of the total capital is always necessary.

42. Charter amendments are implemented following a resolution approved during a socalled "extraordinary shareholders' meeting." "Extraordinary" means little more than a meeting with stricter voting quorums. Such quorums are set as follows:

At the first call, the approval of more than one-half of the voting shares is necessary. C.c. art 2368 (Italy). At the second call, which may take place after the first call has failed to gather more than a half of the voting shares, the approval of more than one-third of the voting shares is necessary, and of more than one-half for particularly sensitive matters, including the limitation of shareholders' preemptive rights. C.c. arts. 2369, 244l(5) (Italy). At a third call, which may take place only in listed companies and after the second call has failed to gather more than onethird of the voting shares, the approval of more than one-fifth of the voting shares is necessary; this quorum is raised to more than one-third for particularly sensitive matters, and to more than a half for the limitation of shareholders' preemptive rights. C.c. arts. 2369-bis, 2441(5) (Italy).

As illustrated, matters like capital structure are embodied in the charter, and changes in the capital structure are charter amendments, requiring the affirmative vote of a high number of shares. Thus, vote by proxy is very limited (C.c.art. 2372), and vote by mail (apart from an exception, strange and indeed very limited in practice, for the newly privatized companies, introduced by art 5(5), Law of July 30, 1994, No. 474 and implemented with Regulation issued jointly by Bank of Italy, CONSOB and ISVAP on Dec. 30, 1994) is not allowed. It seems reasonable to assume that such high majority requirements have stayed until today because companies are actively followed by large shareholders. See infra Part IV). 
because directors are closely watched by the majority shareholders when they are not the majority shareholders themselves.

As noted earlier, however, Civil Code art. 2393 grants to the shareholders, as a body, absolute authority also over directors' liability: a suit against directors may indeed be maintained only if authorized by a shareholders' vote. This means that the majority of shareholders has the authority to decide whether directors are acting in the interests of the company. Due to the normal coincidence between majority shareholders and directors, this grant of powers seems less obvious and less justifiable. We will come back to this point later.

\section{The Board of Directors.}

All members of the board of directors are elected by the shareholders; any contrary provision is void. ${ }^{43}$ A partial exception to this principle is midstream vacancies owing to resignation or other causes, which can be temporarily filled by the board itself. ${ }^{44}$ While a different rule is permitted, ${ }^{45}$ the default rule is that all the members of the board are elected by the majority. ${ }^{46}$ No representation on the board is thus granted to the minorities only by operation of the law, and charters rarely provide otherwise.

43. Judgment of Jan. 25, 1965, No. 136, Cass. Civ., 1965 Foro italiano I, 427; Judgment of Apr. 17, 1990, No. 3181, Cass. Civ., 1991 Foro rraliano I, 1533; Judgment of Aug. 27, 1969, Appellate Court of Milan, 1970 Giurisprudenza ITAliana 1-2, 546; 2 CAMPOBASSO, supra note 2, at 329 n. 2; BONELLl, supra note 35, at 57 \& n. 13. Compare the different solution in $\$ 8.03$ (b) and (c) of Revised Model Business Corporation Act [hereinafter RMBCA].

A different solution was proposed in the Commercial Code project of 1940 , eventually merged with the Civil Code (supra text acoompanying note 3). Under art. 240 of this project shareholders could elect only half of the board, delegating to the directors the election of the other half. The solution was turned down in the final draft.

The law allows a narrow exception, permitting charter provisions which grant to State or public entities the right to elect some directors, and auditors, of companies in which they have an interest, whether they own stock or not. C.c. arts. 2458-61 (Italy). These provisions have limited practical application for business corporations, while they are often applied for mixed publicprivate consortia set up in the form of societd per azioni.

44. C.c. art. 2386(1) (Italy). When vacancies involve the majority of members of the board, the board cannot fill them and must promptly call a shareholders' meeting to elect new directors. C.c. art. 2386(2) (Italy). See C.c art. 2386(4) (Italy) for other specific cases.

45. C.c. art. 2368(1) (Italy). The last sentence reads: "The charter may establish special rules for the elections of corporate officers." Id. The recent law on privatizations of state-owned companies has mandated list-vote for the election of directors of privatizated companies when the charter imposes a ceiling on the ownership of each shareholder. Art. 4, Law of July 30, 1994, No. 474.

46. As we will see later, the majority is sometimes formed by various shareholders tied by an agreement on the governance of the company. Even when the company lacks an absolute majority shareholder, however, the line between majority and minority remains usually well clear. 
The board is elected for a maximum period of three years. ${ }^{47}$ Although a recent decision has taken a different view, ${ }^{48}$ the default system appears to be the non-staggered board; however, the charter may lawfully provide differently. Directors can be removed by a shareholders' vote at any time, and they are only entitled to damages if the removal is proven to be without cause. ${ }^{49}$

The corporation is governed by a one-level board. The board of directors has all the powers necessary to manage the company, while the supervision of the management is committed to a special body that is independent from the board of directors and lacks any managerial power. The Italian system is, therefore, "monistic,"s0 as opposed to "dualistic" systems like Gemany's, in which day-today operations, on the one hand, and major corporate policy decisions and supervisory activity, on the other, are mandatorily apportioned at two different levels of the same administrative structure.

However, the Italian "monistic" system is very flexible. The directors act collectively as a board, ${ }^{51}$ but the shareholders or the charter may authorize the board to delegate most of its powers to one or more of its members. Powers can be delegated to one or more "delegated directors" who can act alone on specific matters, or to an executive committee of delegated directors who act collectively according to Civil Code Art. 2381. No high-level decisional authority can be granted by the board to non-members. ${ }^{52}$

47. C.c. art. 2383(2) (Italy).

48. Judgment of Mar. 4, 1994, No. 2144, Cass. Civ., 1994 GiurisprudenzA COMMERCIALE $I, 639$. The Court of Cassation has gone against a long-standing (see, e.g., GUSTAVO MINERVINI, GLI AMMINISTRATORI DI SOCIETÀ PER AZIONI 33 (1956)) and almosi uncontested theory, and seems to be contrary to the plain interpretation of C.c. art. 2386 (Italy). See a penetrating critique of the cited decision in Francesco Corsi, Amministratori: avanti in disordine sparso? [Directors: Ahead in Open Disorder?], 1994 GIURISPRUDENZA COMMERCIALE II, 641.

49. C.c. art. 2383(3) (Italy). Cf. infra for the difference between removal of directors and auditors.

50. The Fifth European Directive Proposal on company law, although favoring the first alternative (see the introductory "Whereas"), leaves to State members of the European Union the choice between a menu of two alternatives: the dual board structure, with a management board responsible for the day-to-day operation of the company and a supervisory council responsible for overseeing the management board, and a single board or internal subdivisions of responsibilities.

51. It is also possible to commit the management to a sole director. See, implicitly, C.c. art. 2380(2) (Italy). This kind of managerial structure is clearly suitable only for very small businesses.

52. The decisional level immediately below the board is normally occupied by the "direttori generali," [general managers] full-time, high-level employees in charge of particular sectors of activity such as finance, administration, export, and operations with foreign countries. etc. They are not members of the board, and are, at least as a matter of law, subordinated to it. Their relationship is mostly subject, regarding internal aspects, to the labor law and regarding external aspects (i.e., the existence and limits of the general managers authority to bind the corporation), to the law of general and commercial agency. 
Thus, a double level of management can be, and in medium-large companies usually $i s$, created by the shareholders. ${ }^{53}$ Typically, members of

The relevance of direttori generali for black letter corporate law is limited to Civil Code art. 2396 (Italy), which, in synthesis, states: (a) that the direttori generali can be elected directly by the shareholders (which rarely happens); (b) that their role can be provided for by the charter; (c) that in the preceding two cases, they are subject to the same liability provisions of the directors, as far as their own tasks are concerned. Provided that every employee of the company, under general provisions of the law, can be held liable in connection with possible wrongdoing or fraud, C.c. art. 2396 (Italy), subjecting the liability of direttori generali to the same provisions of directors' liability, in some respects expands that liability (by rendering them directly responsible to creditors, in limited cases) and in some other respects restricts it (by requiring a shareholders' vote to maintain a suit against them). See generally ALESSANDRO BORGIOLI, I DIRETTORI GENERALI DI SOCIETÀ PER AZIONI (1975).

It is disputed whether Civil Code art. 2396 has the effect of strengthening the general principle that directors are entitled to reasonable reliance on subordinates (normally weaker in the Italian corporate law than the model one set forth in $\$ 8.30(\mathrm{~b})$ of the RMBCA) (compare BorGIOLI, supra, at 187, 190 (directors' liability reduced for matters delegated to direttori generali elected under Civil Code art. 2396 (Italy)) with Franco Di Sabato, Sui rapporti fra la responsabilità degli amministratori di s.p.a e quella dei direttori generali, 1985 RASSEGNA DI DIRITTO CIVILE 450 (no differences in liability due to the method of selection)).

53. The delegation of power on the basis of Civil Code art. 2381 addresses only the allocation of internal decisional authority, and has nothing to do with the authority to bind the corporation. The law treats these issues differently. While the charter, the shareholders and the board have a certain leeway in allocating internal decisional authority, the law conclusively resolves most of the questions arising from the existence or absence of authority to bind the corporation.

The law requires that the charter establish clearly and in a general way who has the authority to bind the corporation (e.g., the president of the board of directors, each delegated director, two delegated directors jointly) C.c. art. 2328, No. 9 (taly)). The directors who actually have that authority must deposit their signatures in the "Ufficio del registro delle imprese" [Office of Register of Enterprises]. C.c. art. 2383(4) (Italy). The Register of Enterprises contains an updated version of the charter, the financial statements and other relevant data on listed and unlisted companies. It is accessible to cveryone in person or by on-line service.

Once the compration has been properly represented by the director(s)/officer(s) authorized by the charter, every question of existence of authority is irrelevant for the third party under C.c. art. 2384(2) (Italy) (except in those rare cases in which the third party acted fraudulently). Moreover, C.c. art. 2384-bis (Italy) establishes that the ultra vires defense cannot be used against a third party in good faith, with the company having the burden of proving bad faith. Every violation of the charter or other internal rules will give rise to the liability of the agent, but absent exceptional circumstances, will not affect the third party.

For instance, if the charter gives the president of the company authority to bind the corporation, the party contracting with him can, under C.c. art. 2384(2) (Italy), enforce the contract even if a board's resolution, or the charter itself, requires that kind of contract be authorized by the board. The result is the same, under C.c. art. 2384-bis (Italy), if the company claims that the contract does not serve its business purpose as stated in the charter. As a matter of fact, notwithstanding that Italian law does not allow a general purpose clause like the one allowed by $\$ 3.01$ (a) of the RMBCA, Italian courts are reluctant to allow any kind of ultra vires claims, except in egregious cases in which the bad faith is apparent. (Compare, e.g., Judgment of June 15, 1989, No. 2876, Cass. civ., 1989 MASsimaRIO DEL FORO ITALIANO 424 (remittal of debt 
the executive committee and/or delegated directors are full-time employees of the company, while other directors serve only part-time. We can term the former "inside directors/officers," and the latter "outside directors." 54

The principal duty of directors is to manage the company in the interests of the shareholders. Specific obligations to the creditors, imposed by the general civil law and by some specific provisions, do not create a general duty to act in the creditors' interest. ${ }^{55}$ Moreover, even if a certain amount of charitable contribution is commonly admitted, ${ }^{56}$ a general duty to act in the interest of

without immediate consideration held valid), with Appellate Court of Turin, Judgment of Oct. 18, 1982, 1983 DiRITTO FALLIMENTARE II, 367 (purchase of a racing car by the president of a small cooperative voided).

Both C.c. art. 2384(2) and 2384-bis (Italy) are the result of the implementation, in 1969, of art. 9.1 and 9.2., respectively, of the First European Directive on company law. The goal of the Directive, in this respect, was to protect third parties, then reducing the transaction costs arising from uncertainties concerning the corporate officers' authority to bind the corporation. This approach seems quite straightforward, and seems much more effective than that based on the socalled "cheapest cost avoider," suggested, for instance, by ROBERT C. CLARK, CORPORATE LAW 121 (1986) (otherwise generally oriented toward a broad protection of the third party), and by WILlaM A. KLEIN \& John C. COFFEE, JR., Business ORganization AND FinanCE 133 (5th ed. 1993) (stressing economic efficiency). True, the third party can sometimes easily ascertain the authority of the corporate officer; however, substantial costs arise from the need to repeat the operation for every non-trivial transaction, as well as from the litigation that even the least uncertainty about corporate authority usually sparks when appropriately big interests are at stake.

The choice seems somewhat a policy one. Who should bear the cost of the directors' violation? The European answer is the shareholders, while the American answer varies, depending on the circumstances. Perhaps these different solutions can be seen as a result of the different positions of European and American shareholders: as a matter of fact, European shareholders are typically strong and influential, while their American counterparts are typically "weak" (see ROE, supra note 16, for a thorough analysis of the phenomenon and of its possible economic and political causes). The approach of the American courts may thus be seen as a (weak and probably costly) way of protecting "weak owners" against strong and potentially unaccountable managers.

54. We can also consider "officers" the "direttori generali," described supra note 52 , making it clear, however, that they are always subordinated to the board.

55. See infra note 89 for a discussion of the board's duty to creditors.

56. For an important case involving a listed company, see Tribunal of Perugia, Judgment of Apr. 26, 1993, 1994 FoRO ITALIANO I, 261 (upholding a charter provision mandating some yearly charitable contributions); see generally DISIANO PREITE, LA DESTINAZIONE DEI RISULTATI NEI CONTRATTI ASSOCIATIVI 209-10 (1988) (enhancement of the interests of the shareholders through a reasonable amount of charitable contributions). A corporate charter that states the goal of enhancing interests other than making and distributing money to shareholders is commonly considered void: see GIORgIO MARASÀ, LE SOCIETÀ. SOCIETÀ IN GENERALE, 220-26 (1991). The main argument, which $I$ will not discuss here, justifying this draconian conclusion is the following: limited liability is a privilege that the legal system grants only for limited purposes; different legal structures and different incorporating procedures grant limited liability for nondividend purposes (cooperatives, consortia), or for non-profit purposes (associations, foundations). Therefore, an indirect use of the corporate form is unlawful. 
constituencies other than the shareholders or of the community at large does not exist. $^{57}$

As directors' liability is the main subject of this paper, we will examine it extensively later.

\section{The Board of Auditors.}

The board of auditors, probably the most peculiar aspect of the Italian corporate governance system, is composed of independent professionals entrusted by the shareholders with the supervision of the directors. The manner in which auditors are elected is identical to that of directors: the shareholders elect all the members of the board, and, unless the charter so provides, no representation is granted to the minority.

The board is composed of either three or five members, plus two substitutes for possible vacancies. A recent reform enacted in compliance with the Eighth European directive on company law has tightened requirements for serving on the board, ${ }^{58}$ providing that all members be chosen from the roll of the

57. The problem of the goal of public enterprise is a very difficult one, especially when the public sector has vast proportions, as in Italy. It has long been debated whether the state should use the tool of the società per azioni to achieve its non-economic (or non-purely economic) objectives (see 2 TULLIO ASCARELLI, Tipologia delle società per azioni e disciplina giuridica, in PROBLEMI GIURIDICI 1001, 1019-23 (1959)) (no joint state and private ownership of societa per azioni because they have different goals; the public entity form better suitable for state enterprise). The trend towards the general use of the societd per azioni, however, seems irreversible at the present moment, as hundreds of banks and other enterprises have recently been changed from public entities into societc̀ per azioni (see infra note 192 and accompanying text). For a brilliant assessment of the history of the large public holdings, see Natalino Irti, Dall'ente pubblico economico alla società per azioni (profilo storico-giuridico), 1993 RIVISTA DELLE SOCIETA 465. BONELLI, supra note 35, at 19-21, discusses in detail two cases that occurred some years ago, which well illustrate the conflicts that can arise between economic structure and noneconomic goals.

Ente Nazionale Idrocaurburi, or ENI (public entity-holding, now società per azioni), wanted to force a subsidiary (SNAM s.p.a.) to enter into a transaction with the Algerian Govemment for the supply of natural gas. The transaction was economically unfavorable for the subsidiary, but politically important for the Italian-Algerian relationship. The directors of the subsidiary, claiming that it was not the subsidiary's duty to benefit the country as a whole, asked for, and obtained, relief from the Italian Govemment from losses arising from the contract.

The second case had a different conclusion. The president of Alfa Romeo s.p.a., a large car maker then controlled by Istituto per la Ricostruzione Industriale, or IRI (also a public entityholding that has become societa per azioni), refused to implement a "directive" from the parent entity. The directive, which had clear social, rather than economic, purposes, required Alfa Romeo s.p.a. to build a new plant in the Naples area instead of one close to the existing plants. IRI, availing itself of its powers as majority shareholder (even if in an indirect way), replaced the president of Alfa Romeo.

58. The reform was implemented between 1992 and 1994 (Legislative Decree of Jan. 27, 1992, No. 88, and following regulations of the Minister of Justice). 
"revisori contabili" [auditors]. ${ }^{59}$ The roll is kept under public supervision and lists persons with a significant curriculum of studies in law, business organization and/or accounting, who have proven experience in practice, and who have passed a special examination. Typically, auditors are practicing professionals who serve on the board of more than one company.

The central idea behind the legal structure of the board of auditors is independence. Relatives of the directors and persons who are employees or who are otherwise compensated on a regular basis by the company or by its subsidiaries cannot be elected as auditors. ${ }^{60}$ Auditors serve for a period of three years, and unlike directors, they can be removed exclusively for cause; the shareholders' removal, moreover, takes effect only if approved by the court. ${ }^{61}$ Auditors have fixed compensation and variable risks; their compensation is fixed for the entire period of service and does not depend on the company's performance.

The auditors' duties are basically monitoring directors and acting in the place of the latter if they refuse to follow the rules of corporate governance, or to accomplish specific and legally mandated acts. ${ }^{62}$ It is not the auditors' responsibility to assess the appropriateness of business decisions made by the board of directors. In other words, the auditors' task is to assure compliance with the rules set forth in the law and the charter, not to review the conduct of the board on its merits. ${ }^{63}$

59. C.c. art. 2397 (Italy). Professional qualification was previously required only for part of the members of the board. Unfortunately, the reform has "grandfathered" everyone having served as a member of the board of auditors for a certain amount of time, even if completely unqualified, allowing him or her to continue to serve.

60. Id. art. 2399 (Italy).

61. Id. art. $2400(1-2)$ (Italy).

62. E.g., a mandatory call for shareholders' meeting: see C.c. art. 2406 (Italy). See also the corresponding sanction for its violation set forth by C.c. art. 2632 (Italy).

63. A recent case sent shockwaves through the corporate community. Judgment of May 7, 1993, No. 5263, Cass. Civ., 1994 Foro ITAllano I, 130, found auditors liable for lack of intervention against a series of negligent decisions causing the company to spend a substantial amount of money in partly unauthorized real estate purchases, saying explicitly that it is the auditors' duty to review managerial decisions. The case, however, concemed an easily actectable case of gross negligence, and it is arguable that the duty to review managerial decisions constitutes only dictum.

The dispute about whether auditors must review directors' decisions on their merit is longstanding (see, e.g., Di SABATO, supra note 2, at 504-05, where there are ample citations). However, it is my opinion that the differences are mainly verbal. As noted infra notes 77-78 and acoompanying text, courts hold auditors liable at least for gross negligence in disregarding several "red flags" and do not charge them for not reviewing normal, even if unfortunate, business decisions. Whether this is "merit" or not is an open, but in my view, a non-decisive, question. 
In particular, auditors must (a) meet as a board at least each quarter, and attend the meetings of the shareholders and board of directors; ${ }^{64}$ (b) check regularly the company's books and internal accounting system; ${ }^{65}$ and (c) prepare a report accompanying the annual financial statements, which goes to the shareholders and then, together with the financial statements, is made publicly available. ${ }^{66}$ (The auditors' report must take a position on the fairness of the financial statements with respect to the accounting system and to the financial situation of the company.) Moreover, auditors have a general power to make investigations ${ }^{67}$ and a duty to report to the shareholders irregularities discovered in the management of the business. ${ }^{68}$ They are not, however, mere agents for the shareholders, as they may challenge in court the validity of shareholders' resolutions. ${ }^{69}$

Auditors are liable for their own violations (e.g., revelation of confidential information and insider trading). ${ }^{70}$ More importantly, though, auditors are jointly and severally liable with the directors for the directors' acts or omissions that cause losses to the company or its creditors, ${ }^{71}$ if they could have avoided the losses through diligent behavior and monitoring. ${ }^{72}$ While the first kind of responsibility does not create any particular difficulty, the second can be problematic because it involves a judgment on when an omission has taken place. Therefore, deciding when auditors can be held responsible for directors' conduct may not be simple.

The problem arises because auditors do not have a direct power of intervention. In other words, auditors cannot stand in for unfaithful directors in

64. C.c. arts. 2403-05 (Italy). Failure to attend a shareholders' meeting or two meetings of the board of directors, without justification, causes loss of office. Attendance at the executive committee's meetings is, on the other hand, optional.

65. Auditors can delegate routine accounting controls to assistants, whose work they are responsible for: C.c. art. 2403-bis (Italy), introduced by the reform implemented by Legislative Decree of Jan. 27, 1992, No. 88.

66. The financial statements, with the directors' report [comparable to the Management Discussion \& Analysis: see C.c. art. 2428 (Italy)], is deposited in the Register of Enterprises (C.c. ant. 2435 (Italy)), which is accessible to the public. (See supra note 53 for a brief explanation of the function of the Office.)

67. Auditors have the duty to make investigations when requested by shareholders holding at least five percent of the capital. See C.c. art. 2408(2) (Italy).

68. For an exhaustive list and discussion of auditors' duties see DISABATO, supra note 2, at 501-06.

69. C.c. art. $2377(2)$ (taly).

70. Respectively, C.c art. 2407(1) (Italy) (implicitly), and art. 2, 4, Law of May 17, 1991. No. 157 , on insider trading.

71. See infra Part III for details on the differences between these two kinds of liability. It is also important to note that the procedure for affirming the liability of the directors and auditors to the company and its creditors is the same.

72. C.c. art. 2407(2) (Italy). 
managing the company. ${ }^{73}$ They can, however, ask the court to void the board's resolutions approved with the vote of interested directors. ${ }^{74}$ The auditors can report acts of mismanagement to the shareholders, and they can report criminal activities (embezzlement, frauds perpetrated on creditors, etc.) to criminal prosecutors, who have the means to stop directors. ${ }^{75}$ If the directors do not, auditors must report the company's losses to the shareholders and, in certain cases, can ask the court to appoint a liquidator. ${ }^{76}$ In most cases, the auditors' normal monitoring activity and the threat of their intervention will suffice to instill diligence in the directors.

In deciding on auditors' liability, the courts tend to follow a rule of reason. They normally charge collusive or simply idle auditors with responsibility for

73. They can only accomplish legally mandated acts. See supra note 62 and corresponding text.

74. C.c. ant. 2391(3) (Italy). This provision is clearly defective, as it does not give to one or more shareholders the standing to challenge the resolution, and it does not provide for any remedy against non-collegial decisions (such as transactions implemented by the delegated director or by the sole director of the company).

Courts have found a remedy for the second problem, resorting to the general private law remedy for transactions by an interested agent (C.c. art. 1394 (Italy): a contract by an agent in a conflict of interest with the principal may be avoided when the counterpart actually knew or could have known of the conflict. As for the sole director, see Judgment of June 22, 1990, No. 6278, Cass. Civ., 1990 Giustizia CIVILE I, 2265. As for the delegated director, for the first time before the Court of Cassation, see Judgment of Feb 1, 1992, No. 1089, Cass. Civ., 1992 Foro ITaLiano I, 2139). The first problem, however, is still open, and it is particularly serious given that shareholders as individuals cannot sue directors derivatively. See infra Part III.

It is my opinion that when requested by a shareholder, a court can issue an injunction under art. 700 Code of Civil Procedure (Italy) to prevent the board from implementing a transaction approved by interested directors. (I argue this because of the criminal sanction imposed on directors acting in conflict of interest, C.c. art. 2631 (Italy)). However, such a remedy would apply only ex ante, and could do nothing once the transaction has been implemented. Additionally, equally serious arguments go against granting an injunction under art. 700 Code of Civil Procedure (Italy) in this situation because the standing requirements for filing an injunction tend to overlap with the standing requirements for initiating an ordinary trial, which shareholders, as individuals, lack. Another way to stop the board of directors, more certain but probably less immediate, would be a petition under C.c. art. 2409 (Italy), which we will examine infra note 278 and accompanying text.

75. Criminal laws give prosecutors, duly authorized by an impartial judge, ample powers to prevent criminals from committing further crimes and from carrying already committed crimes to further consequences. It is argued that C.c. art. 2409 (Italy), which gives the prosecutors a civil remedy in case of mismanagement by directors and collusive behavior by auditors, can be triggered also by the auditors themselves, who, in this hypothesis, are not colluding at all. It is clear that a positive solution is preferable. See, implicitly, Gino Cavalli, $I$ sindaci, in 5 TratTAto DELLE SOCIETÀ' PER AZIONI 1, 175 n. 61 (Giovanni E. Colombo \& Giuseppe B. Portale eds., 1988); contra FERRARA \& CORSI, supra note 2, at 601 .

76. C.c. arts. $2446-48,2450$ (Italy). 
directors' egregious violations that easily could have been detected ${ }^{n}$ or for a delay in reporting to shareholders a financial crisis that required their prompt intervention. ${ }^{78}$ In other words, courts charge auditors with having ignored serious, and often multiple, "red flags." The fact that the majority of, or all of, the shareholders were aware of the "red flags" is not deemed a valid defense."

There is a risk, however, that the auditors can become scapegoats for the losses of insolvent companies. Most liability suits against directors and auditors are instituted by bankruptcy trustees who want to enrich the estate by trying to involve auditors, often professionals with deep pockets or insurance. ${ }^{80}$ It is up to the courts to discourage this type of action. Courts seem to strike an appropriate balance when they dismiss charges against auditors that diligently fulfilled their

77. Judgment of May 7, 1993, No. 5263, Cass. Civ., 1994 Foro Italiano I, 130 (involving no intervention against a series of grossly negligent and unlawful acts causing the company heavy losses; the significance of the case is discussed supra note 63); Judgment of Oct. 9, 1986, No. 5928, Cass. Civ., 1986 LE SOCIETȦ, 1314 (causation found in the failure to control the accounting system and detect clear embezzlements); Judgment of Oct. 13, 1988. Tribunal of

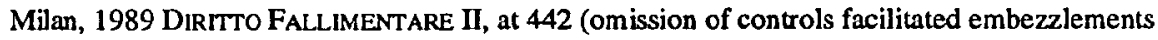
by the directors).

78. Judgment of Apr. 4, 1977, No. 1281, Cass. Civ., 1977 GiurisprudenzA COMMERCIALE II, 449 (failure to control the financial situation and the accounting system of the company allowed directors to keep on running it, thus aggravating the crisis); Judgment of Mar. 28, 1980, Appellate Court of Milan, 1982 GIURISPRUDENZA ITALIANA I-2, 219; Judgment of Jan. 24, 1983, Tribunal of Milan, 1983 IL FALLIMENTo 811.

79. Cavalli, supra note 75 , at 175 \& n. 59; less clear GUIDO UBERTO TEDESCHI, IL COLLEGIO SINDACALE 382 (1992). Same result when directors and shareholders physically coincide: Cavalli, supra, at 175 n. 60; Judgment of Oct. 16, 1959, No. 2886, Cass. civ., 1959 DiRITTO FALLIMENTARE $\Pi, 913$ (the statement is dictum, however); Judgment of July 9, 1975. Appellate Court of Turin, 1976 GIURISPRUDENZA COMMERCIALE II, 871.

There may be two reasons for this seeming severity, one dictated by pure law and the other by policy considerations. On the one hand, the violations and/or the delay in reporting a crisis may cause harm to both shareholders and creditors, who might not have dealt with the company had they known its situation. Most of the actions against auditors are brought in bankruptcy, where both the rights of the shareholders and of the creditors are asserted. On the other hand, courts probably perceive the danger of a defense resting on the shareholders participation in the fraud.

80. GALGANO, supra note 30 , at $314 \mathrm{n}$. 14 (noting the widespread diffusion of insurance policies covering the liability incurred by professionals serving as auditors, and suggests the possibility of voiding that part of the coverage because of its ability to reduce professionals' incentive to monitor effectively). The conclusion is certainly too broad and must be balanced against the risk of discouraging the best professionals to serve as auditors. See, in the United States, the debate and the legislative changes following Smith v. Van Gorkom, 488 A.2d 858 (Del. 1985). Moreover, it is clear that the possibility of reputational harm deriving from an adverse judgment contributes to keeping auditors alert. 
duties $^{81}$ or were unable to detect skillfully concealed directors' acts of mismanagement or misappropriation. ${ }^{82}$

It is difficult to assess whether the board of auditors is an effective institution. The answer probably varies with the size of the company. It is clear that a handful of part-time professionals alone cannot assure airtight monitoring in very large companies. ${ }^{83}$ It is far less clear that they are completely ineffective. ${ }^{84}$ Moreover, in small-medium companies, where they may have a less serious informational disadvantage vis-à-vis directors than in large ones, their goals seem reasonably achievable.

An assessment of past cases alone is not sufficient. First, the qualifications for serving on the board of auditors is now more stringent than before the reform of 1992. Therefore, the only cases giving an insight into the future are those involving auditors with a professional training comparable to that required today. Second, the cases tell what has happened notwithstanding auditors but do not tell what could have happened without them.

On the one hand, auditors are perceived as risk-averse monitors. They have nothing to gain, at least immediately, from loosening the standards of control, nor do they have something to lose from exerting control properly. ${ }^{85}$ Besides, the auditors' risk-aversion does not seem to discourage a healthy dose of risk-taking by the directors, as the former have no power of intervention in "normal" (i.e., not tainted with conflict of interest) business decisions taken by the latter. Finally, when the lines between "normal" and "abnormal" business decisions are blurred, (e.g., because directors are effectively concealing self-interest or fraud), courts seem willing to forgive auditors in good faith.

On the other hand, the institution of the board of auditors suffers from a fundamental ambiguity: the same constituency with the same majority elects the

81. Judgment of July 15, 1982, Tribunal of Milan, 1983 LE SOCIETȦ 1016; TEDESCHI, supra note 79 , at 382.

82. Judgment of Nov. 15, 1960, No. 3056, Cass. civ., 1961 Foro italiano I, 253; Judgment of Dec. 9, 1981, Appellate Court of Palermo, 1982 FALLIMENTO 248; Judgment of Jan. 19, 1974, Tribunal of Milan, 1974 GIURISPRUdENZA COMMERCIALE II, 174.

83. Remember that the 1992 reform found a partial remedy, allowing auditors to delegate most of the accounting controls to assistants. C.c. art. 2403-bis (Italy). Moreover, in listed companies some of the tasks and responsibilities of the board of auditors are taken over by an accounting firm (typically, one of the Italian affiliates of the big American accounting firms), appointed by the company for a period of three years (Legislative Decree of Mar. 31, 1975, No. 136).

84. The board of auditors is said to be "scarcely effective" by GaLGANO, supra note 30 , at 312 .

85. Auditors' compensation is fixed and their tenure is assured, at least until the end of their term. Of course, there is a risk that they will take into consideration the possibility of not being re-elected. 
directors and their guardians. The system seems to protect all the shareholders against managers' shirking or lack of due care, but not minority shareholders' against abuses committed by the directors in the interests of the majority ${ }^{86}$

In light of the particular, highly-concentrated ownership structure of Italian firms, the issue of remedies against the majority's conflict of interest with the minority, or the lack thereof, stands out as the single most important problem of Italian corporate law. After a synthesis of the conclusions reached so far, we will examine the directors' liability system in detail.

\section{F. Summary of Part II.}

Based on the legal system, the following conclusions concerning the respective roles of shareholders, board of directors and board of auditors can be inferred.

A. Shareholders.

A.1. Shareholders possess powerful tools of corporate governance. Essentially they possess the right to vote on capital structure, on dividend policy and on fundamental changes such as mergers. Normally, however, shareholders' powers consist of the right to veto the board's actions rather than the right to impose such actions.

A.2. Shareholders' powers are primarily in the hands of the majority. In other words, majority rule normally governs the way in which shareholders express their voice, while single shareholders have very limited powers. The directors' liability rules, which we will examine next, confirm this conclusion.

B. Board of directors.

B.1. The board of directors has all the powers not expressly reserved to the shareholders. No formal separation between managerial and supervisory activity exists at the board level.

B.2. The board of directors, however, has a flexible structure that allows a delegation of day-to-day operations and substantial decisional authority to a part of its members. Non-delegated members still retain authority to intervene in every decision. A separation between directors in charge of day-to-day operations and directors in charge of supervision exists in every medium-large company.

C. Board of auditors.

C.1. The board of auditors is formally charged with supervision over the administration of the company. Aside from the case of directors' conflict of interest, the board of auditors has no direct intervention or veto power over directors' decisions. However, it has an effective, even if indirect, means of

86. As for the procedural requirements, auditors are liable on the same grounds as directors only if the shareholders, following a majority vote, authorize the suit. See infra note 110 and accompanying text. 
preventing directors from committing unlawful acts. The board of auditors is not charged with the duty to review directors' business decisions on their merits.

C.2. The board of auditors is normally elected by the majority of shareholders, i.e., by the same group that elects directors. Yet auditors, once elected, are relatively independent of shareholders and can challenge their resolutions, if invalid, in court. Moreover, auditors are normally interested in preserving their reputation and are risk-averse monitors as evidenced by the fact that their compensation does not depend on the performance of the company. Whether the board of auditors is an effective institution is an open question. ${ }^{87}$

\section{THE System OF CORPORATE DiRECTORS' LIABILITY: THE LAW}

\section{A. The "Tortious Interference" Liability of Directors to Creditors.}

The system of corporate directors' liability is entirely consistent with the assumption that the key to Italian corporate governance structure lies in the tight relationship between directors and majority shareholders.

Directors can be liable (a) to the company (Civil Code art. 2392, 2393 (Italy)), (b) to its creditors (Civil Code art. 2394 (Italy)), and (c) to shareholders and third parties in general (Civil Code art. 2043, 2395 (Italy)). These different kinds of liability rest on different grounds. While the first is a consequence of directors' obligation to serve the company, the second and third derive from

87. As promised supra, it is now time to keep pace with the differences between societa per azioni and societd a responsabilitd limitata. As for the corporate governance structure, the most significant differences are the following:

(1) the institution of the board of auditors is mandatory only when the company has at least 200 million liras of stated capital or its activity is not minimal in size (i.e., when the company has for two consecutive years been meeting two of the following requirements: (a) total assets more than 3,090 million liras; (b) tumover more than 6,180 million liras; or (c) an average of more than 50 employees each year. C.c. arts. 2435, 2488 (Italy));

(2) when the board of auditors has not been instituted, each shareholder has inquiry and control powers, and shareholders representing one-third of the capital may perform an annual accounting control. C.c. art. 2489 (Italy);

(3) the default (but widely opted-out) rule is that only shareholders can be elected directors. Directors can serve indefinitely (i.e., an expiration date is not mandated as it is in the s.p.a.), but a shareholders' vote can always remove them; and

(4) the societa a responsabilita limitata is the only kind of corporation that can be incorporated by a sole shareholder and is the sole kind of corporation that allows a sole sharcholder to enjoy limited liability (C.c. arts. 2475(3), 2475-bis, 2497(2) (Italy)), provided that the shareholder is not an entity having legal personality and that certain other conditions are met. (The societd per azioni can have a sole shareholder only once it has been incorporated, and in this case the sole shareholder is liable for the obligations of the company when some further conditions, set forth by C.c. art. 2362 (Italy), are met.) No significant changes occur when the societd a responsabilità limitata has a sole shareholder, except that the transactions between the shareholder and the company must always be done in writing (C.c. art. 2490-bis (Italy)). 
general principles of tort law. Putting aside directors' liability to the company for later examination, let us now deal with the other two kinds of liability briefly.

Directors, under the Civil Code art. 2394 (Italy), are liable to creditors when the assets of the company are insufficient to satisfy its obligations and directors have violated the "rules of preservation of the company's assets" (e.g., they have distributed or wasted assets, or they have paid out more dividends than they were allowed). ${ }^{88}$ This provision does not create a duty of the board owed to creditors of the company, but only imposes upon it a duty to abstain from prejudicing the relationship between the company and its creditors. ${ }^{89}$ The most convincing theory, then, seems to be that which describes this provision as codifying a tort-of-interference liability. ${ }^{90-91}$

88. C.c. art. 2394 (Italy) does not only concern illegal payment of dividends but also illegal repurchase of shares, stock watering, and in general every operation that has the effect of reducing the company's assets in violation of a specific provision of law. A strict causation between the operation and the insufficiency of the assets is usually not required. For example, an illegal payment of dividends can be attacked even if the company became insolvent at a later date.

89. It is interesting to discuss the possible outcome of the famous case Credit Lyonnais Bank, Nederland v. Pathe Communication Corporation, No. 12150, 1991 W.L. 277613 (Del. Ch. Dec. 30, 1991) under the Italian law. The case has stirred debate on whether the board of directors owes duties to the creditors of the company, and Chancellor Allen answered that, "[a]t least where a corporation is operating in the vicinity of insolvency, a board of directors is not merely the agent for the residual risk bearers, but owes a duty to the corporate enterprise." Id. at 28 . The board, then, cannot engage in overly speculative undertakings when the company is nearly insolvent. (A possible, more narrow reading of the case is that the board is not liable to the shareholders if it does not engage in speculative undertakings which may have a positive net present value for them but not for creditors: John C. Coffee, Jr., Corporations course, Columbia University School of Law, New York (Jan. 19, 1995).)

One of the criminal provisions accompanying the Italian bankruptcy law punishes directors who wasted a substantial part of the company's assets in "operations of mere chance or [ones which were] clearly imprudent" (art. 217, 224, Royal Decree of Mar. 16, No. 267). No one has ever read such provision as imposing an affirmative duty towards creditors. Actually, much of the debate following the Credit Lyonnais Bank, Nederland v. Pathe Communication Corporation opinion, which pigeon-holed the case as one about the "social responsibility" of the corporation, greatly exaggerated its importance. Are we really to think that the duty of a board of a nearly insolvent company to abstain from operations of pure chance is the consequence of its responsibility towards to the society at large? Or, instead, should we distinguish a non-existing duty to "benefit" creditors, which would prevent the board from taking any risk, from a simple duty not to impose avoidable and clearly unforseeable losses on the creditors?

Probably art. 2394 of the Italian Civil Code represents a reasonable compromise. Taken alone, it is more a "manifesto" provision than a provision frequently enforced and belongs clearly to the field of tort law, rather than to the field of the board's fiduciary duties. Moreover, it saves ransaction costs, as creditors are granted a basic protection by default and do not need to resort to negotiation (which they are obviously free to do if, as can often be the case, the importance of the transaction commands higher and more specified standards of board conduct).

90. To be precise, the nature of the directors' liability to creditors has been discussed. A well-articulated theory asserts its contract-like nature, FRANCO BONELLI, LA RESPONSABILITÀ DEGLI AMMINISTRATORI DI SOCIETÀ PER AZIONI 187-89 (1992) (C.c. art. 2394 (Italy) sanctions a violation of specific duties to protect the interests of creditors). This construction, however 
Creditors can sue directors under the Civil Code art. 2394 (Italy) directly, except when the company is in bankruptcy. In this case the trustee has standing to sue directors in the place of the individual creditors, and the recovery flows into the estate. ${ }^{2}$

\section{B. The General Tort Law Liability of Directors to Shareholders and Third Parties.}

Directors, according to general tort law principles, are also liable to shareholders or third parties they directly prejudiced while exercising their office (Civil Code art. 2043 (Italy), implicitly recalled by Civil Code art. 2395 (Italy)). Typical examples of such liability are the violation of preemptive rights, or misstatements on the financial condition of the company in connection with the purchase or sale of shares ${ }^{93}$ or with the extension of credit to the company. ${ }^{94}$

appealing, is not fully convincing; directors do not personally owe a duty to creditors, which would be required had this obligation been contractual in nature. The clearest reading of C.c. art. 2394 (Italy) as curbing "tortious interference" is in GALGANO, supra note 30, at 298.

The practical consequences of the dispute, however, are not really relevant. Courts do not require evidence of intent or negligence to be offered by creditors. More precisely, once it is established that directors violated their specific obligations toward the company, courts consider intent or negligence with respect to creditors irrelevant. Moreover, for this kind of obligation the statute of limitations is established directly by law. C.c. art. 2949(2) (Italy). Normally, the statute of limitation for obligations arising from a specific duty-improperly called "contractual obligation"-is 10 years, while that for tort obligations is five years).

91. For a particular hypothesis concerning directors' liability for continuing operations while the company is in a (qualified) economic crisis, see infra note 101.

92. It remains unsettled whether creditors lose standing to sue directors in case of concordato preventivo [judicial procedure for insolvent enterprises that the debtor, with the consent of a quorum of creditors, may elect as an alternative to bankruptcy: art. 160 to 184, Royal Decree of Mar. 16, No. 267]: see Judgment of Jan. 14, 1992, Appellate Court of Milan, 1993 GIURISPRUDENZA COMMERCIALE II, 63, and the following note by Simone Borella (creditors' action can be maintained after the judicial approval of the concordato preventivo).

93. In Italy, most of the securities frauds covered by Rule 10b-5 and 14a-9 under the Securities Exchange Act of 1934 would fall under general criminal and tort law (or contract law, if the parties are in privity of contract). Others would fall under the law on insider trading (Law of May 17, 1991, No. 157). Two interesting cases recognized standing to sue to shareholders of two large private banks that collapsed amid probes of fraud perpetrated by their presidents and other managers, on the basis that shareholders would have sold the shares had the financial statement not been falsified, i.e., a non-sale of securities (Order of Jan. 24, 1983, Tribunal of Milan, 1984 GIURISPRUdENZA COMMERCIALE II, 42; Order of Sept. 29, 1983, Tribunal of Milan, 1984 ForO ITALIANO I, 202, 1984 GIURISPRUDENZA COMMERCIALE II, 42). A complete comparison of the two systems, although interesting, exceeds the scope of this research and will not be attempted.

94. For an exhaustive analysis of most of the cases arising under C.c. art. 2395 (Italy) see BONELLI, supra note 90 , at $198-205 \& \mathrm{nn} .98-103$. A special provision, enacted as part of the reform of 1991 implementing the Third and Sixth European Directives on mergers and divisions 
The requirement that the prejudice be "directly" caused by the directors, expressly stated by Civil Code art. 2395 (Italy), is commonly intended to preclude a direct suit for damages against directors, brought by shareholders alleging the loss of value of the stock due to directors' mismanagement or fraudulent practice; such injury is indeed the consequence of the injury to the company, and therefore does not "directly" affect shareholders. Besides, shareholders cannot sue directors derivatively, i.e., on behalf of the corporation, ${ }^{95}$ because no such provision exists.

The system of corporate governance, apparently neutral so far, begins to appear biased in favor of directors. It can be argued that general tort law (Civil Code art. 2043 (Italy)) ${ }^{96}$ would allow a shareholder to recover damages resulting from the loss of value of the stock; if that is so, art. 2395, far from allowing recovery for "direct" damages, precludes it for "indirect" ones. Moreover, the absence of a shareholders' derivative remedy in the Italian legal system, which progressively admits derivative suits as a general remedy for creditors, seems the product of a clear political choice. ${ }^{97}$

The barrier created by the law against shareholders' suits for directors' mismanagement or fraud is in fact not a result arrived at by chance; to the

(splitting) of companies, expressly provides for the liability (also) of directors arising from the merger or division (C.c art. 2504(2) (Italy), recalled by C.c. art. 2504-novies(4) (Italy) for divisions). This liability, even if somewhat peculiar (it indeed can be used as a form of "appraisal remedy"), appears to be tort-like in nature and similar to that provided for by C.c. art. 2395 (Italy) (Alberto Picciau, Osservazioni alle istruzioni del Tribunale di Milano per le omologazioni in materia di fusione, 1991 GIURISPRUDENZA ITALIANA IV, 496, 510; Carlo Angelici, La nullità della fusione, 1992 RIVISTA DEL DIRITTO COMMERCIALE I, 267, 272; Lorenzo Stanghellini, Osservazioni in materia di sindacabilità del rapporto di cambio nella fusione dopo la riforma del 1991, 1995 GIURISPRUDENZA COMMERCIALE II, 127.

95. For the distinction between "direct" and "derivative" suits see CLARK, supra note 53, at 662-64 (suit is derivative "when the wrong complained of primarily constituted an injury to the corporation"; it is direct "when the injury was primarily to the shareholder(s) as such"); JESSE H. ChOPER, JoHN C. COFFE,, JR., \& C. ROBERT MoRRIS, JR., CASES AND Materials on CORPORATIONS 867-68 (1989) (direct suit when the plaintiff has been injured and has a cause of action, and the corporation is a real defendant; derivative suit when the corporation has been injured and has a cause of action and therefore it is only a nominal defendant).

96. "Any act, intentionally or negligently committed, causing damages to a third party, binds its author to indemnify the injured person for such damages." For a fascinating history of the evolution of the case law under C.c. art. 2043 (Italy) from 1942 to date see 3 BIGLIAZZI GERI ET AL., supra note 7, at 671-93.

97. C.c. art. 2900 (Italy) generally allows creditors to bring a derivative action to enforce debtor's rights that he neglects enforcing. The debtor is called upon as a nominal defendant. Moreover, by imposing on directors liability to the creditors of the corporation, C.c. art. 2394 (Italy) itself, examined supra, is derivative in nature (Judgment of Dec. 14, 1991, No. 13498, Cass. civ., 1992 Foro ITALIANO I, 1803).

This does not mean that shareholders should be considered like creditors; it only means that the absence of a derivative remedy seems particularly striking, and not fortuitous, in a system so attentive to protecting rights when enforcement depends on some action by the debtor. 
contrary, legislative history demonstrates that this was precisely what legislators wanted to achieve. ${ }^{98}$ This introduces the central topic of this paper: the liability of directors to the company.

\section{The Liability of Directors to the Company.}

\section{The Grounds.}

Directors must manage a company with the diligence of a prudent person. ${ }^{99}$ The law does not explicitly impose a duty of diligence and a duty of good faith, but both are obviously considered by the courts. Cases concerning directors' liability can be classified as follows: ${ }^{100}$

(a) Cases finding that directors violated specific duties, set by the law or the charter. Here the courts often impose liability for the damages actually derived from the violations, under a quasi-per se rule. ${ }^{101}$

98. This can be read between the lines of the Official Report of the Minister of Justice on the Civil Code, $\$ \$ 172-74$ (see infra paragraph V.C.).

The preclusion of shareholders' direct suits against directors goes back to the Second Code of Commerce of 1882. An influential author of the time, approving such preclusion, described deplorable maneuvers and settlements of "strike suits" in the years before the reform, having both the effect of discouraging good directors and of allowing the recovery to flow directly into the pocket of shareholders (it is the same problem examined by Keenan v. Eshleman, 194 A. 40 (Del. Ch. 1937), aff'd 2 A.2d 904 (Del. 1938)): 2 Cesare Vivante, Trattato di DiritTo COMMERCIALE $471-72$ (4th ed. 1912).

99. C.c. art. 2392(1) (Italy), remanding to C.c. art. 1710 (Italy). The Civil Code pays tribute to the Roman tradition in adopting the standard of the "good father of a family" ("bonus paterfamilias"). Apart from sexist concerns, totally absent when the Civil Code was enacted, courts have sometimes tried expressly to correct the standard, resorting to that of a normally skilled entrepreneur, mindful of the complexity of business management (Judgment of June 26, 1989. Tribunal of Milan, 1990 GuRISPRUDENZA COMMERCIALE II, 122). Implicitly, however, they have always adopted it, by refusing to consider ignorance of business and corporate law a valid excuse from liability (even criminal liability, in the case of bankruptcy). On the problem of judicial evolution, or lack thereof, of the Civil Code standard see Alessandro Arrigoni, La responsabilità sociale degli amministratori tra regole e principi, 1990 GIURISPRUDENZA COMMERCIALE II, 122 (note to Tribunal of Milan, Judgment of June 26, 1989).

100. BONEU, supra note 90 , at 10-109 (valuable and careful review of virtually all cases concerning directors' liability from 1942 to date).

101. Typical examples are falsification of book entries or the preparation of financial statements in violation of the law or the accounting principles, first steps of a pattern usually ending in bankruptcy. If the amount of assets falls below the amount of liabilities (or if the difference is positive, but less than two-thirds of the capital stated in the charter and less than 200 million liras), directors cannot start new operations and are required to call a shareholders' meeting (Civil Code art. 2447 (Italy)). If they instead keep on assuming new risks, they become jointly and severally liable for them (both toward the company and the contracting parties) (C.c. art. 2449 (Italy)). Often directors, for reasons of negligence or worse, omit disclosing the financial crisis or take steps to positively conceal it. 
(b) Cases finding that directors acted negligently. Such cases are not very common: courts usually affirm their willingness not to interfere in business decisions, even though they have not developed a complete and consciously applied "business judgment rule." 102 When the courts do find directors liable, it is often possible to read some kind of interested directors' conduct between the lines, which the plaintiff has been unable to establish with absolute certainty. ${ }^{103}$

(c) Cases finding that directors acted in conflict of interest with the company. In these cases, the courts and, in some circumstances, the law itself impose strict liability for the resulting damages, if any. ${ }^{104}$ Such cases are an overwhelming majority of the total: some of them deal with borderline questions (e.g., parent-subsidiary relationship, corporate group policy), ${ }^{105}$ most of them

102. I dissent in part from BONELLI, supra note 90 , at $63-66$ \& n.117. Italian courts, whether right or wrong, usually stress only their refusal to substitute their judgment for the directors' as to the result; they do not insist, as a precondition to granting immunity, on the procedural aspects through which the business decision has been reached (procedural aspects found relevant in Smith v. Van Gorkom, 488 A.2d 858 (Del. 1985)).

103. Acoording to the study by FRANCO BONELLI, La responsabilita degli amministratori, in 4 TRATTATO DElle SOCIETÀ PER AZIONI 321, 357-58 (Giovanni E. Colombo \& Giuseppe B. Portale eds., 1991), from the enactment of the Civil Code to the end of the 1980s, only in a handful of published cases have directors been held liable on pure negligence counts; interestingly enough, CLARK, supra note 53, at 126, notes that "[n] ot infrequently, the facts suggest that the directors were actually being sued and held liable because of wrongful self-interested conduct - for a violation of their fiduciary duty of loyalty - and the courts' talk about duty of care is simply a way of letting the plaintiffs win without having to prove all the elements of a wrongful conflict of interests transaction."

104. The relationship between the directors and the company (that, mindful of the many differences between the Italian and the American legal systems, we will call a principal-agent relationship for the sake of simplicity), is governed partly by the general contract law and partly by specific corporate law provisions. More particularly, the former applies when the agent is a single individual (sole or delegated director), the latter when there is a collective decision and a resulting problem of quorum. (This does not mean that the resulting system is absolutely consistent or completely effective. For a critique of C.c. art. 2391 (Italy) see supra note 74.)

Under C.c. art. 1394 and art. 1218 (Italy), general contract law provisions, the principal has the right to avoid agent's self-dealing transactions and the right to be indemnified by him for the suffered losses. Under C.c. art. 2391 (Italy), especially concemed with the societd per azioni, disinterested directors and auditors have the right to avoid a board's resolution adopted with the decisive vote of interested directors. Independently from the avoidance of the resolution, the interested directors are automatically liable for the losses derived from such resolution (C.c. art. 2391(2) (Italy)).

105. See generally Agostino Gambino, Responsabilità amministrativa nei gruppi societari, 1993 GIURISPRUDENZA COMMERCIALE I, 841; Francesco Galgano, Il punto sulla giurisprudenza in materia di gruppi di societa, 1991 CONTRATTO E IMPRESA 897; BONELLI, supra note 90, at 95 106; Judgment of Sept. 14, 1976, No. 3150, Cass. civ., 1977 FORO ITALIANO I, 1998. The problem of comprate groups, not only under the profile of directors' liability, has been dealt with in a number of recent cases. Among the most interesting, see Judgment of Feb. 26, 1990, No. 1439, Cass. civ., 1990 Foro ITALIANO 1, 1174; Judgment of Feb. 13, 1992, No. 1759, Cass. civ., 1992 LE SOCIET $\dot{A}^{\prime} 794$ (the best interests of a subsidiary must be judged with respect to the whole group policy and not with respect to the single act); Judgment of May 8, 1991, No. 5123, Cass. 
with outright fraud. As we are more interested in a corporate governance perspective, we will not examine those cases in detail.

\section{The Procedure.}

A suit against directors on behalf of the company can be instituted in three cases:

(a) when shareholders, with a majority vote, have authorized it (Civil Code art. 2393(1) (Italy)); in this case the action is brought by the new directors or by an especially appointed agent for the company;

(b) when the court, requested by a quorum of shareholders or by the public prosecutor, ${ }^{106}$ has ordered an investigation and, serious irregularities having been found, has appointed a temporary administrator (Civil Code art. 2409 (Italy)); the administrator has the power to bring a suit against directors;

(c) when the company is bankrupt; in such case the action is brought by the trustee, ${ }^{107}$ authorized by the bankruptcy judge (art. 146, Royal Decree of Mar. 16, 1942, No. 267)..$^{108}$

From a corporate governance standpoint, the difference among these three hypotheses is apparent: while the second and third do not require the consensus of the majority of shareholders, the first does.

This may have important consequences. As paragraph V.A. will show, an overwhelming majority of the actions against directors is brought by bankruptcy trustees. Actions brought by companies in an ordinary situation following a vote by the majority of shareholders are very rare and so are actions brought under Civil Code art. 2409 (Italy) by administrators appointed by the court. Leaving for further consideration this last hypothesis (infra note 278 and accompanying text), several explanations for the asymmetric distribution of liability actions brought by the majority of shareholders and by bankruptcy trustees can be offered.

civ., 1991 LE SOCIETÀ 1349 (narrowing the broad statements of the preceding cases, in a fact pattern where it was probably not strictly necessary).

106. The procedure has wider legal grounds for listed companies and standing requirements for large groups with insolvent companies (see FERRARA \& CORSI, supra note 2, at 605 ), and is inapplicable to banks, where its place is taken by a procedure aiming at an intervention by the Bank of Italy (art. 70(7) Legislative Decree of Sept. 1, 1993, No. 385).

107. The trustee acts also on behalf of creditors, who lose individual standing (see supra note 92 and accompanying text).

108. Special insolvency procedures for particular kinds of companies provide for an action identical in structure: e.g., the action is brought by the appointed commissioner during the forced administrative liquidation procedure, authorized by the supervising administrative agency (art. 206, Royal Decree of Mar. 16, No. 267; for banks, art. 84(5), Legislative Decree of Sept. 1, 1993. No. 385, authorization by the Bank of Italy), and by the administrator during the special reorganization procedure for large enterprises (art. 3(6), Law of Apr. 3, 1979, No. 95) (for some other cases and more details, see BONELLI, supra note 90 , at 174-76). 
First, it is a common experience that bankruptcy trustees often look for expedients to increase the value of the estate, and courts tend to be sympathetic to trustees. ${ }^{109}$ The higher number of suits against directors of bankrupt companies can therefore be explained as the product of abnormal judicial pressure against directors in such a setting.

Second, it is much more likely that previous mistakes or wrongdoings are found in the pre-bankruptcy management of bankrupt companies because such actions tend to result in the company's insolvency more than normal managerial action does. The higher number of suits against directors of bankrupt companies can therefore be seen simply as a judicial reaction to illegal actions that lead a company into bankruptcy.

The first explanation assumes an abnormal distribution of judicial reactions, the second an abnormal distribution of starting points with which courts deal in a neutral way. Both explanations are probably true, but not exhaustive; in my opinion, a third possibility exists.

As previously discussed, to bring an action against directors, a majority vote by shareholders is necessary. No conclusion can therefore be drawn from a simple analysis of the actions actually instituted without at least taking into consideration the possible number of actions that the majority has stopped. In other words, a correct statistic should include both liability suits which were actually brought and those which were not. Unfortunately, published court reporters give accounts of the former, but not of the latter.

An indirect method can be used to second-guess the system of directors' liability without a majority vote requirement, however. We should look for cases that show an attempt to reach the same goal: to put pressure on the majority and on directors for some kind of alleged wrongdoing. Among these cases, we should try to spot those which, absent the majority vote requirement, would most likely have concerned a minority suit against directors.

At that point, the corporate governance picture could be considered almost complete. If cases showing a tension between the majority's and minority's dealing with management's choices are found, it will be clear that the law shields not the directors as such, but the directors as agents for the majority: given that

109. I could cite scores of cases where courts appeared to be biased in favor of the trustees in bankruptcy (see, e.g., the unmotivated reasoning of Judgment of July 25, 1987, No. 6467, Cass. civ., 1987 IL FALLIMENTO, 1246) (a particular kind of bank operation can be avoided when made within two years before the declaration of bankruptcy, instead of one year, because it is "essentially" an anoumalous form of payment and falls under the discipline of anomaious payments), or the fuzzy logic of Judgment of Dec. 10, 1992, No. 13095, Cass. civ., 1993 Foro TALIANO I, 3100 (the shareholder of a company which later went bankrupt is not entitled to offset a debt for purchase of shares with a preexisting debt owed by the company to him "because the stated capital is the exterior image of the company")). The critique of such a form of bias has long been made (see, e.g., FrancEsco FerRara, IL FALLIMENTo, v (1st ed. 1959)), and this is not the right place to continue it. 
the majority is allowed to bring a suit, directors are protected only against the minority. As suits against auditors are subject to the same procedural requirements, ${ }^{110}$ they too will fit into the picture as part of the game between the majority and minority.

After a second series of provisional conclusions (the paragraph that follows), in the next part we will examine the structure of Italian corporate ownership. Then we will come back to the question we have just left suspended.

\section{Summary of Part III.}

On a purely legal basis, the following conclusions on the liability of directors of società per azioni can be inferred.

A. Liability to creditors.

A.1. The law does not impose on the board the duty to act in the interests of creditors; however, it imposes a duty not to prejudice their interests by means of illegal acts.

A.2. This duty is sanctioned by allowing creditors to sue directors personally, through an action based on a "tort of interference" in their relationship with the company. When the company is in bankruptcy, creditors lose standing to sue directors in favor of the trustee.

B. Liability to shareholders and third parties.

B.1. General tort law principles would arguably allow shareholders and third parties to sue directors who have injured them. Civil Code art. 2395 (Italy) recalls such principles, but limits standing to persons whom directors injured "directly." Such a limitation prevents individual shareholders from suing directors simply for the loss of value of shares, which is considered an indirect, "second-grade" injury.

B.2. The Italian private law system, unlike most others, admits derivative suits as a general remedy for creditors; yet, Italian corporate law does not provide for derivative suits of shareholders, who, like creditors, have a right whose satisfaction depends on someone else's assets.

B.3. A provisional conclusion is that the system appears to be designed to shield directors from shareholders' suits. But see summary infra C.5.

C. Liability to the company.

C.1. Cases finding directors liable to the company can be classified under three headings: liability for violation of directors' specific duties, liability for negligence, and liability for conflict of interest. Courts tend to be rather strict in cases belonging to the first and third categories, and more or less consciously apply a sort of "business judgment rule" in cases belonging to the second category (negligence claims).

110. C.c. art. 2407 (Italy) refers to art. 2393 and art. 2394 concerning the procedural requirements for suits brought against auditors by the company and its creditors. 
C.2. Apart from an exception (provided for by Civil Code art. 2409 (Italy)), liability suits against directors can be instituted by the company itself, following a majority vote of shareholders, or when the company is in bankruptcy, by the bankruptcy trustee.

C.3. As a starting point to be supported by empirical evidence, we assumed that most actions for liability against directors are instituted by bankruptcy trustees, and that only a minority of such actions is instituted by nonbankrupt companies following a majority vote of shareholders.

C.4. We offered some possible non-corporate governance explanations of such abnormal distribution of plaintiffs in liability actions against directors. However, we advanced the hypothesis that the majority vote requirement may constitute an effective barring, preventing tensions between majority and minority shareholders over directors' mistakes or conflicts of interest from being resolved by a judicial decision.

C.5. Should this hypothesis be proven true, the majority vote requirement for liability suits against directors would assume a different significance: not a protection for directors, but a tool in the hands of the majority shareholders. The legal corporate governance system would reinforce the majority by protecting directors it elects against minority shareholders, and only against them. This conclusion, however, does not necessarily entail a negative valuation if it is not accompanied by the consideration of other factors concerning the balance of power between the majority and minority.

\section{LAW AND SOCIETY: THE ITALIAN INDUSTRIAL SYSTEM AND THE OWNERSHIP STRUCTURE OF ITALIAN COMPANIES}

\section{A. An Industrial System Based on Small Firms.}

In recent years, the Italian gross national product ranked fifth in the world. Italy possesses, in all senses, a developed economy, fully integrated with the other major economies of the world. As is the case with any others, however, the Italian economy has its own peculiarities, the most striking of which is a particularly small average industrial size.

The Italian industrial system is based on small-medium firms. In the early ' 90 s about $99.2 \%$ of Italian firms had less than 100 employees, and $95 \%$ of them had less than twenty employees. ${ }^{11 \prime}$ Looking at the picture from a different point of view, in 1991 about $78 \%$ of the work force was employed by firms with no more than 500 employees, about $59 \%$ by firms with no more than 100 employees, 
and about $32 \%$ by firms with less than ten employees. ${ }^{112}$ All these percentages are significantly higher than those of other large European countries. ${ }^{113}$

Far from declining, this feature is becoming more marked. Thus, at the end of 1991, only 602 Italian manufacturing firms had more than 500 employees, and this number shrunk to 498 at the end of $1994 .^{114}$ More precisely, the trend shows a general decline of large firms and a tendency of small firms to grow both in number and in size. ${ }^{115}$

\section{B. A Follow-up: the Insufficiency of Data on Industrial Size in Assessing the Efficiency of the Italian Industrial System as a Whole.}

The smallness of average Italian industrial size is not the whole story. The number of employees a firm has tells only about the part of the economic activity that takes place inside the firm, under hierarchical coordination. It does not tell anything about the size and the structure of the economic activity that takes place

112. Source: database Istituto Nazionale per la Previdenza Sociale-INPS (public agency on employment benefits), summarized in Alle imprese piace il formato mignon, IL SOLE - 24 ORE, Jan. 4, 1994, at 10 (data of 1991).

113. In Italy, 37\% of firms have between 10 and 499 employees, compared with $27 \%$ in Germany, 20\% in France and 15\% in the United Kingdom (source: EUROSTAT 1992, quoted by MiNisTero DELl'INDUSTRIA \& MEDIOCREDITO CENTRALE, INDAGINE SUlle IMPRESE MANIFATTURIERE. QUINTO RAPPORTO SULL'INDUSTRIA TTALIANA E SULLA POLITICA INDUSTRIALE 66 (1994)). A recent survey of Swedish labor structure showed that in 1993,70\% of the Swedish manufacuring work force was employed by firms with 200 or more workers, and only $12 \%$ by firms with less than 10 workers. Small isn't beautiful in Sweden. THE ECONOMIST, Feb. 18, 1995. at 64 .

114. Telephone interview with Giovanni Scanagatta, General Manager of Research Service of Mediocredito Centrale (Feb. 23, 1995) (citing from CERVED, electronic database of Italian Consortium of Chambers of Commerce. Mr. Scanagatta is the coordinator of the survey cited in the preceding note). Moreover, the national census of 1991 showed that the average for firms with more than 10 employees was 41.9 employees, down from 50.3 in the 1981 census. The same trend is shown by a comparison between data for the years 1984 and 1991 of INPS. See supra note 112).

115. This conclusion is drawn from multiple sources: SERVIzIO STUDI, MEDIOCREDITO CENTRALE, INDAGINE CONGIUNTURALE SUTLE PIOOOLE E MEDIE IMPRESE. SECONDA RILEVAZIONE GENNAIO 1995 ii, iv (draft Jan. 1995) (showing both a process of hiring new workers by smallmedium firms and of creating new firms); Istituto Superiore di Statistica (summarized by Massimo Bongiovanni, Piccole imprese, grandi numeri, IL SOLE - 24 ORE, May 19, 1994, at 18) survey of years $1981-89$ (showing an increase of $15.8 \%$ in firms with less than 20 employees, a decline of $6.2 \%$ in firms with 20 to 49 employees, a decline of $16.9 \%$ in firms with 50 to 99 employees, a decline of $21.2 \%$ in firms with 100 to 499 employees, and a decline of $25.2 \%$ in firms with more than 500 employees). 
outside the firm, in the market, by means of instantaneous exchanges or in longterm, complex contractual arrangement. ${ }^{16}$

All this data tells is that the "efficient boundary"117 of Italian firms are normally small. Possible determining factors and subjects of further research are: the role of labor laws imposing higher burdens on firms with more than a certain number of employees, ${ }^{118}$ the role of "industrial districts" in which small homogeneous firms clustered in the same area achieve economies of various nature, ${ }^{119}$ the existence of stable interfirm relationships mirroring the productive structure of large firms ${ }^{120}$ or at any rate reducing transaction costs, ${ }^{121}$ the existence of quasi-public agencies with the same goals, ${ }^{122}$ and an unsuspected

116. This is, of course, the kind of analysis suggested first by Ronald $\mathrm{H}$. Coase, The Nature of the Firm, 4 EOONOMICA 386 (1937), reprinted in RONALD H. COASE, THE FIRM, THE MARKET AND THE LAW 33 (1988); id., Industrial Organization: A Proposal for Research, in POLICY ISSUES AND RESEARCH OPPORTUNITIES IN INDUSTRIAL. ORGANIZATION 59 (Victor R. Fuchs ed., 1972), reprinted in COASE, supra, at 57, 65, 74 (1988).

117. Ronald J. Gilson, The Political Ecology of Takeovers: Thoughts on Harmonizing the European Corporate Governance Environment, 61 FORDHAM L. REV. 161, 162-63 (1992).

118. The most relevant burdens are triggered when the firm reaches or passes 16 employees (there are a few exceptions, and different ways of calculating the number of employees): art. 18, Law of May 20, 1970, No. 300, as amended by Law of May 11, 1990, No. 108 (duty to rehire non-high level employees dismissed without cause, and higher liability of the employer to them); art. 35 of the same law No. 300/1970 (unions' rights, some of them imposing direct costs on the employer). Additional burdens arise for the employer if the firm passes 35 employees, as the employer must hire a fixed percentage of people having a reduced ability to work.

A clear reaction of such burdens is the phenomenon of micro-groups of companies, often targeted by unions and workers and sanctioned by the courts as "fraud on the law." For a thorough analysis, and a critique, of such doctrine and of cases arising out of it, see Alberto Niccolai, 'Gruppi' di imprese, personalita giuridica e rapporto di lavoro, 1990 NuOVA GIURISPRUDENZA CIVILE COMMENTATA II, 464.

119. For particular focus on the Italian experience of industrial districts, see MERCATOE FORZE LOCALI: IL DISTRETTO INDUSTRIALE (Giacomo Becattini ed., 1987).

120. According to the survey of MINISTERODEL'INDUSTRIA \& MEDIOCREDITO CENTRALE, supra note 113, at 47-48, about a quarter of the 4,811 firms in the sample (representative of the 64,463 Italian manufacturing firms with more than 10 employees in the years 1989-1991) work under subproduction agreements. The percentage is more than $33 \%$ in specialized industries (production of software, industrial machinery, etc.): see table No. 97.

121. MINISTERO DELL' 'LDUSTRIA \& MEDIOCREDTTO CENTRALE, supra note 113 , at 15 (39\% of the firms in the sample had at least one project of interfirm cooperation; see also tables No. 9599).

122. Typical examples of such public or quasi-public agencies ane export interfirm consortia, consortia aiming at lowering the cost of credit by means of a sort of mutual (limited) collateral, companies that insure export trade credits, etc. For a partly critical assessment of the Italian experience with such agencies, as compared to the French, British and German ones, see generally MINISTERO DELL'INDUSTRIA \& MEDIOCREDITO CENTRALE, supra note 113, at $71-77$. 
tendency of Italian small firms to invest in R \& D. ${ }^{123}$ Other factors are less tangible, and their role is even less determinable here. ${ }^{124}$

Advantages and disadvantages of small size have long been described in Italy and abroad, and it is not possible to discuss them in detail. Among the advantages, reduced (or absent) agency costs and high flexibility stand out. ${ }^{125}$ Among the disadvantages are the reduced ability to make strategic investments and a higher sensitivity to financial problems. Although the profitability of Italian small-medium firms is generally in line with that of large firms ${ }^{126}$ and is comparable with the profitability of foreign corporations, we cannot reach a conclusion as to which structure is best, for the Italian economic system or others. If ever such a conclusion is reached, more evidence will be needed.

One thing, however, we can say: the Italian system constitutes a point in favor of the assumption that performance and size are not necessarily interrelated. This does not imply that, with the present technology and with the present legal and social system, every activity can be organized efficiently through small firms. The only conclusion that can be inferred from the Italian experience is that the economic data do not warrant the absolute desirability of a legal system positively encouraging intrafirm growth.

C. The Important Role of the Public Enterprise System.

Another characteristic of the Italian economic system is the strong presence of public enterprise. Wholly or majority State-owned companies have a legal

123. Id. at 21, 24-25. See tables No. 51-65; Daniele Archibugi \& Marco CeccaGnoli, MEdIOCREDTTO CENTRALE, INNOVAZIONE E INTERNAZIONALIZZAZIONE NELLE IMPRESE MANIFATTURIERE ITALIANE 7, 9, 19-29 (1994). Neverthless, surveys show that investments in $R \& D$ are not enough, and that they are higher in Northern Italy than in the rest of the country. Elio Pagnotta, Poca innovazione in azienda, IL Sole - 24 ORE, Aug. 9, 1995, at 13.

124. I could cite a natural individualistic tendency of Italians, but some evidence is needed to introduce elements such as human behavior into an economic analysis. Progress in this direction has been made (Arthur T. Denzau \& Douglass C. North, Shared Mental Models: Ideologies and Institutions, 47 KYKLOS 3 (1994) (emphasizing the importance of cultural heritage as a factor influencing economic choices)); a complete theory, however, seems well in the future.

125. MINISTERO DELL'INDUSTRIA \& MEDIOCREDITO CENTRALE, supra note 113, at 36 and table No. 81 (showing that the highest percentage of firms exporting to Eastern Europe in 198991 were found among firms with less than 21 employees, which reveals a superior ability of small firms in exploiting newly opened markets).

126. There are situations in which performances of small-medium firms and of large firms differ, but such discrepancies seem due to economic trends rather than to permanent factors. For instance, the economic recession of 1992 hurt small firms more, but they were the first to react in 1993-94 (compare Paolo Gnes \& Franco Varetto, Piccole aziende col fiato grosso, IL. SOLE - 24 ORE, Sept. 24, 1993, at 31 (computerized analysis of financial statements of 9,100 Italian firms); with SERvizio Studi, Mediocredito CENTRALE, INDAgINE CongIUNTURALE SUlle PicCole E Medie Imprese. Prima rilevazione setTembre 1994 7, 8, 25, and Servizio Studi, MEDIOCREDITO CENTRALE, supra note 115 , at iii-iv). 
monopoly over production and distribution of electric power supply ${ }^{127}$ and over cable telecommunications. The State directly or indirectly owns and operates an overwhelmingly large portion of the railway system and a large part of other transportation facilities, and owns large chunks of the steel and chemical industries and the financial sector. ${ }^{128}$

The role of the State in the industrial system is, at least in part, the product of forced choices. In the world economic crisis following the end of World War 1, the State intervened in the collapse of the banking system, crippled by participation in industries which had become worthless. Such intervention carried two by-products whose consequences still endure: (a) the State was left with vast holdings in the largest banks and industrial complexes of the country, and (b) "firewalls" were erected between the banking and the industrial system to prevent the crisis from happening again. ${ }^{129}$

That system survived the fall of the Fascist regime in 1943, the establishment of the Republican democratic system in 1946, and the first postwar political elections in April 1948. In the following years, the public enterprise system was used as a tool of intervention, notably, but not only, in some depressed areas of Southern Italy, and as a means of assuaging social conflicts. ${ }^{130}$ Thus, the public enterprise system assumed roles clearly beyond the simple production of goods and services in a free market. ${ }^{131}$ The Italian economic boom during the ' 50 s and ' 60 s sustained both the profitability of a part of the system and the ability of the State to cover, by various means, the losses of the other part.

Both a changing and less favorable economic environment and the enactment and increasingly effective enforcement of art. 92 of the Treaty of Rome ${ }^{132}$ by the European Community authorities produced a crisis in the public enterprise system, one that still lasts. The reduced economic and legal ability of

127. Law of Dec. 6, 1962, No. 1643. Only recently has self-production for enterprises and groups of companies been allowed (art. 9, Law of Oct. 10, 1990, No. 287).

128. Financial institutions (mainly banks and insurance companies) were relatively easy to privatize, and, with the exception of Banca Nazionale del Lavoro (BNL), were privatized berween the end of 1993 and the summer of 1994. See infra note 134.

129. For the analysis of the legal structure and consequences of the separation between banking and industrial system before the reform of 1992-1993 (on which see infra note 183 and accompanying text), see RENZO COSTI, L'ORDINAMENTO BANCARIO 330 (1st ed. 1986).

130. See supra note 57 for some examples of the problems created by the range and variety of activity committed to the public enterprise sector.

131. In Italy the State has assumed the conflicting roles of both "referee and player," according to a colorful metaphor of ROMANO PRODI, IL TEMPO DELLE SCEI.TE. LFZIONI DI ECONOMIA 84 (1992).

132. Art. 92, Par. 1, Treaty of Rome: "Save as otherwise provided in this Treaty, any aid granted by a Member State or through State resources in any form whatsoever which distorts or threatens to distort competition by favouring certain undertakings or the production of certain goods shall, insofar as it affects trade between Member States, be incompatible with the common market." Par. 2 of art. 92 sets forth some exceptions for aid having social purpose or development goals. 
the State to inject money into the public sector resulted in systematic undercapitalization and, in some cases, in outright failures. ${ }^{133}$

The system, now for the first time under pressure by all political parties, will almost certainly undergo a drastic change in the next few years. Any forecast about its future size and role is thus impossible at the moment. It is enough to observe that, after more than sixty years, the effects of the post-World War I choices are still there. As we will soon see, the "firewalls" erected between banks and industry were dismantled only two years ago, when the industrial system was irreversibly shaped, and the long needed process of privatizing public enterprises is still taking its first steps. ${ }^{134}$

\section{The Ownership Structure of Unlisted Companies.}

Very large Italian businesses are run by companies that never went through a public offering. Public capital markets play a rather marginal role in Italy: a large part of the productive system is made up of companies not listed on any stock exchange or interdealer system, and whose capital is not otherwise widely traded. ${ }^{135}$ This is hardly surprising given the small average industrial size, but

133. Ente Finanziamento Industria Manifatturiera, or EFIM, one of the four largest public holdings, was liquidated by an emergency law. Government Decree-Law of July 18, 1992, No. 340, converted, after several reenactments, by Law of Feb. 17, 1993, No. 33. The crisis has not yet been completely solved after almost three years. Most of EFIM's assets, consisting of large mechanical and defense firms, have been transferred to the first public holding (IRI), and the debts, amounting to several trillion liras (1.7 trillion liras equals approximately one billion U.S. dollars), have been paid by the State, which was authorized to do so by the European Union.

134. The process of privatization of State-owned enterprises, heralded by several laws, accelerated dramatically in 1992 under the Amato Government. The collapse of EFIM (see supra note 133), a deep and still lasting public deficit, and a changed general consciousness of publicprivate relationship induced the Government, supported by the Parliament, to start a privatization program involving most state enterprises (art. 15, 16, Law of Aug. 8, 1992, No. 359). As of August 1995, only three banks (Credito Italiano, Banca Commerciale Italiana and Istituto Mobiliare Italiano), an insurance company (Istituto Nazionale delle Assicurazioni) and a few industrial companies (among them Nuovo Pignone, acquired by General Electric) have been privatized, principally through public offerings (for some of them the State has retained a minority share), but other important companies seem on the way (notably, the oil and natural gas holding, ENI, the telephone holding, Stet, and the electrical power company, ENEL).

135. Examples are extremely rare of companies that, although unlisted, are widely held and traded. (One of the few widely held unlisted companies, Banco S. Geminiano e S. Prospero s.p.a., a large local bank with a very unusual control group, was the target of a finally successful hostile takeover in October 1993.) The total volume of Italian over-the-counter trading amounts to a total of about one trillion liras [about $\$ 600$ million] a year (Enzo Berlanda, Chairman CONSOB, quoted in Giuliano Boggiali, Consob dice si al Nasdaq, IL SOLE - 24 ORE, May 28, 1994, at 21), and it is therefore negligible from our perspective. We can then fairly say that only three ownership patterns of societd per azioni exist in practice:

(a) the closely held societd per azioni, where "closely held" means held by very few shareholders, usually less than 10 and strictly related among themselves; again, I stress that in 
several other factors, which will be examined in Paragraph IV.I., concurred.

Unlisted companies are usually controlled by an individual shareholder or by a close group of shareholders (often members of a family). Typically each shareholder owns a significant share of the capital, and a web of shareholders' agreements on corporate governance and of restrictions on transfers of shares keeps ownership firmly in the hands of the founding group. ${ }^{136}$ Of course, no

Italy, a closely held company does not necessarily mean a small business;

(b) the joint-venture, or consortium, with the form of societd per azioni, whose shareholders are entrepreneurs incorporating the company to accomplish a specific task; the capital of this kind of company is not traded, the receipt of dividends not being the primary goal of shareholders. In many respects this is not a real, for-profit societa per azioni and presents peculiar problems;

(c) the widely held, listed, societd per azioni, with a clear subdivision between controlling shareholders and passive investors (even if the relative quantities may vary: see infra paragraphs IV.E. to IV.H.). (A similar, but not identical, three-fold division was made by 2 ASCARELLI, supra note 57, at 1003-07.)

136. Restrictions on transfer of shares are set forth in clauses of the charter or, less frequently in unlisted companies, they are a part of a broader shareholders' agreement. (Transfer restrictions on shares of listed companies can only be set forth in shareholders' agreements, free transferability of shares according to the charter being a precondition for a listing on the Italian Stock Exchange: see infra paragraph IV.G. The issue is, however, more complex than this, as there are some exceptions, and ownership caps have been deemed compatible with listing.) Restrictions on transfer of shares present several forms, and they are often extremely complex. On the basis of their structure, it is possible to single out five basic kinds of clauses limiting the free transfer of shares:

(a) Clauses requiring the transfer be approved before it can take effect for the company. The distinctive feature of this first kind of restriction is that the transfer may not take effect for the company unless discretionary approval is given. Approval is usually the prerogative of the board of directors or of the majority of the shareholders (including the shareholder who sells: it is not as such an antitakeover device similar in effect to the "control share acquisition statute" analyzed by Ronald J. Gilson \& Bernard S. Black, The law and Finance of Corporate ACQUISITIONS 601-02 (Supp. 1993), for it has an antitakeover effect only in the rare cases in which the controlling group has less than the absolute majority). The Court of Cassation, reversing a well-established trend, ruled in 1978 that consent or denial cannot be absolutely discretionary (Judgment of May 15, 1978, No. 2365, Cass. civ., 1978 GIURISPRUDENZA COMMERCIALE II, 639), and the standard established by the Court of Cassation seems to have been written into law by art. 22, Law of June 4, 1985, No. 281. The amount of discretion deemed acceptable, however, is still far from clear.

(b) Clauses giving a "power of first refusal" to shareholders. This clause gives to a group of insiders, typically the remaining shareholders, the right to acquire pro-rata the shares of the selling shareholder, with preference over the prospective buyer chosen by the selling shareholder. The purchase price is usually equal to the amount agreed upon by the selling shareholder and the buyer; sometimes the price is directly or indirectly determined by the charter, in which case, in my opinion, the clause becomes closer to a repurchase clause (see infra). The right of first refusal clause is extremely common and heavily litigated for the following main reasons: (1) it is (questionably) immune from judicial criticism, unlike the clause requiring that the transfer be approved (whose role it has partly taken over in limiting the free transfer of shares), and (2) by its very structure and not in consequence of the dispersion of shareholders, it is the only clause that gives the minority the power to react when controlling shares are sold. 


\section{market for shares of such companies exists.}

Small-medium companies are usually the product of the effort of an individual, or of a joint effort of closely related people. Their ownership structure tends to be absolutely homogeneous. Shareholders are directly interested in the $\mathrm{firm}^{\mathbf{1 3 7}}$ and sometimes are shareholders of a company exercising a related activity.

(c) Clauses requiring that shareholders have personal qualities. Such clauses give effect to transfers only if the purchaser possesses specific qualities, e.g., possesses a certain professional diploma or is engaged in a particular industry. They are common in professional companies (e.g., engineering companies) and in consortium-like companies (i.e., joint-ventures among a wide group of firms achieving economies or setting up a common service). These clauses may also appear elsewhere as an integrative, rarely exclusive device meant to control ownership. They are generally considered unproblematic.

(d) Clauses imposing a ceiling on shareholders' ownership. Largely unstudied, this kind of clause has recently been inserted in the charter of newly privatized companies, thus assuming a high political value. (No single shareholder, or group of shareholders associated, is supposed to acquire complete control of such companies; it is at least doubtful that the device of the ownership cap, as in fact it has been geared, can achieve such a goal). The effect of such clauses is to maintain the relative ownerships in an equilibrium envisioned by the first shareholders in the charter. (Problems arise for midstream amendments). The structure remains the same, but the substance changes according to the percentage of ownership allowed: a ceiling fixed at three to ten per cent can be found in joint-ventures among many firms or in real for-profit companies with a composite controlling group (not necessarily a public company, as the first Italian experience of privatization demonstrates); a ceiling fixed at over ten percent (very often at fifty per cent) can be found only in closely held corporations or in bilateral joint ventures in which the participating groups want to protect themselves against reversals of alliances. (For a clear example of such a factual pattern, see Judgment of Feb. 8, 1992, Tribunal of Milan, 1992 GIURISPRUDENZA ITALIANA I-2, 489, involving the descendants of the two founders of the company.)

(e) Repurchase clauses. Repurchase clauses give to some shareholders the right to acquire the shares of one or more shareholders when a certain event, provided for by the charter, occurs (typically, the discontinuation of an agreement for personal services or the death of a shareholder). The purposes of repurchase clauses can be various: to solve deadlock problems, to give incentives to the shareholders to offer valuable services (for a case involving shareholders of an insurance brokerage service corporation, see Judgment of July 14, 1982, Appellate Court of Milan, 1983 GUURISPRUDENZA COMMERCIALE II, 397) or, more often, to simply control ownership (for a clear example, see art. 6 of the charter of "Giovanni Agnelli \& C. s.a.p.a.," supra note 10).

For statistics on restrictions on transfer of shares see, recently, Goffredo Zuddas et al., Ancora sui limiti al trasferimento delle azioni nella pratica statutaria, 1988 GIURISPRUDENZA COMMERCLALE I, 897; Giorgio M. Zamperetti, Le clausole di gradimento nella recente prassi statutaria, 1988 GIURISPRUDENZA COMMERCIALE I, 915 . Both works, based on slightly different samples, show a very high frequency of restrictions (about $63 \%$ of companies recently incorporated had at least one kind of restriction, according to Zuddas et al., supra, at 901), and, in particular, right of first refusal clauses (more than $80 \%$ in the sample examined by Zamperetti, supra, at 916 , concerning the Milan region).

137. This does not exclude the fact that shareholders are sometimes passive components of the controlling family. We can assume homogeneity of interests between active shareholders and members of their family, at least until a conflict arises. 
Institutional investors are rarely found, and until now, ${ }^{138}$ have been limited to merchant banks ${ }^{139}$ and venture capitalists. ${ }^{10}$ Shareholders (or managers of companies that are shareholders) and directors usually coincide, and typically the company hires full-time professional managers, who work closely under the supervision of directors. ${ }^{141}$

Given the homogeneity of shareholders, generally unlisted companies do not have institutional majorities and minorities. Of course, conflicts among shareholders do arise here also. However, the conflicts arise in most cases because, for some reason, the harmony that once reigned among shareholders has broken down, and not because there is real dissent over the management of the company. In other words, dissent over the management of unlisted companies is more likely to be the product of conflicts among shareholders than to be their cause. ${ }^{142}$

138. Changes, even very important ones, might take place in the near future following the beginning of operations of closed-end investment funds, pursuant to the recent enactment of their discipline (Law of Aug. 14, 1993, No. 344) and the lifting of separation between banks and commercial firms (see infra note 182 and accompanying text).

139. The Italian merchant banking market is growing (37\% of the newly listed Italian companies in the years 1987.91 came from operations of merchant banking) but is still not fully developed due to the absence of a strong secondary market and to an unfavorable tax regime. See Symposium, Capitale di rischio in cerca di mercato, IL SOLE - 24 ORE, May 11, 1993, at 28; Gianfranco Imperatori, Merchant, si al Nasdaq all' italiana, IL SoLE - 24 ORE, Apr. 19, 1994, at 31.

140. As of 1993, Italy, with 3,802 billion ECU of total funds raised, had the fourth-ranking venture capital market in Europe, following the United Kingdom (17,038 billion ECU), France ( 8,570 billion ECU), and Germany $(4,267$ billion ECU), and preceding Holland (1,702 billion ECU), Spain (1,232 billion ECU) and Sweden (1,010 billion ECU). Still, the importance of the market is relatively limited in amount.

The peculiarities of the Italian venture capital market, as of 1993, were the following: (a) more than $71 \%$ of the funds came from banks, through subsidiaries, compared to about one-third of the European average; (b) few resources were directed toward start-up companies (11.4\% of operations and $1.1 \%$ of amount invested), while most of them financed expansion projects (47.7\% of operations and $63.7 \%$ of amount invested); and (c) the Italian market has a higher presence of foreign capital (20\%) than the average (EUROPEAN VENTURE CAPITAL ASSOCIATION, 1993 REPORT, discussed in IL SOLE - 24 ORE, June 20, 1994, at 36).

141. This point will be stressed infra note 189 and accompanying text.

142. This is not to say that challenges to the management in this setting are usually without merit. The factual pattems underlying most judicial decisions show that very often conflicts among shareholders have turned directors from fiduciaries of all the shareholders into fiduciaries of the majority alone-or at least this is the claim of the minority. When this in fact has happened, and it is the task of the court to ascertain if it has, challenges do have merit. No general conclusion as to the merit of challenges to directors in a highly concentrated ownership structure context can be drawn, nor does it have to be. All we can say is that in such a setting, the legal system of directors' liability, rather than being a physiological monitoring tool over directors, determines the balance of power between majority and minority shareholders, thus influencing the outcome of conflicts between them. 


\section{E. The Ownership Structure of Listed Companies.}

Italy has a rather small public stock market. In June 1995, only about 240 Italian companies were listed and regularly traded on the Italian automated stock exchange ${ }^{143}$ and on the minor stock exchange. ${ }^{144}$ In 1993, the total capitalization of the Italian Stock Exchange was about fifteen percent of the GNP, a percentage substantially lower than in other industrialized nations. ${ }^{145}$

Although a handful of Italian companies listed on foreign exchanges must be added to these numbers, ${ }^{146}$ it is clear that few Italian companies, out of many more eligible, ${ }^{147}$ resort to the public market for their financing needs. True, the number of Italian listed companies, and thus the Italian stock market as a whole, is growing. ${ }^{148}$ Nevertheless, for some years to come, the public stock market will

143. The "Borsa Valori" of Milan, which was the main Italian stock exchange, technically does not exist anymore. It was completely taken over in 1994 by an automated exchange system, whose administrative and operating headquarters are still in Milan. The reform has been implemented by CONSOB regulations, empowered to carry on a general reform of the Italian public financial market by art. 20, Law of Jan. 2, 1991, No. 1.

144. The "Mercato ristretto" [Restricted stock exchange], has a limited importance and small daily volumes (an average of less than 10 million dollars in 1995). Minor stock exchanges can be established by joint public-private corporations, under CONSOB regulation of Sept. 30 , 1994 , No. 8469, supra note 22. Several projects have been started, but as of March 1995, none has begun operations.

145. In the same year, the percentage of capitalization was $21.2 \%$ in Germany, $37.6 \%$ in France, $61 \%$ in Holland, $66 \%$ in the United States, $68.2 \%$ in Japan, and $129 \%$ in the United Kingdom (Federico Rendina, Borsa vietata ai piccoli e dominata da pochi 'big,' IL SOLE - 24 ORE, Dec. 17, 1994, at 31). In early 1994, the total capitalization of the Italian Stock Exchange amounted to 290,607 trillion liras (Ettore Livini, Piazza Affari, diluvio d'aumenti, IL SOLE - 24 ORE, Oct. 27, 1994, at 31).

146. This is the case, for example, of Luxottica Group s.p.a. and Natuzzi s.p.a., listed on the New York Stock Exchange and not listed on the Italian Stock Exchange (for a survey of these two companies see Italy's Luxottica and Natuzzi are showing that remote locations need not hinder growth, Financial Times, Mar. 10, 1995, at 15). Companies listed both in Italy and abroad (e.g., Fiat s.p.a.) are obviously not included in the count.

147. Experts estimate the number of Italian companies eligible for a public offering and following listing on the primary stock exchange to be between 1,000 (Attilio Ventura, Chairman of the Exchange Council, IL SolE - 24 ORE, Mar. 26, 1994, at 29), 1,500 (Enzo Berlanda, chairman of the CONSOB, IL SOLE - 24 ORE, Apr. 9, 1994, at 25), and 1,700 (Antonio Fazio, Governor of the Bank of Italy, LA STAMPA, June 23, 1994, at 19). Extremely significant is the fact that the average capitalization of companies listed on the Italian Stock Exchange is roughly twice that of the companies listed on the NYSE (Source: CONSOB, quoted in Rendina, supra nóte 145).

148. The number of companies listed in Italy (primary stock exchange) grew from 147 in 1985 to 206 in 1993, while at the same time the number of companies listed on primary stock exchanges shrunk (slightly) from 489 to 472 in France, from 472 to 426 in Germany and from 2,188 to 1,927 in the United Kingdom (source: RAPPORTO IRS SUL MERCATO AZIONARIO 1993 (1994), discussed in Alberto Ronchetti, Matricole cercansi, MONDO ECONOMICO, Jan. 30, 1995, 
probably remain a comparatively less important institution in Italy than it is abroad.

Even more important, however, is the ownership structure of these companies. Data regularly collected by the CONSOB, the supervisory agency for public capital markets, and regularly published pursuant to the Italian law on tender offers, ${ }^{149}$ reveal that all but around fifty listed companies have a shareholder or a group of shareholders stably associated holding more than fifty percent of the voting capital. ${ }^{150}$ Estimates keeping account also of "informal" associations among shareholders (family relationships, principally) put the number of companies without an absolute majority controlling group at around thirty. ${ }^{151}$ All other companies, i.e., more than 200 , are not only closely watched by powerful shareholders but also takeover-proof. ${ }^{152}$

There is more. Even in companies with a float higher than fifty percent, shareholders have a strong voice; the same data shows that most of these companies have shareholders, or stable associations of shareholders, holding between fifteen and forty-nine percent. ${ }^{153}$ Very few companies, also having large shareholders, are possible targets of hostile takeovers, and, interestingly enough, one of them was taken over in early 1995.

There are a few real public companies in Italy: the banche popolari [popular banks], many of which are listed and very healthy. They are public companies, however, not because of the spontaneous play of market forces, ${ }^{154}$ but

at 65). (The number of companies listed on the Italian Automated stock exchange was 222 in June 1995: Fib 30 promosso nel semestre, IL SOLE - 24 ORE, Aug. 9, 1995, at 23.) A decisive thrust to the increase in the number of listed companies has come from a very favorable, if temporary, tax regime introduced in 1994 for companies that choose to go public.

149. Art 10(3), Law of Feb. 18, 1992, No. 149. Data are collected from notifications by shareholders having more than two per cent, mandated by art. 5 to 5-sexies, Law of June 7, 1974, No. 216. The frst list of companies and percentages was embodied in Comunicazione CONSOB No. 92005380, published in GAZZETTA UfFiciale, Aug. 3, 1992, No. 181, and is regularly updated.

150. "Voting capital" means capital giving the right to vote in ordinary meetings where directors are elected (supra note 37).

151. Walter Riolfi, AAA public company cercasi, IL SOLE - 24 ORE, July 19, 1994, at 29.

152. This is probably a slight overstatement because of the uncertain validity of sharcholders' agreements. See infra paragraph IV.G. A scenario in which the agreement breaks down under pressure from a hostile bidder, and some of its members tender their shares is therefore theoretically possible. This did not happen, however, in a hostile takeover attempt of Banco Ambroveneto s.p.a. that took place in fll 1994. For more details, see infra note 175 and accompanying text.

153. See infra paragraph IV.H. for detailed data on ownership structure.

154. For "spontaneous play," I mean the play of market forces once the regulatory framewark is given, as pointed out by ROE, supra note 16. 
because of their peculiar legal structure, based on a very low ownership cap for each shareholder $(0.5 \%)$ and on the one-shareholder-one-vote principle. ${ }^{155}$

Apart from this exception, for a number of reasons negligible from our perspective, ${ }^{156}$ the governance structure of Italian companies rests on the influence of "strong owners" over not weak, but simply faithful managers. ${ }^{157}$ Let

155. Art. 30, Legislative Decree of Sept. 1, 1993, No. 385, has reformulated, and slightly amended, if not in this respect, a long-standing principle. Apart from some classical phenomenon of separation between ownership and control (fragmentation, absenteeism, self-perpetuating board, contexts for control in form other than a tender offer, etc.), which can easily fit into the traditional literature on the topic, the govemance of the banche popolari is largely an unstudied subject.

156. Banche popolari have a fair, if far from dominant, share of the Italian retail banking market, and as noted in the text, they are performing well. The trend, however, appears to be lowards their "demutualization," favored by the new banking law (art. 31, Legislative Decree of Sept. 1, 1993, No. 385). Moreover, it is clear that not every enterprise can be organized on the one-shareholder-one-vote principle and on such a low ownership cap. The success of such a scheme, indeed, is closely tied to the structure of the firm's activity and to the economic and social environment in which it operates. HENRY HANSMANN, THE OWNERSHIP OF THE ENTERPRISE (forthcoming, 1995) (success of mutual companies is higher in banking and insurance industries, due to asymmetric information between banks and insurance companies, on the one hand, and depositors and insureds, on the other hand. This success tends to decrease as the economy develops).

157. I am obviously borrowing the terminology, reversing it, from RoE, supra note 16. The phenomenon of shareholders' influence is so resistant that it has survived recent attempts to counter it by force of law. After intense political debate, and pursuant to a temporary Government Decree-Law enacted five times from September 1993 to May 1994 and finally converted by the Law of July 30, 1994, No. 474, an ownership cap varying from three to ten percent was introduced into the charter of newly privatized companies. At the first shareholders' meetings of the two banks with an ownership cap set at three percent, the directors were elected by a number of shareholders with significant holdings (from about 0.5 to almost $3 \%$, totalling together between 15 and $20 \%$ ), with a ratio between large shareholders and directors close to one-to-one. See, e.g., as for Credito Italiano s.p.a., LA STAMPA, Apr. 18, 1994, at 12, and for Banca Commerciale Italiana s.p.a., IL SOLE - 24 ORE, Apr. 24, 1994).

For deep insights into the debate surrounding Italian privatizations see, in English, On sale in Italy, THE ECONOMIST, Oct. 16, 1993, at 15, and the response of the then Italian Minister for Industry, Paolo Savona, THE ECONOMIST, Dec. 18, 1993, at 6 . In the former, the benefits of a popular-capitalism approach to Italian privatizations, and in the latter, the risks of a blind sale to not necessarily interested shareholders are outlined. As often happens when dealing with Italy, THE ECONOMIST, however well informed, had a quite factious and snobbish tone, and the polite remarks of $\mathrm{Mr}$. Savona were fully justified regardless of which approach one favors.

For documents in Italian, see, on the so-called public company-approach (with ownership cap) side, Romano Prodi and the majority of the Ciampi government, under which the first flotations were implemented. See detailed accounts on this position in Umberto Mosetti \& Vincenzo Visco, I nemici della public company, IL SOLE - 24 ORE, Oct. 14, 1993, at 6 (outlining the peculiarities of the Italian financial market); Giangiacomo Nardozzi, La Borsa aspira ad un ruolo nelle nuove public company, IL SOLE - 24 ORE, Feb. 13, 1994, at 19. (The Berlusconi Government followed the same road, but slightly changed the rule on the ownership cap, as a response to the partial failure of the experiment. See art. 3(3), Law of July 30, 1994, No. 474.) 
us look at the causes of this phenomenon.

\section{F. Expanding the View: the Structure of the Control Group in Listed Companies.}

The control group in Italian listed companies currently presents only two possible forms: (a) a shareholder having alone a controlling share; (b) a group of shareholders acting together and controlling the company. No managercontrolled firm has emerged so far.

A. Control by a single shareholder. Even in large companies, a single shareholder often holds a controlling share. This concentration, however apparently impossible in large companies, has a simple explanation. Typically, such a shareholder is not an individual, but a holding company, which in turn is controlled by one or more large shareholders. Thus, the problem of the structure of the control group is not solved, but arises again at the next level (and possibly. further), which we will examine immediately below.

The device of "pyramided" holding companies as a means to retain control, well known since the time Berle and Means wrote, ${ }^{158}$ has been widely used in Italy. Its effects have been amplified in the past by the possibility of listing on an exchange more than one of the members of the chain. ${ }^{159}$ This possibility now remains only for holding companies performing a real economic activity, and has been suppressed for mere "Chinese boxes." ${ }^{160}$ For our purposes, we simply "look

On the opposite side, favoring a guided sale, or at least disfavoring any ownership cap, see Attilio Ventura, IL SOLE - 24 ORE, Dec. 9, 1993, at 29; Bruno Visentini, La sconfitta di Prodi, LA REPUBBLCA, Apr. 28, 1994, at 1 (vibrant critique of the experience of the first privatizations); Pier Giusto Jaeger, quoted in Giuliano Boggiali \& Raffaella Zagordi, La public? Solo uno slogan, It SOLE - 24 ORE, May 11, 1994, at 28 (diffused ownership cannot be created simply by force of law).

158. BERLE \& MEANS, supra note 15 , at 72-75.

159. A clear example of this phenomenon is the strucure of the so-called "Orlando group," the largest European group for semi-finished copper products, as of January 1995 (a merger and some changes took place a few months later). Eleven shareholders form part of an agreement that controls the $63.1 \%$ of Gim s.p.a., listed on the Italian Stock Exchange, which controls the $47.6 \%$ of Smi s.p.a., listed on the Italian Stock Exchange as well, which in turn controls the $44.5 \%$ of Europa Metalli s.p.a., third company of the chain listed on the Italian Stock Exchange. (To go on with the game, Europa Metalli s.p.a. controls Kabelmetal Ag, listed on the Frankfurt Stock Exchange, and the group has subsidiaries all over Europe.) Both Smi s.p.a. and Europa Metalli s.p.a. have some large, very influential, "extemal" shareholders (graphics in IL SOLE - 24 ORE, Jan. 19,1995 , at 27).

160. Art. 6(2), Regulation CONSOB of May 24, 1989 No. 4088. The CONSOB reserves the right to deny approval of listing to companies "whose economic performance depends essentially on the economic performance of only one block of shares issued by a listed company," even if they possess all other requirements for listing. The Official Report of CONSOB on Regulation No. 4088/1989 stresses that such a company "lacks functional autonomy," and while a "holding company performs an activity of risk diversification and transformation, the "Chinese 
through" the holding company to discover the real controlling group. Behind it there might be a single shareholder, but very often there is a group, which takes us to the second class of hypotheses.

B. Control by a group of shareholders acting together. In almost every company the control is shared among a group of large shareholders. Such groups, however, assume in practice three different forms.

The first form is the family group, in which families exercise control. Normally family control is a remnant of the firm's founding process: it may resist time, remaining in perfect shape, but once it is lost it rarely comes back. ${ }^{161}$ The nature of the relationship among shareholders may be sufficient to keep them aligned as a group; shareholders of a family may then waive the necessity to put the agreement in writing. When this happens-and it inevitably does when the family widens and ties loosen-the case falls in the second category.

The second form is control through a shareholders' agreement. This is probably the most common form for two reasons: not only do shareholders with a significant share of the capital normally agree on corporate governance, but in addition, shareholders having alone a potentially controlling share tend to stipulate agreements with other large shareholders. ${ }^{162}$ Agreements vary in object and structure; their validity, and hence their enforceability, is highly doubtful. Due to their importance, we will further deal with shareholders' agreements below.

The third form of control is new, and rather mysterious. In a few newly privatized companies, apparently without any previous consultation, the largest shareholders have agreed to elect themselves to the board reciprocally (more precisely, to elect their representatives), thus giving rise to a strange kind of

box,' set up by the majority shancholder to raise risk capital without imperiling his control, is only a means to minimizing contributed capital and risk."

A typical example of listed "Chinese box" is Bonifiche Siele s.p.a., whose sole relevant asset is an almost absolute majority holding in Banca Narionale dell Agricoltura s.p.a., also listed. This created serious problems in early 1995, in connection with the transfer of control of Bonifiche Siele s.p.a. because of the uncertainty about the obligation of the buyer to launch a follow-up tender offer on the stock of Banca Nazionale dell'Agricoltura s.p.a. This is required, in connection with transfer of control of unlisted parents of listed subsidiaries, by a (very reasonable) CONSOB interpretation of the Law of Feb. 18, 1992, No. 149, on tender offers.

161. An example of a successful family empire that escaped from the family's hands is the Ferruzzi group, which fell into a deep financial crisis in 1993 and was taken over by the creditorbanks. At the time of the change of ownership it was the second Italian private group after the Fiat group.

162. For example, this is the case of the shareholders' agreement involving Fiat s.p.a. The largest shareholder, sub-holding for the controlling family (which as a whole, directly or indirectly, holds a share around one-third of the capital of Fiat), has stipulated an agreement with four shareholders with shares ranging from two to around three percent. See IL SOLE - 24 ORE, May 14, 1994, at 31. 
spontaneous-concerted action. ${ }^{163}$ Many voices claimed the existence of undisclosed agreements between shareholders, but a CONSOB probe found no evidence of agreements whatsoever. It is instead very likely that each large shareholder, in a perfectly rational and independent way, decided to converge with the others in governing the company under a non-adversarial, cooperative model. Social studies might show how much the usual patterns of corporate governance-the "shared mental models" of the Italian business community ${ }^{164}$ - have been at work.

The most interesting and problematic governance institution is shareholders' agreements. Let us look at them in further detail.

\section{G. Shareholders' Agreements as Non-legal, or At Least Only Partly Legal, Institutions of Governance of Italian Companies.}

Shareholders' agreements on corporate governance are one of the most controversial topics in Italian corporate law. Authors have different opinions as to their validity, while courts tend to look at them with suspicion.

Shareholders' agreements may involve the right to vote, the right to transfer shares, or both. Shareholders' agreements involving the right to transfer shares (so-called "sindacati di blocco," or block syndicates) are not considered very problematic from the standpoint of validity, ${ }^{165}$ and instead create serious problems of enforcement. ${ }^{166}$ By virtue of these agreements, the parties usually agree not to dispose of their shares for a certain period of time, or grant each other a right of first refusal.

163. See supra note 157, for the case of Credito Italiano s.p.a. and Banca Commerciale Italiana s.p.a.

164. Denzau \& North, supra note 124.

165. But see Guido Rossi, Le diverse prospettive dei sindacati azionari nelle societd quotate $e$ in quelle non quotate, 1991 RIVISTA DELLE SOCIETÀ 1353, 1364-65, arguing against a different treatment of agreements involving the right to transfer the shares as opposed to agreements involving the right to vote (which will be examined subsequently in the text). It is true that the two sets of provisions are often intermingled, and tend to the same result; nevertheless, courts focus on provisions of the second kind, possibly to strike down the entire agreement (as happened in the Mondadori s.p.a. case, for which see infra note 167). The same distinction is made in France, where while courts seem favorable to the validity of "accords [qui] visent la transmission des titres," the validity of "[accords] sur la repartition des postes d'administrateur" is more uncertain. Yves Guyon, Les Investisseurs Institutionelles en Droit Français, in INSTTUUTIONAL INVESTORS AND CORPORATE GOVERNANCE, supra note 1, at 385, 395.

166. See generally Alessandro Pedersoli, Sindacati di blocco: validitd, tipi ed effetti, in SINDACATI DI vơTOE SRDACATI DI BLocco 231 (Pier Giusto Jaeger \& Franco Bonelli eds., 1993) (examining problems of judicial enforcement); Franco Bonelli, Clausole di prelazione: modelli per evitame l'aggiramento, in SINDACATI DI voTO E SINDACATI DI BLOCCO, supra, at 255 (examining problems of drafting effective block agreements). 
The structure of shareholders' agreements involving the right to vote (so called "sindacati di voto," or vote syndicates) is usually much more complex. Such agreements present many shades of binding force for the contracting shareholders, ranging from mere commitments to meet before any scheduled meeting of the board or of shareholders, to commitments to vote as all the parties or a majority of them agree, to transfers of the syndicated shares to a fiduciary that will vote as the majority indicates, and to flat arrangements on how the board must be composed.

Courts consider shareholders' agreements which restrict the right to vote to be void. This means that most of the arrangements above described-indeed, the most effective arrangements from a corporate govemance standpoint-are unenforceable. The argument in support of this conclusion rests on the illegality of every attempt to tamper with the free interplay of the company's organs, as structured by legislators. In other words, according to the courts, the default system of corporate governance can be modified-within precise limits-by the charter, but it cannot be deprived of significance by devices external to the corporate structure. ${ }^{167}$

Even if the most recent court decisions have smoothed its corners a little, this doctrine appears to be more emotionally based than sound. ${ }^{168}$ Other theories against the validity of shareholders' agreements rest on different principles, which can be disposed of much less easily. The most convincing of them claims that shareholders' agreements in listed companies infringe the "equality of treatment" principle, which is mandated by market rules and by the legal system as a whole. ${ }^{169}$ On the opposite side, other theories favor shareholders' agreements because of their legality and the opportunity, as devices to achieve

167. For a careful step-by-step account of the (few) cases, see Mauro Bernardini, Rivisitando la giurisprudenza sui sindacati di voto, 1988 CONTRATTO E IMPRESA 716; the following affair, involving two large groups (Fininvest, controlled by Silvio Berlusconi, then still far from the political arena, and CIR, controlled by Carlo De Benedetti) fighting over the control of the Amoldo Mondadori Editore s.p.a., started with cross-requests for injunctions in December 1989 and ended in an arbitration ruling affirming the validity of a complex shareholders' agreement, which was subsequently voided by Judgment of Jan. 14, 1991, Appellate court of Rome, 1991 GIURISPRUDENZA COMMERCIALE II, 448. (The dispute was eventually settled.)

168. For an excellent review and critique of the dominant courts' position, see FERRARA \& CORSI, supra note 2, at 447-53.

169. Rossi, supra note 165 , at 1367-74. The "equality of treatment" principle is now mandated, for listed companies, by art. 4-ter, Law of June 7, 1974, No. 216, introduced by Legislative Decree of Jan. 27, 1992, No. 89. This provision, however, does not automatically invalidate shareholders' agreements, as it refers only to how the company must treat its shareholders. (This provision may prevent some of the most aggressive takeover defense measures, which are known in America, such as poison pills; the great majority of them, however, would nevertheless incur in the general prohibition set forth by art. 16, Law of Feb. 18, 1992, No. 149 , on tender offers, discussed briefly infra note 237 .) 
stability of management, to pursue long-term policies, and to make "business" prevail over "finance." 170

It is evident that the matter is far from settled. ${ }^{171}$ Both sides present very serious arguments; thus, formal reasoning aside, the question of the validity of shareholders' agreements is largely one of policy. Disfavoring secret governance arrangements cannot be used as a general argument against the validity of shareholders' agreements because, at least for listed companies, the CONSOB must be notified of the existence of arrangements involving the transfer of shares or the right to vote, and the content of these arrangements must be published. ${ }^{172}$

The phenomenon of shareholders' agreements, however, has a life of its own, far from the rumors and the publicity of courtrooms. ${ }^{173}$ Shareholders' agreements are incredibly widespread, in small as well as in large companies. Moreover, in listed companies they appear to be the rule rather than the exception. Given the courts' criticism, of which everyone is obviously well aware, shareholders' agreements must rest on other institutions: honor, reputation, or fear of informal but nevertheless effective sanctions. ${ }^{174}$

It is beyond question that shareholders' agreements perform a primary role in the governance of Italian companies, especially listed companies. What remains to be seen is what kind of stability they give to the control group, i.e., how they react under the pressure coming from a bidder. If they do not break up and tend to resist, then they can be considered an almost perfect substitute for a single shareholding when considering the stability of governance structure.

170. Berardino Libonati, Sindacato di voto e gestione d'impresa, 1991 RIVISTA DEL DiRTTOCOMMERCIALE I, 97, 103. Among those who deem shareholders' agreements generally valid, see also Pier Giusto Jaeger, Il problema delle convenzioni di voto, 1989 GIURISPRUDENZA COMMERCIALE I, 201; Renzo Costi, Il problema della validitd dei sindacati di voto nella legislazione più recente, in SINDACATI DI VOTOE SINDACATI DI BLOCCO, supra note 166, at 25.

171. It is quite interesting to note that on both sides there are many authors with an extensive comparative knowledge (mostly French, German and American). For the most recent discussion of the topic, see SINDACATIDI VOTO E SINDACATI DI BLOCCO, supra note 166. See also Didier Martin, Les conventions de vote en France, in SINDACATI DI VOTO E SINDACATIDI BLOcCO, supra, at 377 .

172. Art. 10(4), Law of Feb. 18, 1992, No. 149, recently amended by Law of July 30 , 1994 , No. 474. The publication of the content must be made in three national newspapers. Less extensive disclosure was previously mandated pursuant to CONSOB regulations.

173. "[T]here are in nature animals and plants we are able to see only in particular circumstances. This is the destiny of shareholders' agreements ....": Gaetano Castellano, Il patto parasociale di Mediobanca; sindacato di voto e sindacato di blocco, 1985 GIURISPRUDENZA COMMERCIALE I, 342. Now, at least regarding their visibility, things have changed, as their existence and content must be published (see supra note 172). One of the circumstances in the past in which it was possible to see shareholders' agreements at work was the battle for the control of Mondadori s.p.a, which was fought in the open and involved the use of every possible judicial weapon.

174. Some shareholders' agreements, however, are clearly drafted to avoid the possibility of being struck down by the courts. This is the case of the shareholders' agreement involving Fiat s.p.a., supra note 162 . 
In resolving this last issue, the judicial trend toward the invalidity of shareholders' agreements may play some role. Often such agreements provide for liquidated damages, and even more often they provide for self-enforcing techniques that effectively prevent adhering shareholders from withdrawing their shares before the expiration date. Thus, the anticipated outcome of a controversy with other shareholders may influence a shareholders' decision whether to tender in violation of a shareholders' agreement or not.

The Italian experience with hostile takeovers is still too little to advance a seriously based prediction on the behavior of shareholders' agreements in such a setting. An attack from a hostile bidder on a shareholders' agreement at the end of 1994 was unsuccessful, ${ }^{175}$ this may be a sign that, when other rules are broken or other relationships are endangered, economic rewards may not be enough, or must be higher than normal, for the kind of actors that control Italian companies. ${ }^{176}$ Such a situation may change in the near future, however, if, as is almost certain, new actors will enter the arena. We will explore this point below.

\section{H. The Nature and the Structure of the Control Group of Italian Companies.}

We now know how strong shareholders as a group are in listed and unlisted Italian companies, and how they arrange corporate governance; what we do not know is who they are and why they own shares. This is possibly the most interesting point. We have seen supra that control groups are normally very strong. In probing more deeply, let us look into the control group, searching for the dominant shareholder, if there is one.

According to the CONSOB, as of August 1992, only ten companies listed on the major stock exchange did not have a well-defined control group; apart from one exception, ${ }^{177}$ however, the largest shareholder of these companies owned between 12.99 and $40.48 \%$ of the capital. All other companies had a stable control situation: twenty-two others had a dominant shareholder, owning between 34.93 and $49.47 \%$; seven others had a shareholder that, although

175. In the fall of 1994, a hostile bid was launched by Banca Commerciale Italiana s.p.a. for Banco Ambroveneto s.p.a, at the time governed by a shareholders' agreement gathering more than 50 percent. The bid, after being rejected by the members of the agreement (although with some coordination difficulties due to a shareholder willing to sell) was withdrawn. After the buyout of the dissenting shareholder, the agreement was first extended and then redrawn with less participants (see Antonio Quaglio, Patto a tre per Bazoli, IL SOLE - 24 ORE, July 25, 1995, at 25).

176. Of course, it may also be that the bid was considered too low by each of the parts of the shareholders' agreement, in which case the agreement played no role at all.

177. Assicurazioni Generali, one of the largest insurance groups in Europe, was shown as having its largest shareholders at $5.96 \%$, but this number was later corrected to more than $12 \%$ due to a calculation which included shares temporarily issued to Mediobanca s.p.a. and not yet claimed by the holders of long-term warrants. 
syndicated with others, dominated the company with a holding ranging between 31.01 and $66.40 \%$; fifteen had a stable controlling syndicate ranging between 50.00 and $63.99 \%$. The remaining listed companies, i.e., around 150 , had a shareholder having more than the absolute majority. ${ }^{178}$ Things have changed slightly since then, in some case significantly, but the overall ownership pattern still shows a very high concentration.

More importantly, both data and day-to-day experience show that most dominant or controlling shareholders of listed companies have traditionally been directly involved in the management of the company for a long time. Families of the founders or strong individuals control each company, either by themselves or jointly with other large shareholders. This is all the more true for unlisted companies, due to the factors noted above (IV.D).

The remaining members of the controlling group, in turn, are normally large or controlling shareholders of other companies and are sometimes involved in related industries. Shared control and minority holdings, when significant and part of a broader agreement, tend to form webs of stable interfirm relationships. Such relationships, however, remain mostly one-directional: ${ }^{179}$ the law confines cross-ownership to small percentages of the capital, and circular ownership, although not expressly prohibited, faces some obstacles. ${ }^{180}$

178. Comunicazione CONSOB No. 92005380, in GaZZETTA UfFiclale, Aug. 3, 1992, No. 181. I have neglected data on the "Mercato ristretto," regarding them as without great significance. Apart from the banche popolari (supra notes 155-156), such data showed an even higher ownership concentration.

179. Also for this reason, interfirm ownership seems to have little to do with the type found in the Japanese keiretsu, as described by Ronald J. Gilson \& Mark J. Roe, Understanding the Japanese Keiretsu: Overlaps between Corporate Governance and Industrial Organization, 102 YALE L.J. 871 (1993). The effect of shareholders' associations, however, may be similar.

180. This conclusion results from a simultaneous reading of a fairly intricate set of provisions. As the general provisions, C.c. ant 2360 (Italy) prohibits cross-issuance of shares, and C.c. art. 2359-bis (Italy), as amended by Legislative Decree of May 2, 1994, No. 315, limits to 10 percent the capital of the parent company that all the subsidiaries together can own and requires that the purchases be made only with earned surplus. This provision is complemented for listed companies by art. 5(8) Law of June 7, 1974, No. 216, which limits direct or indirect cross-ownership (other than between parent and subsidiaries) to two percent of the voting capital (ten percent between a listed company and an unlisted one). Other important prohibitions are also included in art. 5, Law 216/1974 (e.g., the equivalence between ownership and discretionary power to vote in computing cross-ownership percentages: for example, a bank that has the power to vote its clients' shares cannot use such power to force another company to purchase its own shares). 
Institutional investors have so far been the great absentee in the Italian stock market. The global size of their investment is relatively small, ${ }^{181}$ and the portion of such investment represented by stock is even smaller. ${ }^{182}$ Some financial institutions (banks and insurance companies) are very large, but their ability to invest in stock issued by non-financial firms is limited, and it was even more so until two years ago. ${ }^{183}$ Other financial institutions are able to invest in

181. The percentages of financial activities committed to institutional investors by households in some industrialized countries were in recent years the following:

$\begin{array}{lrr} & 1985 & 1993 \\ \text { United States } & 44.3 & 54.7 \\ \text { Britain } & 25.7 & 36.8 \\ \text { Japan } & 25.3 & 34.5 \\ \text { France } & 12.3 & 27.0 \\ \text { Germany } & 21.6 & 26.1 \\ \text { Italy } & 4.5 & 9.6\end{array}$

Source: RAPPORTO IRS SUL MERCATO AZIONARIO, supra note 148. Almost identical percentages are shown, as for Italy, in Survey of Italian Banking and Finance, FIN. TIMES, Nov. 24,1994 , at 36 (high household savings on disposable income amount, but only $9.7 \%$ of the average household's financial assets entrusted to institutional investors).

182. As of December 31, 1993, institutional investors allowed to own stock (as for the banks, see recent developments infra note 183 and accompanying text) had stock amounting to only 33,778 billion liras, out of 387,964 billion liras of managed assets. The most important category of investor in stock was insurance companies (15,379 billion liras), followed by mutual funds ( 12,220 billion liras), account managers (4,573 billion liras), private pension funds $(1,435$ billion liras) and "societd d'intermediazione mobiliare" [supra note 12] (171 billion liras). The largest type of investment was Italian Govermental bonds $(229,126$ billion liras), followed by foreign securities in general $(68,312$ billion liras) and private Italian bonds $(44,400$ billion liras). Stock was then a relatively unimportant investment, both in total and in relative size.

In detail, as of December 31, 1993 the composition of assets under professional management (in billion liras) was the following:

\begin{tabular}{lcrrrr} 
& $\begin{array}{l}\text { Insurance } \\
\text { Companies }\end{array}$ & $\begin{array}{c}\text { Managed } \\
\text { Accounts }\end{array}$ & $\begin{array}{c}\text { Pension } \\
\text { Funds }(*)\end{array}$ & \multicolumn{1}{c}{ Mutual } & Funds \\
Italian Govt. Bonds & 61,875 & 97,173 & 11,591 & 51,298 & 7,189 \\
Bonds & 25,654 & 14,849 & 1,134 & 2,174 & 589 \\
Stock & 15,379 & 4,573 & 1,435 & 12,220 & 171 \\
Foreign Securities & 17,727 & 13,576 & 858 & 35,243 & 908 \\
Other & 413 & 4,320 & 6,434 & 1,140 & 41 \\
TOTAL (387,964) & 121,048 & 134,491 & 21,452 & 102,075 & 8,898
\end{tabular}

(*) Estimated in part.

(**) S.I.M. stands for "Società d'intermediazione mobiliare," supra note 12. (Source: Sige s.p.a., in Ronchetti, supra note 148).

183. The implementation of the Second European Directive on banking (No. 89/646/CEE) caused a revision of the previous separation between the banking and industrial systems. Art. 22(1), Legislative Decree of Dec. 14, 1992, No. 481, followed by art. 53(1), Legislative Decree of Sept. 1, 1993, No. 385, mandated the Bank of Italy to determine the criteria for stock holding by banks. Following the mandate, the Bank of Italy on June 23, 1993, issued a regulation allowing minority ownership in non-banking firms (up to $15 \%$ of the total capital of the firm, which can mean up to $30 \%$ of the voting capital: see supra note 37 ), provided that other 
stock, but their total ownership is not very significant. ${ }^{184}$ With few exceptions, in the portfolio of banks and insurance companies, then, there are only minority holdings and some controlling shares of other financial firms. ${ }^{185}$ Moreover, proxy voting rules restrict greatly the ability of financial institutions to exert influence by voting clients' shares. ${ }^{186}$

The Italian system of corporate governance does not seem to have gray tones. Very few entities exist between large shareholders directly involved in the management of the company and passive investors; only one of them is outstanding for importance and know-how, and the benefits of its actions are not generally acknowledged. ${ }^{187}$ All other institutions having a stake in listed

conditions are met (adequate monitoring structure internal to the bank, sufficient diversification, etc.).

On the opposite side-i.e., ownership of banks-the law itself limits the ownership of a bank by non-financial firms: art. 19(6), Legislative Decree of Sept. 1, 1993, No. 385 (no ownership of more than $15 \%$ of the voting capital and in no event control of the bank by an entity predominantly engaged in non-financial activity).

184. As of December 31, 1993, the total stock ownership of mutual funds was around 5\% of the total capitalization of companies listed on the Italian Stock Exchange, compared with around $10 \%$ in 1986-87. The total ownership of the first 20 mutual funds in some of the largest Italian companies ranged between as high as 7.24\% (Parmalat), 5.12\% (SAI), 4.87\% (Italcable), 4.19\% (Ras), $3.88 \%$ (Stet), to as bw as $2.53 \%$ (Benetton), $1.94 \%$ (Fiat), $0.83 \%$ (Olivetti) (source: Databank, in LA Repubblica, Apr. 1, 1994, AFFaR E Finanza, at 19). A mutual funds association (Assogestioni) recently set up a permanent commission to monitor the stock market and react to violation of formal regulations and ethical rules (see Giuliano Boggiali, Assogestioni battezza l'Authority per vigilare sulle societd̀ del listino, IL SOLE - 24 ORE, Mar. 26, 1994, at 29).

185. According to a leading expert of the field, Italian banks are not ready to accept the challenge of monitoring on non-financial firms (Mario Sarcinelli, quoted in Mario Calderoni, "Non va la banca alla tedesca," IL SOLE-24 ORE, Aug. 3, 1995, at 21). One of the few relevant cases of bank ownership in non-financial firms was the situation of the Ferruzzi group (which includes Montedison s.p.a.) in 1993-95. The group fell under the control of banks that, thanks to the above mentioned dismantling of the firewalls between banks and non-banking firms, in 1993 rescued it from a deep financial crisis through an exchange of stock for debt (see supra note 161). The controlling banks, however, far from seeing their control as a final state, are actively seeking a way to cash-out their investment, or to reduce its size in September 1995.)

186. C.c. art. 2372 (Italy) limits the number of proxies each person can be given and prohibits banks (and other people and entities, such as directors, auditors, subsidiaries, etc.) from receiving proxies. The rule was introduced in 1974 as part of a wider attempt to moralize the market and reduce separation between ownership and control, but it seems under many respects ill-conceived (see a critique by Pier Giusto Jaeger, La nuova disciplina della rappresentanza azionaria, 1974 GIURISPRUDENZA COMMERCIALE I, 554). This rule is considered burdensome and unfavorable for minority shareholders by American institutional investors (see intervicw of Howard Sherman of Institutional Investors Service, Washington D.C., in Giuliano Boggiali \& Stefania Pensabene, Italia nel mirino dei gestori Usa, IL SOLE - 24 ORE, Mar. 5, 1994, at 21).

187. This institution is Mediobanca s.p.a, which buys and holds minority stock in financial and industrial companies. The role Mediobanca has played in shaping Italian capitalism is

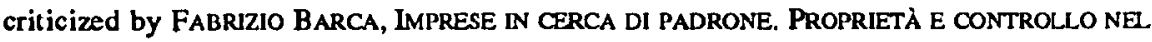
CAPITALISMO ITALIANO [FIRMS LOOKING FOR OWNERS. OWNERSHIP AND CONTROL IN ITALIAN CAPITALISM] 182, 204-06 (1994) (the institution survived the banking crisis of the early '30s as 
companies (most of them holding companies) are vehicles for outright control, whether exerted by absolute majority or by a minority but controlling block. ${ }^{188}$

The practice of hiring professional managers for the highest level posts (namely, delegated director) is widespread, ${ }^{189}$ and it seems to be entirely wise. Even so, the presence of large shareholders is strong, on the board as well as outside it, and their supervision of managers is extremely effective. We can fairly say, in sum, that large shareholders of Italian companies are nothing less than entrepreneurs with limited liability. ${ }^{190}$

virtually the sole consulting service provider, and later assumed a role of capital provider; the effects of its actions, however, have been more to reinforce group and family relationships than to ease the optimal allocation of control). A critical assessment of Mediobanca's role is found also in Mediobanca, Italy's Insider Bank, Wants To Write Guest List for Key Privatization, THE WALL ST. J., Mar. 22, 1995, at A12 (relating to the possible role of Mediobanca in the future privatization of Stet s.p.a.).

188. Ronald J. Gilson \& Reinier Kraakman, Investment Companies as Guardian Shareholders: The Place of MSIC in the Corporate Governance Debate, 45 STAN. L. REV. 985 (1993), describes the structure of institutions defined as Managerial Strategic Investment Companies (MSICs) and the legal constraint they would face in America. MSICs are institutions that make "large and active equity investments in a small portfolio of public companies" (id at 992) and create value by constantly monitoring the management of portfolio companies, participating on their boards without assuming outright control over them. The authors (id. at 992 n.29) include among examples of European MSICs the Italian Ferruzzi Finanziaria, Compagnie Italiane Riunite (CIR), and Istituto Finanziario Industriale (IFT).

This inclusion is incorrect. Ferruzzi Finanziaria, CIR, and IFI do not appear to be simple monitors; rather, they appear to fully control their portfolio companies, and particularly the most important among them (which is, respectively, Montedison s.p.a., Olivetti s.p.a., and Fiat s.p.a., controlled through a less than absolute majority stake). True, they also have minority stakes, but such stakes are more "commitments" 10 reinforce strategic alliances than financial investments. In other words, Ferruzzi Finanziaria, CIR, and IFI are not monitoring institutions, but active enterprises in every sense.

189. The delegated directors of all the largest Italian groups (Fiat, Olivetti, Fininvest, Credito Italiano, Banca Commerciale Italiana, Benetton, etc.), are professional full-time managers, some of whom have served in more than one firm during their careers. A complete study of the background of managers, their incentives, their relationship with majority shareholders, and their ability to shift from one firm to another would give powerful insights into the Italian corporate governance system. Unfortunately, such a study still has to be done.

190. This is the underlying assumption of FRANCESCO CORSI, LEZIONI DI DIRITTO DEL'IMPRESA 166-68 (1992), who proposes a "research of the lost entrepreneur" for economic policy purposes. A de facto distinction between shareholders-entrepreneurs and shareholderscapital providers, long noticed, is particularly stressed by ROBERTO WEIGMANN, CONCORRENZA E MERCATO AZIONARIO 13 (1978); Pier Giusto Jaeger, Gli azionisti: spunti per una discussione, 1993 GIURISPRUDENZA COMMERCIALE 23, 38; Disiano Preite, Investitori istituzionali e riforma del diritto delle societd per azioni, 1993 RIVISTA DELLE SOCIETA 476, 480. 


\section{Factors Determining the Concentrated Ownership Structure of Italian Companies.}

Many factors can be traced as determining the peculiar, highly concentrated ownership structure of Italian companies. A complete assessment of the factors contributing to the present shape of Italian capitalism exceeds the scope of this paper. I will list only the most relevant among them. Factors that favored the concentration can be divided into two main categories: factors that have traditionally restrained the offer of equity capital by enterprises and factors that have restrained the demand of equity capital by investors.

In Italy, many firms, even very large ones, and entire industrial sectors have developed independently of the public market. There are many reasons for this peculiar phenomenon. First, in Italy the State has traditionally offered services that in America were offered by the first giant corporations. The development of railways, cited by many as a determining factor in early American development, was carried out by large public corporations, several of which were mentioned by Berle and Means, ${ }^{191}$ whereas in Italy railway development was furthered by the State. The same can be said for public utilities. These undertakings by the State deprived the Italian public capital market of the pathbreaking examples of giant corporations, which could have been successfully imitated by other firms. And many large firms that actually were public ended under control of the State as a result of the crisis of the early ' 30 s.

Moreover, a large part of the banking sector, whose ownership amounts to a very high total value, has never gone through a public offering of equity. Most Italian banks have indeed developed as not-for-profit institutions, with their roots going back centuries, and their growth has so far been financed internally. ${ }^{192}$ (It was only in 1990 that a massive process of transformation of not-for-profit banks into società per azioni started, ${ }^{193}$ with competitive and financing goals that in large part still have to be achieved.) The public market, then, has been deprived of potential equity not only directly by the State, but also by history.

Although important, these phenomena represent only the tip of the iceberg. The reality is that the bulk of Italian private industry has grown without the

191. BERLE \& MEANS, supra note 15 , at 23. As for the case of the Pennsylvania Railroad, for example, see charts at 54-55.

192. For example, the casse di risparmio [savings banks], which together amount to a very large share of local retail banking, were foundations-public entities, as were other important banks. Most of them, pursuant to the law cited in the following note, have now undergone a process of transformation in società per azioni.

193. The process has been rendered possible by the Law of July 30, 1990, No. 218 (socalked "Amato Act," after the then Minister of the Treasury), and the following Legislative Decree of Nov. 20, 1990, No. 356. This law has allowed the unilateral incorporation of an ordinary societd per azioni by the not-for-profit entity, accompanied by the transfer of the business and of most assets to it. The not-for-profit entities have so far remained the controlling shareholders of the newly-created for-profit banks, but spin-offs are likely to occur in the coming years. 
contribution of the public stock market, and notwithstanding recent regulatory attempts to induce firms to go public, ${ }^{194}$ has very strong incentives to continue to do so.

Italians have traditionally had very high savings quotas. ${ }^{195}$ In the past, their savings were channelled into a banking system shielded from both intra-industry competition and external substitutes. Banks, then, had an abundant source of capital supply, readily available for enterprises. Banks, however, could offer only debt financing because of the restrictions laid down as a consequence of the crisis of the 30s, and most of that financing took a short-term form. ${ }^{196}$ Probably as a consequence, the tax system has always been very favorable to debt financing, allowing a complete deduction of interest expense while taxing heavily corporate income and dividends.

When substitutes for bank deposits finally appeared and European integration exposed the Italian banking system to internal and external competition ${ }^{197}$ the landscape was already shaped. Although only as lenders, banks had become the dominant form of financial intermediary in the Italian market, and enterprises continued to find it easier to resort to debt financing, which was also cheaper from a tax standpoint. The result has been that Italian

194. Among which a three-year reduction of 16 percentage points in corporate income tax for firms that are newly listed on a stock exchange, adopted in summer 1994, stands out (art. 5 , Law of Aug. 8, 1994, No. 489).

195. This is notorious: see, e.g., Survey of Italian Banking and Finance, supra note 181, at 36 (pointing out that household savings on disposable income amount to a higher proportion in Italy than in the United States, Japan, Germany, France and the United Kingdom). Having recently lost its long-standing leadership, in 1993 Italy was third among industrialized countries with $18.9 \%$ savings on disposable income, after Belgium (22.9\%) and Portugal (21.3\%), and before Greece and Denmark (15.8\%), Ireland (14.8\%), Japan (14.6\%), and France (14.1\%). Germany was tenth, with $12.1 \%$, and the United States had only $4.6 \%$. Last was Holland with $1.6 \%$ (source: data OECD, in Terza nella graduatoria Ocse. L'Italia non è più il Paese leader per il risparmio, IL SOLE - 24 ORE, July 13, 1994, at 4; see also Financial Indicators, THE ECONOMIST, Aug. 26, 1995, at 93, reporting an OECD forecast for 1995 in which Italy slides to the fourth position, after Belgium, Denmark, and Japan).

196. The banking law of 1936 , besides limiting the ability of banks to invest in equity, fragmented their activities, dividing them between short-term lenders, on the one hand, and medium-long-term lenders, on the other, the rationale being that banks receiving demand deposit could not engage in other than short-term financing. As demand deposits were the predominant form of savings, the consequence was that most of the offer of financing for enterprises came as short-term debt. Thus, the capital structure of Italian firms is unbalanced toward short-term debt, with all the problems that this causes. (See infra note 198 for further data.)

197. See ALBERTO PREDIERI, IL NUOVO ASSETTO DEI MERCATI FINANZIARI E CREDITIZI NEI QUADRO DELLA CONCORRENZA COMUNITARIA (1992), and RENZO COSTI, L'ORDINAMENTO BANCARIO (2nd ed., 1994) for ample accounts on the gradual evolution of the banking system from a virtually protected market, under the original design of the Fascist legislation of 1936-38, to a market exposed to intemal and extemal competition pursuant to the First and Second European Directives on banking. 
firms tend to have highly leveraged and bank-dependent capital structures. ${ }^{198}$ (This does not necessarily mean that Italian firms are subject to bank-monitoring: it is widely recognized that Italian banks are poor monitors, ${ }^{199}$ at least when their credit exposure is not significant.)

The consequences of the availability and of the comparative economic advantage of debt financing can be intuited. Publicly owned firms have issued less equity than they otherwise would have, thus reducing the dilution of dominant ownership stakes, and extremely large and profitable firms have remained privately owned. Significantly, Italian firms that go public often adduce reasons of corporate image rather than of corporate finance, ${ }^{200}$ and in general

198. The phenomenon is particularly marked for unlisted companies, but even listed companies tend to be quite leveraged. The result is that Italian societd per azioni, between 1988 and 1992, paid out 46 trillion liras as dividends and 450 trillion liras as interest expense on bank loans (Ronchetti, supra note 148 ). The average debtequity ratio of 152 largest private Italian groups was in 1992 close to three to one, and even higher was such ratio in small-medium firms. The overwhelming majority of the debt capital comes from banks via direct financing (source: data Centrale dei Bilanci, summarized in Supp. to Mondo EConomico, Dec. 25, 1993, at 251; Ronchetti, supra note 148; IL SOLE - 24 ORE, July 15, 1994, at 30). Moreover, such financing is generally short-term. On the heavier taxation of equity as compared to debt and the significance and scope of going public for small-medium firms see MERCATI FINANZIARI PER LE PICCOLEE MEDIE IMPRESE. ANALISI E PROGETTO PER IL CASO ITALIANO (Giancarlo Forestieri ed., 1993).

199. BARCA, supra note 187, at 207; GIANGIACOMO NARDOZZI, TRE SISTEMI CREDITIZI (1983); id., Le banche ago della transizione, IL. SolE - 24 ORE, Oct. 4, 1993, at 6; Tommaso Padoa Schioppa, quoted in La ripresa va, ma è senza credito, LA STAMPA, Nov. 15, 1994, at 27 (Mr. Padoa Schioppa is the General Manager of the Bank of Italy). The reasons for this, stressed particularly by Professor Nardozzi, are that while the banking system is strong toward enterprises, individual banks are not, having chosen the easiest, if not necessarily the most efficient, way of limiting risk: diversification. Each bank lends a relatively small amount of money to each enterprise, which in turn resorts to multiple banks for its needs. Each bank is sure of losing a given percentage of loans to bad debtors, but it is unlikely to suffer losses heavier than the class of banks of the same kind (which is satisfactory for bank managers, according to the notorious phenomenon that managers risk more when the firm underperforms the market than when all the market performs badly; therefore, having asymmetric risks and asymmetric incentives, managers may consciously pursue suboptimal strategies: MiCHAEL E. PORTER, COMPETITIVE STRATEGY (1980)).

Moreover, Italian banks perform virtually no consulting function since the banking crisis of the 30s (BARCA, supra note 187, at 204-0.5), possibly as a consequence of width of the portfolio of debtors.

Using a very effective metaphor (John C. Coffee, Jr., Liquidity Versus Control: The Institutional Investor as Copporate Monitor, 91 COLUM. L. REv. 1277 (1991)), we could then say that Italian banks have chosen "liquidity" rather than "control"; the economic system, however, is a net loser, as good entrepreneurs receive the same conditions as bad ones. We could then explore the reasons for this behavior, which in my view, not unlike the diagnosis of Professor Coffee for institutional money managers, lie in the lack of incentives for credit managers of banks to invest resources in selecting good borrowers.

200. This strange motivation is noticed by Attilio Ventura, quoted in Ronchetti, supra note 148. Mr. Ventura is a leading observer of the Italian stock market and is presently the Chairman of the Stock Exchange Council, supervisory authority on the Italian Stock Exchange set up by 
entrepreneurs are wary both of going public and of letting in new shareholders. ${ }^{201}$ Besides tax and economic factors, cultural factors also play a significant role. ${ }^{202}$

So far we have examined why firms have not resorted to the public stock market. Other elements, not less important, explain why investors have not found stock particularly attractive, or in any event why there has been relatively little demand for stock. First, up to now Italy has had, and even after the 1995 reform will continue to have, a pension system mostly based on the intervention of public or quasi-public agencies that tend to use the cash paid by present employees to pay benefits to retired workers. Nothing like American pension funds, one of the driving forces of American capital markets, ${ }^{203}$ exists in Italy; Italian pension funds are made up only of voluntary, additional and therefore necessarily limited, retirement savings.

Furthermore, a huge public deficit has forced the State to continually drain capital from the public, thus diverting a large part of household savings from private capital markets into the Government's ailing coffers. In recent years, average Government bond yields, pushed up by the State's increasing financing needs, have been higher than most stocks. ${ }^{204}$ Although this phenomenon cannot account entirely for the underdevelopment of the Italian stock market, ${ }^{205}$ it is

at. 24, Law of Jan. 2, 1991, No. 1. Many voices claim that going public would nevertheless be beneficial for many small-medium firms (see also supra note 147 for some impressive data on how many Italian firms would be eligible for listing), but many of them point at the costs of listing as a deterring obstacle (see Alberto Ronchetti, $E$ le aziende tornano a respirare, MoNDo ECONOMICO, Oct. 15, 1994, at 84).

201. MINISTERO DEL' 'NDUSTRIA \& MEDIOCREDITO CENTRALE, supra note 113, at 248-52 and tables Nos. 68 to 72 , shows a not very high $22.2 \%$ of the firms of the sample ready to accept participative financing, $21.3 \%$ ready to accept equity financing, and a mere $9.0 \%$ of firms deeming external equity financing particularly useful as a development tool. Table No. 69 shows what firms expect from equity financing: enhanced financial soundness, easier access to bank financing and consulting services by the entering shareholder. A previous unpublished draft of MINISTERO DELL'INDUSTRIA \& MEDIOCREDITO CENTRALE, supra note 113 (draft Nov. 1993), contained a Table No. 68, which does not appear in the final version, eloquently showing what firms fear from equity financing coming from new shareholders (mainly, Joss of autonomy and managing problems). For another survey on the motives that actually induced firms to ask for listing between 1985 and 1990, and motives that may deter firms from doing it, see Evelina Marchesini, Un esercito di candidati con tutte le carte in regola, in Borsa. Guida alla Quotazione, Supp. to IL SOLE - 24 ORE, July 27, 1994, at 5, and Marco Liera, Troppi controlli e soci curiosi spaventano gli imprenditori, in Borsa. Guida alla Quotazione, supra, at 7.

202. Jody Vender, quotod in Giuliano Boggiali \& Ettore Livini, La Borsa dei piccoli parla europeo, IL SOLE - 24 ORE, Nov. 15, 1994, at 28.

203. See Gilson \& Roe, supra note 179 , at 898 .

204. Emanuele Scarci, Dividendo limitato/Azionisti di minoranza. Mai più parco buoi, Mondo ECONOMICO, Aug. 6, 1994, at 68.

20.5. Giangiacomo Nardozi, Nel capitalismo made in Italy $i$ limiti del listino, IL SOLE - 24 ORE, Sept. 17, 1991, at 21 (stressing that the competition coming from public bonds is a relatively recent phenomenon, while the Italian stock market has always had a limited size). 
likely to have played some role. ${ }^{206}$

\section{J. Completing the View. Factors Determining the Ownership Structure as a Whole: Long-term Entrepreneurs and Short-term Companions.}

In the preceding paragraphs we have seen that Italian unlisted companies, apart from very few exceptions and from change in alliances, are closely held and do not have well-defined majorities and minorities. We have next seen that listed companies, although widely held, are usually controlled by a stable control group formed by interested owners, and we have examined the structure of such control groups. We have then explored the causes of the peculiar, concentrated ownership of Italian companies. It is now time to complete the picture, examining who the remaining, non-interested, owners are, and why they invest their money in the firm.

Large shareholders involved in the management of the company have an incentive to retain earnings. On the one hand, profit retention is instrumental to the long-term view controlling shareholders are naturally inclined to follow. On the other hand, controlling shareholders are less likely to be affected by a systematically low stock yield, as they are able to be compensated through salaries, strategic alliances, acquired social prestige or other means. ${ }^{207}$ Not only does the Italian legal system not discourage this practice, but it actually encourages it, at least to some extent. The exceptionally heavy taxation of corporate income constitutes a strong incentive to conceal earnings, and the financial reporting system, although less than before, renders some underestimate of income possible. ${ }^{208}$

206. The daily trading volume on the Mercato Telematico Secondario dei Titoli di Stato [Governmental Bond Automated Exchange] reached 30 trillion liras in February 1995, while at the same time the daily trading volume on the Italian Stock Exchange did not pass one trillion liras, and its all-time record is around two trillion.

207. As preemptive rights can be waived only in specific cases and following a reinforced majority vote of shareholders (See supra note 40), stock options as an incentive for directors are quite difficult to implement once the company has gone public. The closest substitutes are longterm warrants that directors receive in their quality as shareholders (i.e., in proportion to their ownership).

When the company is privately owned, shareholders are able to profit not only from salaries that zero-out reported income, but also by shifting a part of personal expenses on to the firm: see Claudio Dematte, Il Fisco spiazza l'erede in azienda, IL SOLE - 24 ORE, Feb. 9, 1995, at 13 (pointing at the perverse effects of taxation on both the capital structure and the ease of the succession process in family-owned firms).

208. The transparency of reported earnings was significantly improved by the reform carried out by Legislative Decree of Apr. 9, 1991, No. 127, which implemented the Fourth and Seventh European Directives on the subject. The reform has on the one hand solved some issues over which there has been tension among shareholders (see, e.g., Judgment of Feb. 27, 1985, No. 1699, Cass. civ., 1985 LE SOCIETA', 870: LIFO does not constitute an underestimate of income; 
Profit retention produces an immediate selection among investors. The ability of shareholders other than those interested in the management to cash in retained earnings is limited to capital gains. ${ }^{209}$ Not every investor, however, can focus its strategy on capital gains. On the one hand, the need for liquidity resulting from a capital gain strategy obviously discourages investors who follow it from buying large stakes and becoming actively involved, ${ }^{210}$ while, on the other hand, the taxation of capital gains is more favorable for investors who sell small stakes. ${ }^{211}$ The tax regime of equity investment, coupled with the presence of large shareholders, not only influences the relative proportion of debt and equity, but also influences how equity is subdivided. In other words, it shapes the total ownership structure of the firm.

Multiple factors combine to make shareholders of Italian companies cluster at two extremes: either controlling, interested entrepreneurs or small, disinterested investors. Shareholders' agreements fit the picture as compromises between the difficulty of dominant shareholders in retaining control and their reluctance to lose it. (It is my opinion, however, that shareholders' agreements

the law now expressly allows it when adopted on a consistent basis). On the other hand the reform explicitly prohibits outright underestimates of income (see for instance C.c. art. 2423(4), 2324-bis (3), (Italy)). No law, however, can completely prevent financial reporting from being an extremely powerful governance tool (Berardino Libonati, Final remarks at the Meeting of the University of Florence, School of Economics, on the new law on financial reporting (Apr. 22, 1994)).

The law of Aug. 8, 1994, No. 503, in my opinion, marked significant regress on the road of faimess in financial reporting. This law allows depreciation and other income-reducing items for tax purposes to be used for financial reporting, thus assimilating two kinds of financial statements that serve totally different purposes. The change took place without any previous discussion by experts of corporate governance, probably as the result of a lobbying effort by strong ownersmanagers to which the government was sensitive.

209. The focus on capital gains may help explain why the Italian stock market, as far as price/earnings ratio is concerned, is very expensive as compared to others, and why new, highpriced issuances of stock are usually fully subscribed (see Francesco Micheli, Questa Borsa cosi depressa e arretrata continua a essere la più cara d'Europa, IL SOLE-24 ORE, Oct. 30, 1991, at 23; Nardozzi, supra note 205; Scarci, supra note 204; a few signs of a slowdown of new issuances are observed in 1995: Fib 30 promosso nel semestre, supra note 148). Average industry yields range between a low of $1 \%$ of the price in the insurance industry and a "high" of $2.5 \%$ in the banking and trade industries. Companies' cash flow is indeed very high as compared to reported income, thanks to the reasons stated in the preceding note. This capital gainorientation is seen in the Italian stock market's Jack of sensitivity to change in dividends. (For some interesting examples, see Scarci, supra note 204).

210. A capital gain focused investor needs liquidity, which by its very nature discourages not only an involvement in control, but also the purchase of substantial stakes (Coffec, supra note 199).

211. Until a few years ago, Italy did not tax capital gains. Now, after the Government Decree-Law of Jan. 28, 1991, No. 27, converted by the law of Mar. 25, 1991 No. 102, and subsequently amended, the taxation of capital gains is waived for sale of stakes of less than two percent of listed companies. The past system strongly encouraged liquidity, and the present system still does. 
are probably also a response to industrial organization problems. ${ }^{212}$ ) Large investors buy substantial stakes only if they can participate in the control group. Where this is not possible, they abstain from buying.

The picture is now complete. Italian companies have some strong, real owners, as well as many passive beneficiaries of their achievements, or lack thereof. Italian shareholders either manage the company long term, or tend to invest in it short term.

The nature of the Italian stock market is fully consistent with this assumption. It has frequently been said that the Italian stock market privileges short-term gains, ${ }^{213}$ and it could not be otherwise. Transfers of control do not usually take place in the market, so that when the controlling stake is transferred short-hand, the law compels a sort of "shotgun wedding" between the buyer and the market: the buyer must launch a tender offer for the same quantity of shares at the same price. ${ }^{214}$ Moreover, the law, by forcing the controlling shareholder to launch a tender offer for the remaining shares when the float falls below a certain level, recognizes the fact that the Italian stock market is a market for the exchange of minority blocks. ${ }^{215}$

Paralleling further Professor Roe's definition of the American corporate landscape, ${ }^{216}$ we can say that Italian corporate governance is based on a triangle formed by strong owners, faithful managers, and short-term companions.

\section{K. Italian Corporate Governance: Some Final Remarks. The Majority Stake as the Most Important Institution of Italian Capitalism.}

As we have seen throughout the paper, the main feature of the Italian corporate governance system is the role of entrepreneurs. It is here that qualities and limits of this system reside. Scholars debate over whether it is best that powerful financial institutions monitor managers or that the market monitor them, and interest groups fight over which model to "suggest" to developing

212. See infra note 231 and related text.

213. NOMISMA, RAPPORTO 1991 SULL'INDUSTRIA TTALIANA 113-56 (1992); Preite, supra note 190 , at 477.

214. Art. 10(8), Law of Feb. 18, 1992, No. 149, on tender offers. This follow-up, mandatory tender offer increases the cost of acquisitions, thus creating an obvious obstacle to transfers of control that should be carefully weighed against the benefits of the resulting deepening of the market (see a very questionable interpretation of the law, given by CONSOB in connection with the privatization of Sme s.p.a., in In arrivo il si della Consob sull'Opa Sme, IL SOLE-24 ORE, Feb. 7, 1995, at 24, explicitly justified by the need to reduce the cost of transfer of control over the company). Any assessment of the effects of this provision is still premature, as significant changes are being observed from 1992-93 to 1994-95.

215. Art. 10(9), Law of Feb. 18, 1992, No. 149. The level of float below which the mandatory residual tender offer is triggered is generally set at 10 percent, but can be reduced by the CONSOB on a case-by-case basis.

216. RoE, supra note 16. 
economies. ${ }^{217}$ They may be missing an alternative: reducing agency costs by leaving management of firms to directly involved shareholders who are not monitored, but simply restrained in their otherwise absolute freedom by external institutions such as antitrust law, specific antifraud provisions, etc.

This possibility may be too simplistically stated, but at least it is worth considering. I do not see, for instance, an a priori advantage in fostering the creation of a public stock market in economies that lack a market culture, ${ }^{218}$ or in committing to newly born financial institutions a monitoring function that proves to be extremely difficult even for mature financial institutions in mature economies. ${ }^{219}$ As a safer alternative, I see fostering entrepreneurial culture and product market institutions at the expense of a growth in average firm size in the short run, if necessary. In other words, as entrepreneurs have a spontaneous incentive to perform well, an approach that privileges "buy" over "make" may be much more self-enforcing than one based on delicate checks and balances that require decades to be built. ${ }^{220}$

Italy is a living demonstration that such an approach can work and be extremely beneficial. Until very recently, banks have not been allowed to own stock, and even now they cannot control the voting process through proxies. ${ }^{221}$ Other institutional investors are small, or are not otherwise very influential. Therefore, the largest part of the productive system has been financed almost exclusively through debt coming from banks abundantly supplied by large household savings. The availability of alternative sources of financing, coupled with other causes previously examined, has rendered development of a large stock market less critical. This is not necessarily good, but it shows that alternatives to both stock market and financial institution monitoring exists, compelling

217. See a description of attempts to influence Eastem European countries to adopt either the German or the American model in Mark M. Nelson, Two Styles of Business Vie in East Europe, The Wall ST. J., Apr. 3, 1995, at A10.

218. Which is the underlying motive of many studies on the subject favoring the adoption of rules that encourage monitoring by outside shareholders. Experience shows that very rarely, even in mature economies, investors buy large stakes with external monitoring as the sole means of protecting their interests; it is very unlikely that this could happen in a developing economy, in which the management faces less external constraints.

219. In Germany, the case of Sctneider, supposedly monitored by powerful banks, and in France the repeated bailouts of Credit Lyonnais, crippled by an overly active investment policy, while not allowing radical conclusions to be drawn as to the alleged ineffectiveness of financial institution monitoring (which are instead drawn in After Schneider. Germany should stop pretending that its corporate govemance is working well, THE ECONOMIST, Apr. 16, 1994, at 20), at least suggest that such activity is particularly difficult and, therefore, should not be left to less than very experienced financial institutions.

220. The debate over business law in Russia and other Eastern European countries seems in certain cases to overlook the intrinsic difficulty of public market and institutional monitoring and the far from absolute reliability of financial institutions in emerging countries.

221. See supra note 186. 
scholars to consider not two (as they do now: supra note 1 and related text ), but three alternative models of corporate governance.

The Italian industrial system has developed on the basis of an almost absolute coincidence between ownership and control. Equity is typically in the hands of directly involved shareholders, and the remaining part of the capital comes, as debt, from institutional lenders. When the growth of the firm requires more equity and endangers the exercise of control, strategic alliances among large shareholders tend to emerge. Therefore, the system and its formal and informal institutions, rather than allowing management to remain in control, have allowed owners-entrepreneurs to remain managers. ${ }^{222}$

This seems to be the Italian path. The many advantages are obvious, as are the many disadvantages. Although its governance model cannot be suggested as suitable for every social and economic environment, Italy demonstrates that, absent institutional investors and/or stock market pressure, other "institutions" come into play and keep the industrial system going. What instead remains to be seen is what model prevails absent regulatory constraints. It has been well argued that the Berle-Means corporation is the product of adaptation to regulatory constraints. ${ }^{223}$ Instead, we do not know if the Italian corporation is solely the product of adaptation to other constraints, and particularly to the constraints on equity ownership by banks. In other words, we do not know if in the United States a large availability of bank capital, 224 coupled with GlassSteagall limitations ${ }^{225}$ but without any restraint on non-bank shareholders, would

222. A significant example of tilted perspective is the otherwise remarkable paper by Randall Morck et al., Management Ownership and Market Valuation, An Empirical Analysis, 20 JOURNAL OF FINANCIAL ECONOMICS 293, 297 (1988). The authors, analyzing data on most Fortune 500 firms and finding only 14 of them totally management-controlled, write: "These results also corroborate the hypothesis ... that firms in which management owns over $50 \%$ of the equity (and thus has complete control) should have a hard time surviving as organizations."

This statement seems affected by a logical flaw. The fact that few Fortune $\mathbf{5 0 0}$ firms are totally management-controlled supports only the proposition that it is problematic to reach a very large size while at the same time retaining complete control, and does not support the proposition that totally management-controlled firms do not grow or do not survive. The quoted statement could be logically translated in the following hypothetical report of an extra terrestrial for his or her home planet: "Humans can be short or tall. As few humans shorter than four feet are older than twenty, it follows that short humans usually die before reaching the age of twenty." (See infra note 239 , for an analysis of this paper.)

223. ROE, supra note 16.

224. Id. at 54-59, points out that the deliberately fragmented banking system was "incapable of easily financing the new large scale industry": "[ $t$ hose financing the new large enterprises ninety or a hundred years ago could not go to a big bank for one-stop shopping. No single bank was capable of providing the necessary financing."

225. On the prohibition against bank equity ownership, embedded in the Glass-Steagall Act and in other previously enacted sections of the National Bank Act, and in general on the deliberate regulatory efforts to weaken American banks and financial institutions, see RoE, supra note 16, at 26-49 and 94-101. The trend is now reversing, as a wave of bank mergers in 1995 testifies, and the recent case NationsBank of North Carolina N.A. v. Variable Annuity Life 
have produced an Italian-style governance model instead of creating a mass stock market. Nor do we know if in Italy, absent the Glass-Steagall-like barriers erected after the collapse of the ' 30 s, banks would have directed capital also to Germanstyle large equity stakes instead of advancing capital only as loans. ${ }^{226}$

If there is uncertainty as to what the optimal model is, there is none as to the useful role of bank credit. The availability of bank financing widens the number of available alternatives, giving mid-range firms the option whether to go public or not. Moreover, banks are in a good position to fend for themselves with the debtor and to assess the debtor's risk. Thanks to bank financing, many large, if not exceptionally large, Italian firms (as well as German) go public when they choose to do so, and are not forced to do so as soon as they grow. Despite some very well-argued differing opinions, I do not see anything intrinsically wrong in this. Going public has its costs, ${ }^{227}$ and the availability of more options normally means more efficient choices. ${ }^{228}$

Insurance Co., 115 S. Ct. 810 (1995), seems to be a signal of the political consensus for the attempt to disen franchise banks fiom regulatory constraints. (In an important footnote 2, the Court stated: "We expressly hold that the 'business of banking' is not limited to the enumerated powers in 824 Seventh [of the National Bank Act] and that the Comptroller [of Currency] therefore has discretion to authorize activities beyond those specifically enumerated.")

226. See also Ronald J. Gilson, Corporate Governance and Economic Efficiency, in ASPECTS OF CORPORATE GOVERNANCE. THE STOCKHOLM SYMPOSIUM 13.1, 137-38 \& n.17 (Mark Isaksson \& Rolf Skog eds., 1994), for possible path-dependent explanations of the present role of Japanese financial intermediaries in corporate governance.

227. "Going public is a relatively time consuming and expensive means of raising capital, although the commensurate benefits may more than outweigh these disadvantages in the appropriate situation." (Carl W. Schneider et al., Going Public: Practice, Procedure and Consequences, 27 VILL. L. REV. 1, 50 (1980), reprinted, with later revisions, in RICHARD W. JENNINGS ET AL., Securities Regulation 164, 185 (7th ed. 1991)). Costs of being publicly owned for Italian firms are variously assessed (Giancarlo Pagliarini, Federalismo, ma non in borsa, IL SOLE - 24 ORE, Apr. 9, 1994, at 25; Franco Gallo, quoted in Marco Liera, Consob e Bankitalia frenano le nozze fra banca e impresa, IL SOLE - 24 ORE, Mar. 23, 1994, at 32), ranging between 300 million and one billion liras a year.

228. Two recent Italian works stand out for their completeness and the depth of their arguments in favor of a radical transformation of the Italian economic system and corporate governance. Preite, supra note 190, proposed a governance model based on separation between ownership, more than fifty percent of which should be on the market, and control, coupled by active monitoring by institutional investors and, if necessary, hostile takeovers. (Professor Preite, who died prematurely in 1994, was a young and extremely brilliant graduate from Milan and Yale.) He strongly favored shareholders-entrepreneurs to be replaced by professional managers, constantly submitted to the scrutiny of the market. I do not fully share this idea. First, the risks of managerialism may be less important than the risks of entrenchment, but they are very serious, as very serious are the problems encountered by proposals aimed at selecting effective monitors (see, for example, the problems of outside directors monitoring in Ronald J. Gilson \& Reinier Kraakman, Reinventing the Outside Director: An Agenda for Institutional Investors, 43 STAN. L. REV. 863 (1991)). Monitoring by institutional investors, suggested as a solution (Preite, supra, at 519), is not an easy road at all. Moreover, as I noted above, the practice of selecting professional managers is widespread among Italian companies, and I think that "strong owners" 
An assessment of the efficiency of Italian corporate governance follows the

give at least some assurance that managers are effectively monitored (at most the problem being that the latter are too "faithful", i.e., they lack autonomy). Second, I have problems with any argument that starts from the risk of inefficient use of private property to mandate solutions. Therefore, I concede that a shareholder with more than the absolute majority can be an inefficient manager or monitor of managers (as Professor Preite stated, for instance, at 504-05) and cannot be replaced. However, I do not see on the basis of which theory he or she should be expropriated of the right to manage the firm (of course, once minority shareholders are given some basic protection against abuses, on which the Italian system is weak: see infra, part IV).

Similar, in many respects, is BARCA, supra note 187 , a comprehensive work on the structure of Italian capitalism. (Mr. Barca is manager of research with the Bank of Italy, and has been a visiting scholar at MIT). Mr. Barca's thesis is that the Italian system creates obstacles to the optimal allocation of control, thus preventing the natural selection of the most efficient users of the asset-firm. The diagnosis seems to be correct overall, and the thorough critique of some institutions of Italian capitalism and of the role of the State in the economy is convincing (id at 187, 204). I cannot follow the argument, however, when it blames Italian capitalism for being a "capitalism without anonymous property," i.e., where ownership and control coincide (id. at 185). Again, it is possible that non-anonymous (indeed, extremely active) owners will not be the most efficient ones, but I do not see any justification that compels the expropriation of their stability, so long as the means by which they retain control are fair. (What is fair, in turn, may be debatable.) Monoover, it is possible that shareholders' entrenchment limits growth, but this is not the end, since the market is a possible substitute, and often a very efficient one, for hierarchy. In other words, I agree that transfers of control should be eased, but I do not carry the argument to the conclusion that it should always be possible even against the will of the owner (i.e., in practice, by means of a hostile takeover).

Objections to this kind of approach can go even further. What is "efficient" depends on a variety of factors, only part of which is strictly economically driven. In the same way that firms cannot be considered simply factors of production (as Coase, The Nature of the Firm, supra note 116, taught us). Also ownership rights over firms cannot be considered simply "factors of ownership," the efficiency of whose allocation can be measured regardless of the entire context. The context determines not only which class of "patrons" will own the firm (and on this aspect see the pathbreaking work by HANSMANN, supra note 156), but also how ownership will be structured among a class of patrons. For instance, the ownership structure of a closely held firm may be "inefficient," or "suboptimal" (this statement is rather common in Italy), but, given the people that run it, or given many other factors, a widely held firm might never have been born or might not have survived. (See the consideration of intangible factors that possibly contribute to shaping industrial organization in Ronald J. Gilson \& Mark J. Roe, supra note 179, at 899. Japanese traditional reluctance to use the courts may have imposed a higher degree of vertical integration, which is a non-adversarial governance technique of long-term relationships.)

Therefore, which ownership structure is best, if there is one, is only partly assessable using solely economic tools, and it is an extremely difficult target of regulatory interventions. The preferable approach is not that of mandating solutions, but of creating alternatives (ROE, supra note 16 , at xi). Once broad economic policy goals are set and regulatory-supervisory agencies are established, the availability of alternatives would presumably yield the ownership structure. Very strong arguments seem necessary to second-guess the optimality of spontaneous arrangements (" [] $\mathrm{t}$ is a reasonable research strategy to assume that the agreements reflect the purposive behavior of the parties." (Victor P. Goldberg, Relational Exchange: Economics and Complex Contracts, 23 AMERICAN BEHAVIORAL SCIENTIST 337 (1980), reprinted in VICTOR P. GOLDBERG, READINGS IN THE ECONOMICS OF CONTRACT LAW 16,17$)$ ). 
finding that it is based on the action of strong owners. Among the advantages, reduced (or absent) agency costs 229 and convergence of interests among shareholders stand out. An active shareholder prevents managerial slack without incurring the possible conflict of interests inherent in a multi-dimensional monitoring. ${ }^{230}$ Shareholders' agreements can be viewed as an institution that performs a useful role in industrial organization by creating long-term relationships among firms. ${ }^{231}$

Among the disadvantages, one finds risk of appropriation of corporate wealth and entrenchment (not by managers, but) by controlling shareholders. ${ }^{232}$ While many institutions impose constraints on the ability of controlling shareholders to appropriate corporate resources, at least when the company is exposed to the attention of the public, the risk that controlling shareholders, fearing loss of control, may inadequately capitalize the firm is serious. ${ }^{233}$

229. The well-known, black letter proposition that agency costs are inversely correlated with the managers' share in the firm's residual earnings is stated by Michacl C. Jensen \& William H. Meckling, Theory of the Fim: Managerial Behavior, Agency Costs and Ownership Structure, 3 JOURNAL OF FINANCIAL. ECONOMICS 305 (1976).

230. Gilson \& Kraakman, supra note 188, at 1004-06 \& n.82.

231. A key to the study of shareholders' agreements could lie in their comparison with the long-term relationships that make up for the Japanese keiretsu. The agreements could be considered "credible commitments" to stabilize long-term business relationships, whose governance would be costlier otherwise (OLIVER E. WILLIAMSON, THE ECONOMIC INSTITUTIONS of CAPITALISM (1986)).

Of course, much of the debate is made of policy arguments. Mr. Barca, for instance, focuses on the fact that shareholders' agreements, by tying ownership with non-transferable relationships, reduce transferability of control, BARCA, supra note 187, at 185; Professor Preite disfavored them as obstacles to an effective institutional and market monitoring (Preite, supra note 190, at $546 \&$ n.175, $551 \mathrm{n.191}$ ). As previously discussed (supra note 228), my opinion is that clear evidence of undesirable effects, particularly on third parties, is needed to deny the efficiency of relational arrangements chosen by fully informed parties. A consideration of the alleged negative effect of shareholders' agreements on the public stock market is not sufficient if it is not supported by evidence that the costs entailed are higher than any other possible efficiency gain (i.e., particularly, transaction costs savings in the peculiar Italian setting).

232. A broad analysis of the possibilities of appropriation of corporate wealth by managers can be found in Eugene H. Fama \& Michael C. Jensen, Separation of Ownership and Control, 26 JoURNAL OF LAW AND ECO. 301 (1983).

233. Preite, supra note 190 , at 505 . See the case of a recapitalization that caused the controlling family ownership to fall below 50 percent, which clearly was forced only by a serious financial crisis (that later worsened), in Ora Fochi teme la scalata, IL SOLE - 24 ORE, Feb. 2, 1995, at 27.

The risk of inadequate capitalization is an inevitable by-product of the power of shareholders to decide on the issuance of shares. In fact, no rule can force a controlling or simply influcntial shareholder to vote a recapitalization that dilutes his or her influence. Only two alternatives are possible: (1) either managers are empowered to issue all the shares they deem necessary, as it is de iure or de facto the case in the American system (apart from some exceptions and stock exchanges rules requiring shareholder approval of certain large issuances) or (2) shareholders have tight control on the capital structure, as is the case in most European systems. Both have benefits 
Particularly worrisome, finally, is the risk that powerful and strongly interested owners may collude with regulators and public agencies to obtain unlawful advantages. ${ }^{234-235}$

and costs, and as incentives of controlling and non-controlling shareholders may differ, the choice of which of the two is better may depend on the predominant ownership structure. A system based on the influence of large shareholders may then suggest the adoption of the "European" approach, as absolute managerial discretion would change nothing in the substance, while subtracting the decision on capital structure to the disclosure, the checks and the balances imposed by the law on shareholders' voting. Therefore, the recurrent definition of the risk of insufficient capitalization of the firm as one of the possible "conflicts between the reasons of property and the reasons of business" is descriptive, but does not carry any prescriptive meaning as long as managers are not totally freed by shareholders' influence, which in turn carries other negative consequences.

234. In Italy, the issue of business ethics is very serious, as the recent wave of investigations has shown. It is a matter of notoriety that since February 1992, Italy has undergone what can be termed a "bloodless revolution." The bulk of investigations concerned illegal payments made by entrepreneurs to politicians and bureaucrats to influence public construction or supply contracts. The blame fell more on the bribed than on the bribing,

who-no matter here how justly-claimed a sort of "state of necessity."

235. It is at least debatable, however, that a concentrated ownership structure is socially more dangerous than a dispersed one. Large and stable ownership, besides increasing the incentive to corrupt by increasing the share of benefits that such action yields to the corrupter, also increases public exposure, which has powerful restraining effects. One or more visible owners face more constraints by engaging in socially questionable conduct than managers that may claim that they act in the interests of anonymous shareholders and that have the alibi of maximizing their wealth (even when such wealth comes as a transfer from someone else's). The unscrupulous and aggressive, even if largely lawful, business behavior of the tobacco companies in westem countries in the past and in developing countries today, is a clear example of lack of managerial moral constraints. (I want to stress that my point does not concern the question whether managers should enhance interests other than those of shareholders; it only concerns the extent to which managers are allowed to pursue the interests of shareholders. I am not advancing any theory about the issue of the social responsibility of the corporation.)

The position expressed in 1 American LaW InstTute, PRINCIPLes of Corporate GOVERNANCE: ANALYSIS AND RECOMMENDATIONS $\$ 2.01$ (b)(2) (1994) is interesting but somewhat affected by ambiguity: "Even if corporate profit and shareholder gain are not thereby enhanced, the corporation, in the conduct of its business: - (1) Is obliged, to the same extent as a natural person, to act within the boundaries set by law; - (2) May take into account ethical considerations that are reasonably regarded as appropriate to the responsible conduct of business ...." (emphasis added). Although the accompanying Comment (id. at $h$ ) states that making corporate decisions also on the basis of non-profit-maximizing ethical consideration is "not only appropriate, but desirable," the literal formulation of $\$ 2.01$ (b)(2) does not recommend such conduct: it only insulates managers that follow it from liablility.

By contrasting mandatory compliance with the law and voluntary observance of "ethical considerations," ALI places an enormous reliance on the promptness of the legal system in identifying and prohibiting every kind of unjustified wealth transfer, an ability which seems to me at least doubtful. (The problems encountered by even the most meritorious suits against the tobacco companies for their past conduct are evidence that complete reliance would be misplaced.) Passibly, ALI is giving up any attempt to curb the powerful force of the public stock market, pragmatically settling for objective criteria. 
What is the role of the Italian public stock market as a governance institution? Its role is limited, but not negligible. Besides being a source of equity capital for large firms, ${ }^{236}$ the public stock market is a (semi-strong) monitoring device on management. Indeed, although shareholders' concentration (and not the existing law) ${ }^{237}$ usually prevents the controlling group from being replaced through a hostile tender offer, the stock market can put an inefficient management under strong pressure. Actual cases show that managerial entrenchment does not depend only on the size of ownership as some studies seem to assume, ${ }^{238}$ and it is not complete even with the possession of the absolute majority of voting rights. Formal and informal mechanisms, other than hostile takeovers, may come into play.

It is clear that Italian corporate governance must be perfected, but its advantages and disadvantages cannot be separated. The incentive to a good performance that comes from large shareholdings may cause the entrenchment effect as a by-product. The stability that allows the managers' a long-term view may also reduce their incentive to maximize shareholders' wealth in the short as

In sum, I strongly doubt that capitalism with anonymous property is socially more responsible than a capitalism with well-identified owners. (A dissimilar view seems to emerge in Giangiacomo Nardozzi, $/$ capitalismo tutto in famiglia, IL SOLE - 24 ORE, Apr. 24, 1994, at 22. where Italian industrial families are blamed for having turned to the Government to seek protection against competition. This is certainly true, but it remains to be seen if such behavior is to be traced to family concentrated ownership.) A different issue from desirable ownership structure is that of desirable business size, which underpins large parts of the American legal system: see ROE, supra note 16, at 21-49, although with particular focus on the fragmentation of financial institutions. Antitrust law, of course, is the most powerful tool of economic policy dealing with the issue of desirable business size.

236. See supra note 209 , for the relative ease with which Italian firms can raise capital from the public.

237. The Italian law on tender offers has a double-face effect. It renders costlier the transfer of control by means of direct purchase of a controlling share, but restricts the target's management ability to implement defensive tactics once the hostile bid has been launched (respectively, art. $10(8)$ and art. 16, Law of Feb. 18, 1992, No. 149, on which see mixed thoughts supra note 214). This solution was modeled after the Thirteenth European Directive Proposal on company law (see Gilson, supra note 117).

238. The outcome of the recent crisis of the Ferruzzi group (supra note 185) is a clear example of the role played by the public stock market in such a setting. The group, due also to mismanagement by the members of the controlling group, fell in the spring of 1993 in a very serious financial crisis. The creditor banks not only managed to rescue it by giving up part of the credits and exchanging part of them for stock, but also obtained a liability suit against directors to be instituted through a shareholders' majority vote, both by the parent and by the largest subsidiary. While the first part of the agreement is a normal, value-creating step towards the solution of a financial crisis afflicting a productive business, the second is much less usual in Italy, as a suit against directors can be brought only if a majority of shareholders authorize it (C.c. art. 2393 (Italy): supra III.C.2). It is strongly arguable that, absent the pressure coming from the stock market, the deal between the majority shareholders and the banks would not have included any liability suit. 
well as in the long term. ${ }^{239}$ Therefore, an analysis of Italian corporate governance

239. Recent studies have examined particularly the effects of ownership structure and shareholders' concentration on performance. None of them yields results warranting the conclusion that one kind of ownership structure is absolutely better than others. Harold Demsetz \& Kenneth Lehn, The Structure of Corporate Ownership: Causes and Consequences, 93 JOURNAL OF POLITICAL ECONOMY 1155 (1985) find no absolute correlation between ownership concentration and performance of the company, but find some positive relationship when the firm has unstable profits, as the wealth gain a large shareholder can achieve increases when managerial performance is actively monitored.

The findings of Morck et al., supra note 222, who studied a large sample of Fortune 500 firms are very enticing. The authors verify the relative influence of the proposition by Jensen \& Meckling, supra note 229, that agency costs increase with separation between ownership and control and the various theories according to which managers' control is likely to reduce other, countervailing incentives. The authors find that Tobin's $Q$ (ratio of the firm's market value to the replacement cost of tangible assets, chosen as a proxy of the firms' performance), increases markedly between $0 \%$ and $5 \%$ of board ownership, then decreases between $5 \%$ and $25 \%$, and finally increases slightly above $25 \%$. The authors' hypothesis is that while agency costs decrease constantly as percentages of board ownership increase, managerial entrenchment increases significantly, more than offsetting the decrease in agency costs, between $5 \%$ and $25 \%$, a percentage beyond which it is extremely difficult for hostile takeovers to succeed. This data seems to warrant the conclusion that some board ownership is good, but that too much is bad.

The authors offer some alternative explanations for the results of the experiment (id. at 312, increase in managerial ownership, rather than being the cause of the increase in Tobin's $Q$ between $0 \%$ and $5 \%$, is its effect, induced by the exercise of stock options by managers of successful firms) and offer different criteria to evaluate what good performance is (id. at 312-13, non vahue-maximizing behavior can be efficient for managers who have control). Nevertheless, this study appears a sophisticated statistical application on an ill-chosen sample. It does not seem wise to choose Fortune 500 firms to study board ownership, i.e., to choose huge, manufacturing firms to assess ownership by relatively few individuals or entities: increasing the cost of control, large firm size is not a neutral factor in analyzing concentrated ownership. Therefore, giant comprations do not seem to me the right starting point to study the effect of board ownership on performance. (It is true that there are a few majority-owned firms even among Fortune 500 firms, but it is likely that they are exceptions, and it is at least arguable that their control has been retained because of some underperformance.) The problem of perspective casting doubts on the full acceptability of the study emerges from the statement quoted supra note 229.

A possible alternative explanation of the results reached in Morck et al., supra, is offered in Clifford G. Holderness \& Dennis P. Shechan, The Role of Majority Shareholders in Publicly Held Corporations. An Exploratory Analysis, 20 JoURNAL OF FINANCIAL ECONOMICs 317 (1988). This study is particularly interesting, as its sample consists of a large number of majority-owned firms, whose performance and other characteristics are measured against those of a random sample of comparable firms. The authors suggest that Tobin's $Q$ may not be the right proxy to assess the performance of majority-owned firms as it does not fully incorporate any premium associated with transfer of control, which for majority-owned firms, alchough higher than zero, tend to be bwer than for diffusely held firms (id. at 327-33,342). In other words, stock price in majority owned firms does not reflect, or reflects in a lower measure, the premium shareholders usually get when control is transferred in a friendly or hostile takeover. (This may suggest that the "shotgun wedding" forced by the Italian law on tender offers examined supra note 214 and accompanying text, and even more the British mandatory $100 \%$ tender offer in connection with transfers of control, spreading over all outstanding stock the control premium, could induce a better sample 
based only on shareholders' entrenchment and on the virtually non-existent possibility of hostile takeovers would be one-sided and a little naïve, ${ }^{240}$ as would be a mere apology for the strength of small-medium Italian firms. ${ }^{243}$

Possibilities for opportunistic behavior by the majority, however, remain. Moreover, important changes are to be expected, changes that may render the now existent legal framework dramatically inadequate. The thrust provided by the majority stake, on which Italian capitalism has relied so far, could not be sufficient anymore to fully support the further development of the economic system. Part V, by proposing the introduction of minority shareholders' suits against directors for acts in conflict of interest, will try to offer a partial solution to this problem.

\section{The Way Ahead: The Foreseeable Developments.}

The previously described image of Italian corporate governance may undergo some significant changes in the years ahead. Many factors may contribute to inducing alternative corporate governance patterns, and in particular a pattern of bank monitoring, which will flank that based on the direct involvement of large shareholders. Possible causes include:

(a) In the next few years thousands of Italian firms will experience a generational transition, determined by demography. ${ }^{242}$ Many among the most prestigious and active Italian firms were indeed founded between the '50s and the ' 60 s, and they will soon face such a problem. According to estimates of experts, the transitional process will be massive, and its outcome will be of critical importance. ${ }^{243}$ The solution of transition problems usually requires high liquidity,

to measure the performance of majority-owned firms, as it spreads the control over all the outstanding stock.) The authors conclude that there is no significant difference between the performance majority and diffusely-held firms, and there is no evidence that majority shareholders use their influence to expropriate or consume corporate resources.

240. A bit paradoxically, a takeover-related reading of corporate law comes sometimes from Italian scholars. Much of the debate about the validity and the effects of the clause requiring transfer of shares to be approved to take effect for the company ("clausola di gradimento," see supra note 136) is based on its alleged antitakeover effects (see, for instance, Floriano d'Alessandro, Le azioni, in DiRrTto commerciale 250, 278-79 (Vincenzo Allegri et al. eds., 1993)), when virtually none of the many thousands that have this clause in their charter is a possible takeover target.

241. A balanced assessment is made in Italian small business. Change in the heartland, THE ECONOMIST, Apr. 2, 1994, at 73.

242. See Mancello Zache, Dinastie industriali: generazioni al bivio, MONDO ECONOMIco, Nov. 20, 1993, at 89.

243. Paolo Jovenitti, quoted in Zacchè, supra note 242. 
and it is foreseeable that often liquidity will come from the public market or from bank equity financing. ${ }^{244}$

(b) The stock market is going to witness an extensive offer of equity that the actors now on the scene cannot satisfy. Privatizations of very large stateowned firms and massive recapitalizations by non-profit banks now turned into società per azioni ${ }^{245}$ require capital widely in excess of that available to listed firms and to their present owners. A dominant role of the largest bank groups is not only predictable, but it is already on the horizon. ${ }^{246}$ Although a change in the tendency to retain profits-with all that means for corporate governance-will probably follow by bank-owned companies, ${ }^{247}$ what the overall governance pattern of these companies will be is far from clear.

(c) New institutional investors are appearing, whose potential, depending also on important political choices to be made, can turn out to be very high. While closed-end investment funds will not dominate, they seem likely to thrive in the Italian universe of healthy medium firms, provided that they are granted a less unfavorable tax regime than they are now. ${ }^{248}$ Many medium firms could be financed and could eventually go public as an effect of closed-end fund financing. As for private pension funds, their future depends on the choices regarding the

244. It is very likely that succession problems, more than midstream, ordinary financing, will constitute one of the primary settings in which Italian banks will intervene as equity capital providers.

245. See supra note 193.

246. See I vertici Imi e Ina stringono i tempi per i nuclei stabili, IL SOLE - 24 ORE, Mar. 4, 1995, at 28 (role of Cassa di Risparmio delle Provincie Lombarde, Istituto Bancario San Paolo di Torino, Monte dei Paschi di Siena, as "stable core" of shareholders in the privatized Istituto Mobiliare Italiano); Gianni Dragoni \& Antonella Olivieri, Sale la febbre per la Stet, IL SOLE - 24 ORE, Mar. 9, 1995, at 25 (discussion of the future "stable core" in Stet) ("nucleo stabile," or "stable core," is an Italian translation of the French "noyau dur," i.e. the group of large shareholders charged with assuring stability to the management of newly privatized companies).

247. This is the (sensible) forecast of some fund managers, cited in Scarci, supra note 204. Using the analytic tools of transaction cost economics, we could say that financial institutions are more interested in immediate profits than in long-term industrial relationships, as their performance is easily comparable within the industry and their activity requires a lesser degree of integration with the activity of the firms they finance. (For a complete theory on the payoffs from vertical integration see generally WILLIAMSON, supra note 231; on transactional advantages and disadvantages as cause of the natural selection of the class of "patrons" that most efficiently can own the firm see HANSMANN, supra note 156; on firm's performance comparability as a cause of benefits from its concentrated ownership structure see Demsetz \& Lehn, supra note 239, at 1158 60 , whose suggestions on firm's performance instability as a cause of higher degree of ownership concentration can be logically extended to the payoffs from vertical integration in general.) True, the Japanese experience with bank-centered keiretsu may also suggest an interest of banks in longterm industrial relationships, but I am nevertheless convinced that bank ownership will at least reduce, even if not eliminate completely, the present very high profit-retention ratio of Italian companies.

248. They have been recently regulated by Law of Aug. 14, 1993, No. 344. Their major feature is their ability to invest in equity of unlisted companies. 
public Social Security system, but the huge current public deficit renders the development of these funds almost inevitable. ${ }^{249}$

(d) Recently enacted regulations aim at boosting the importance of the stock market by granting exceptionally favorable tax advantages to companies that choose to go public 250 and by allowing minor stock exchanges to be established. ${ }^{251}$ The effects of both of these interventions cannot presently be assessed, but they are likely to cause an increase in the resort to public capital markets by firms of medium size.

\section{The Need to Reform the System to Provide Strong Minority Monitoring.}

The expected increase in the importance of banks and of the public stock market urges us to rethink the continuing adequacy of the present legal framework of corporate governance. Bank ownership and new companies that go public mean more minority shareholders. An efficient system requires them to be protected and encouraged to invest in the firm. ${ }^{252}$ The "new" generation of minority shareholders will probably demand more than paternalistic benevolence from majority owners. Their ability to monitor and, if necessary, to intervene will be critical.

Although Italian antitrust law is very recent, ${ }^{253}$ and antitrust culture, particularly among regulators, is totally absent, the small average size and the economic environment provide the large majority of firms with sufficient incentives to perform well. ${ }^{254} 255$ Even where it is competitive and efficient,

249. Private pension funds have been regulated by the Legislative Decree of Apr. 21, 1993 , No. 124. Their importance seems to have been boasted by the general reform implemented with Law of Aug. 8, 1995, No. 335. Accurate forecasts about their future role, however, are not possible yet.

250. See supra notes 24 and 194, for tax breaks and advantages allowed by art. 4, 5, Law of Aug. 8, 1994, No. 489. For a comment about the opportunities offered by these incentives see Attilio Ventura, La Borsa si e modernizzata ma l'impresa resta lontana, in Borsa. Guida alla Quotazione, supra note 201 , at 2.

251. CONSOB Regulation adopted on Sept. 30, 1994, No. 8469 (supra note 22).

252. It is foreseeable that a higher level of investment in equity, especially by powerful business groups like banks, will create political pressure to reduce or eliminate the present tax disparity between debt and equity.

253. Law of Oct. 10,1990, No. 287, almost literally modeled after the antitrust law of the European Union (art. 85, 86 Treaty of Rome, Regulation No. 4064 of Dec. 21, 1989).

254. Due to the small average firm size, most Italian product markets are extremely fragmented. Italian firms are exposed to foreign competition, which mainly comes from the European market, and they compete abroad. In recent years - also thanks to the devaluation of its currency - Italy has been consistently running a large commercial surplus.

255. The opinion expressed in Competition in Italy. Call it authority?, THE ECONOMIST, Apr. 8, 1995, at 60, is not justified. Acknowledging the work done so far by the Autoritd Garante della concorrenza e del mercato [Italian antitrust commission], the article goes on to say: "The 
however, product market monitoring is not enough, as its mechanisms sometimes work too late and are too costly.

"Society wins if [corporate] governance works."256 In this respect, Italy stands only on one leg: the incentives and the self-discipline of large shareholders. Other forms of control over the performance of the company and its management are not completely effective ${ }^{257}$ or are totally absent. ${ }^{258}$ The restriction on shareholders' suits comes from a Civil Code that openly favored entrepreneurs, although as instruments of public policy. ${ }^{259}$ They are not anymore, and they are now completely free to make their own choices, for which they must accept full responsibility.

The rule that prohibits shareholders' suits (Civil Code art. 2393 (Italy)) has probably limited minority investments until today. Part $\mathrm{V}$ offers a valuation of the present impact of such rule on corporate governance, and the conclusion is that it effectively compresses the powers of minority shareholders. This may have been costly, but it may be much more so in the future: deterring investments by banks or by other institutional investors, and deterring minority investments

Autorita is less than four years old and operates in a country where competition is often frowned upon. More than anywhere else outside Asia, Italian business is built around dynastic alliances. Family empires, such as Fiat or Olivetti, do not necessarily share consumers' enthusiasm for letting more foreign cars or computers into Italy." Id. Here, rhetoric prevails over logic. First, there is a reasoning gap between the article's assessment of the internal governance structure of large Italian companies ("dynastic alliances") and the alleged anticompetitive effect of that structure, which manifestly would be an effect external to the firm. Second, the competitiveness of markets, fortunately, is not to be measured by the intent of those who compete, who very often would prefer to eliminate competitors, but by the concrete situation of the markets themselves, which can be very competitive despite any participants' effort to the contrary. In other words, what is relevant here is not what Fiat and Olivetti (or Wolkswagen, or Renault) would do, but what they can do, and the answer is to be looked for in the European and national antitrust laws as well as in their enforcement.

256. See ROE, supra note 16, at ix (referring to the lack of reaction to economic and technological changes by some large American firms, a lack of reaction possibly due to poor corporate govemance).

257. As is the case, for instance, of the monitoring by creditors: apart from the structural weakness of Italian banks' monitoring, alluded to supra note 199, it is a notorious fact that creditors are not necessarily value-maximizers for shareholders. Monitoring by other institutional investors is weak because they have very small equity ownership (supra note 182).

258. The Italian law prohibits proxy fights de facto (supra note 186), and the stock market, although an important source of pressure in the event of a crisis, does not assure a performance valuation on an ongoing basis (the market being rather thin and capital gain-oriented: supra note 209). Moreover, very rarely management can be replaced through a hostile takeover (supra Part IV.E).

259. See supra note 5 , for the role of managers as instruments of the superior economic interest of the enterprise and the Nation, envisioned by the Fascist legislation. 
in general, may have dramatic effects. ${ }^{260}$ A reform is necessary now, before it is too late.

\section{N. Summary of Part IV.}

The prevailing Italian corporate governance pattern and an assessment of it can be summarized as follows.

A. The Italian industrial system.

A.1. The relevance of small-medium firms in the industrial system is higher in Italy than in other industrialized countries. The overall productivity of Italian and foreign firms, however, is comparable.

A.2. A substantial part of the Italian GNP comes from the public enterprise system, whose large size has path-dependent and political causes. The trend is towards a massive privatization process, but a sure forecast on what the size of the Italian public system will be in the future is not possible.

\section{B. The ownership structure of Italian companies.}

B.1. Most Italian firms, even very large ones, are unlisted and privately held. Their ownership structure is extremely closed. Private companies do not usually have clearly defined majorities and minorities and are controlled by an individual or by a group of closely related individuals.

B.2. Consequently, the public stock market is comparatively less important in Italy than in other industrialized countries, as only few very large companies (about 240 in June 1995) are listed on a stock exchange.

B.3. The ownership structure of listed companies is based on the influence of large shareholders who often have the absolute majority of voting rights. In many Italian listed companies large shareholders set up stable associations that, due to judicial disfavor, rest more on participants' reputation and economic incentives than on their own binding force. Such associations may be playing a relevant role as industrial organization institutions that allow the governance of long-term relationships, but any assessment of them, independent of policy implications, is particularly difficult.

B.4. The remainder of the ownership structure of listed companies is made up of small capital gain-oriented shareholders, who invest short-term and have no voice in the management of the companies. Financial institutions, due to an only recently removed ban on equity holding by banks, play a limited role in the stock market.

B.5. Shareholders of Italian companies cluster at two extremes: either controlling, interested entrepreneurs or small, disinterested investors.

260. It is not by chance that very often the scholars most sensitive to economic problems have favored derivative suits: see, e.g., 2 ASCARELI, Schemi di progeti di legge sulle intese industriali e commerciali e in tema di societd, in PROBLEMI GIURIDICI, supra note 4, at 933, 941 (1959); Preite, supra note 190, at 562. 


\section{Managers and monitors in Italian copporate governance.}

C.1. Although large firms often resort to professional managers, ownership and control in Italian companies are not separated. Closely held, unlisted companies are managed by $100 \%$ owners, or under their active supervision. Widely held, listed companies are managed by majority shareholders, acting alone or in stable associations, or under their active supervision. Italian capitalism is thus based on direct control of strong owners.

C.2. External monitoring on the activity of large shareholders is weak. Financial institutions are marginally involved as equity holders. Minority shareholders have little or no voice either in management or in monitoring. The public stock market can monitor managers and can put pressure on large shareholders, but normally cannot replace them in the control of the company.

C.3. Owners-managers of Italian companies, then, have strong incentives to perform well, but lack external monitors. The problem of lack of monitoring is particularly serious for acts in conflicts of interest, to avoid which spontaneous incentives are not sufficient.

C.4. Very important changes in the now prevailing ownership structure are to be expected in the near future, and minority shareholders will play a more important role in corporate governance than they have so far. Banks have recently been allowed to own equity in non-financial firms and they are starting to become actively involved as large, minority owners. Multiple factors will give the public stock market a more central role in Italian corporate governance.

C.5. A reform that empowers minority shareholders to bring suits against directors appears necessary to encourage substantial equity investments by minority shareholders.

V. CORPORATE GOVERNANCE IN ITALY AND the SYSTEM OF DIRECTORS' LIABILITY: A PROPOSAL FOR REFORM

\section{A. Directors' Accountability: Who are the Plaintiffs in Liability Suits against Directors?}

We have seen in Part III that directors can be liable either to the company or to individual shareholders, ${ }^{261}$ but that only the company, and not individual shareholders, can sue directors for damages they caused to the firm. We have also seen that the suit brought by the company can be instituted only following authorization by a majority of the shareholders. Civil Code art. 2393 (Italy). In synthesis, then, shareholders cannot sue directors derivatively on behalf of the

261. We set aside liability to creditors and third parties (supra Parts III.A. III.B) as negligible from a corporate governance standpoint. It must be remembered that individual shareholders are entitled only to "direct" damages, i.e., to damages other than those deriving from the loss of value of their shares (supra Part III.B). 
company, and the decision to sue is taken by the company according to the majority principle.

It is now time to examine directors' liability "in action," to understand how directors' liability is actually enforced. The starting point of the analysis is to understand who plaintiffs really are, i.e., who resorts to the courts asking for directors to be held accountable. As a statistical sample, I have chosen cases in which courts were asked either by companies or by individual shareholders, on any ground, to award a monetary recovery against directors of companies as a consequence of their action. Among all cases published between 1981 and 1992, seventy-two present this characteristic. ${ }^{262}$

We first examine actions brought by the company. Actions against directors on behalf of the company may be brought (supra III.C.2): (a) by new directors or by a specially appointed agent for the company, following authorization by a majority of the shareholders (art. 2393(1) Civil Code); (b) by a bankruptcy trustee (art. 146, Royal Decree of Mar. 16, No. 267); (c) by a temporary administrator appointed by the court following an investigation (art. 2409 Civil Code).

The overwhelming majority of suits against directors for liability to the company is brought by bankruptcy trustees. A very small number of suits are brought by non-bankrupt companies following a majority vote of shareholders. Only a tiny fraction of liability suits are brought by court-appointed administrators. ${ }^{263}$ The first finding, then, is that very rarely does a majority of the shareholders decide to institute an action for liability against directors. ${ }^{264}$

262. The statistical sample consists of a selection based on cases classified under the appropriate headings in FORO TTALIANO. REPERTORIO, annual editions between 1981 and 1992 (these years included). In selecting the relevant cases, I applied the following criteria: (a) cases where the court dealt with directors' liability only in dictum have been excluded; (b) cases classified under multiple headings have been counted only once; and (c) cases concerning the same parts, but decided at different levels (e.g., Appellate Court and Court of Cassation), have been also counted only once.

The sample includes cases decided both by the Court of Cassation and by lower courts (Appellate Courts, Tribunals). While virtually all decisions issued by the Court of Cassation are published in full text or abridged, only a relatively small part of decisions issued by Appellate Courts and Tribunals are published. The selection is made on a case-by-case basis by law review editors, and, quite obviously, decisions that are selected for publication normally involve new or unsettled legal questions.

263. See infra note 278 for an explanation of why liability actions under C.c. art. 2409 (Italy) are relatively rare.

Out of a total of 56 cases dealing with directors' liability to the company, 40 were brought by bankruptcy trustees, 14 were brought by non-bankrupt companies following a shareholders' vote, and only two were brought by administrators appointed by courts under C.c. art. 2409 (Italy).

264. Published cases do not fully reflect the predominance of bankruptcy trustees among plaintiffs in actions against directors. Two factors may contribute to such under-representation: (a) most cases brought by bankruptcy trustees do not reach the Court of Cassation level and are not otherwise published, as they rarely involve uncertain questions of law, and (b) cases brought 
It is not less interesting, however, to understand the factual patterns underlying the very few cases in which shareholders authorized an action against directors. In so doing, shareholders seem to have gone after the very people they chose, and with whom, given the Italian concentrated ownership structure (Part IV), they had such a tight relationship.

The clue is that this is not nomally the case. Directors were sued following a shareholders' vote mostly: (a) when control had been transferred and the sellers could not or did not vote to relieve the directors they elected of any liability, so that the new majority, often opportunistically, sued the previous directors; ${ }^{265}$ (b) when directors had been elected by distant, but not weak shareholders who, again opportunistically, did not hesitate to sacrifice directors to protect their own

by non-bankrupt companies, discussed infra, do normally involve particular factual situations (reversals of alliances, changes in control, etc.), and, thus, are more likely to receive attention by law review editors.

Even so, however, the results are sufficiently eloquent in showing that directors, absent exceptional circumstances or bankruptcy, are rarely held accountable.

265. In the case Judgment of May 8, 1991, No. 5123, Cass. civ., 1992 Foro italiano I, 817 , for instance, the parent company went bankrupt and the trustee sold the shares. The buyers voted for a liability suit against the former directors to be instituted by the company. In Judgment of June 22, 1990, Cass. civ., 1992 Foro ITALIANO I, No. 6278, at 1892, the control was voluntarily transferred, apparently without any covenant or other contractual device restricting the buyers from causing the company to sue the former directors; the same factual pattern occurred in Judgment of May 30, 1985, Tribunal of Catonia, 1986 GIURISPRUDENZA COMMERCIALE II, 923. In all cases directors were finally held liable.

When the company sues following a transfer in its control there is a clear potential for abuse. The new controlling shareholders may have bought the shares at a discount because of directors' mismanagement or fraud, and the recovery coming from a suit against directors may therefore come to them as a windfall. Nevertheless, there is little that a court can do to prevent such abuse, as the directors, if they are liable, must compensate the injured company (which may have minority shareholders). The windfall, if any, derives from an imperfect allocation of the value of the possible recovery between sellers and buyers, sub specie of a too low price of the shares. In Judgment of May 8, 1991, No. 5123, supra, the Italian Court of Cassation liquidated this defense with a formalistic but inevitable argument, stressing that the plaintiff was the company and not a shareholder.

The issue of potential windfalls coming from liability suits instituted after the purchase of shares has been developed in depth in American Jaw, where plaintiffs are shareholders, al though acting derivatively. See a discussion and a partial critique of the judicially created "contemporaneous ownership rule" in CLARK, supra note 53, at 650-52 (contemporaneous ownership rule may bar suits by investors better situated or less risk-averse than the present shareholders, whereas such investors might otherwise be willing to buy the shares and act as prosecutors on behalf of all the sharehoiders); see also the solution, partly different from the "contemporaneous ownership rule," advocated in 2 AMERICAN LAW INSTITUTE, supra note 235, $\$ 7.02$ ("A holder of an equity security has standing to commence and maintain a derivative action if the holder: - (1) acquired the equity security either $(A)$ before the material facts relating to the alleged wrong were publicly disclosed or were known by, or specifically communicated to, the holder, or (B) by devolution of law ... from a holder [who would have had standing to sue under (A)] ..."). 
interests; ${ }^{266}$ and (c) when the company had undergone a reversal in alliances, for which directors were the first to pay the expenses. ${ }^{267.268}$ "Real" suits, brought by companies in normal settings, were extremely rare. ${ }^{269}$

\section{B. Minority Shareholders and Directors' Liability: How Many Explicit Attempts? How Many "Undercover" Liability Suits against} Directors?

So far, our findings are consistent with the findings on the predominant ownership structure of Italian companies. If there is no real separation between ownership and control, shareholders will not normally vote to institute an action against the very people they have chosen (especially when such people are the shareholders themelves).

There is nothing inherently wrong in this. If majority shareholders manage the company, they will also bear the cost of every possible mismanagement. Therefore, it is understandable that liability suits principally arise when the electing shareholders, by an act of their will or following the insolvency of the company, have transferred control or have lost it. Is this the happy end of the story? Yes, provided that there are no minority shareholders.

But quite often there are minority shareholders, and there could probably be even more if minority investments were more attractive. Therefore, the problem of the treatment of minority shareholders cannot be judged irrelevant. only because the ownership structure tends to be concentrated. We have to look

266. This is clearly the factual pattern on which Judgment of Nov. 5, 1991, Appellate Court of Milan, 1992 GIURISPRUDENZA Traliana I-2, 384, was decided. A company 100\% owned by an Anstalt from Liechtenstein was sued by a third party for collection of a debt originated by an act stipulated by a previous director; the company, now under new management (but, apparently, with the same owner), sued the former director alleging, inter alia, that the obligation derived from an act "ultra vires." The Court rejected both the defense and the liability suit. Id.

267. A reversal in alliances originated the liability suit decided in Judgment of Nov. 11 , 1987, Tribunal of Milan, 1988 GIURISPRUDENZA COMMERCIALE II, 967.

268. In other cases the accounts of the facts do not tell whether there had been a change in control or a reversal of alliances (see Judgment of Nov. 12, 1987, No. 8337. Cass. civ., 1988 FOROITALIANO I, 3378). Finally, in some cases the factual patterns, as reported in the published opinions, are completely obscure, so that none of the alternatives (change in control, reversal of alliances, "real" liability suit) can be safely excluded (Judgment of July 9, 1987, No. 5989, Cass. civ., 1989 GUURISPRUDENZA COMMERCAALE II, 208; Judgment of Jan. 28, 1982, Tribunal of Milan, 1983 GIURISPRUDENZA COMMERCIALE II, 438).

269. See Judgment of Nov. 5, 1992, Tribunal of Milan, 1992 Giurisprudenza ITALIANA I-2, 641 (company brought on the brink of insolvency suing directors and auditors); Judgment of June 26, 1989. Tribunal of Milan, 1990 GIURISPRUDENZA COMMERCIALE II, 122 (company suing directors that committed a securities fraud). In a listed company, a "real" suit was brought in 1993 for a very high amount by Ferruzzi Finanziaria. The factors that influenced the decision to sue are accounted for supra, note 238. 
also at the other side of the coin, i.e., we have to look at how many liability suits, notwithstanding the requirement of a majority vote, have been explicitly or implicitly attempted by minority shareholders.

The research is fruitful: in our sample, almost one-fourth of the cases show attempts of minority shareholders to get around the requirement of a majority approval for suits against directors, relying on very peculiar fact patterns or on general tort law principles. ${ }^{270}$ The courts, however, sensing what the real substance of the claims were, rejected most such attempts. ${ }^{271-272}$ Thus, the empirical evidence confirms our hypothesis: often minority shareholders do put pressure on directors through liability suits, but the legal requirement of a majority approval for such suits comes into play and bars those suits.

Yet, a sensible research strategy impels us not to stop here. Given the existence of an explicit prohibition against liability suits brought by individual shareholders, cases concerning directors' liability do not seem the only place to look to discover tensions between majority and minority shareholders. Given that the rejection of minority suits is entirely predictable, minority shareholders may give up any will to fight, or may well try to turn elsewhere. The statistical sample, based on explicit attempts of minority shareholders to have directors condemned, may therefore underestimate the role of art. 2393 as a powerful governance tool in the hands of the majority.

In my view, actions brought under Civil Code art. 2409 (Italy) are a reliable proxy of what the corporate law landscape would be should Civil Code art. 2393

270. In 16 cases minority shareholders asked the court to hold directors liable for their acts. In virtually all such cases directors' conflict of interest with the company was alleged.

271. The very few successful actions brought by minority shareholders were due to the peculiarity of settings or to a loophole in the otherwise tight majority principle, a loophole that takes a toll of directors only in small, unsophisticated companies. (C.c art. 2373(3) (Italy) bars shareholders who are also directors from voting on their own liability, so that minority shareholders can authorize the action.) No authentic departures from the principle that directors can be held liable only if the majority authorizes it are found.

272. In an action brought under C.c. art. 2395 (Italy) the Court of Cassation argued that individual shareholders, absent direct prejudice (supra Part III.B), do not have an enforceable right against directors, as such right belongs to the corporation (Judgment of Sept. 7, 1993, No. 9385, Cass. civ., 1994 GIURISPRUDENZA COMMERCIALE II, 365, not included in the statistical sample, as decided later).

It is my strong opinion that this position is without basis. It is arguable that, if interpreted consistently with the recent rulings by the Constitutional Court and the Court of Cassation, general tort law (C.c. art. 2043 (Italy)) would allow recovery against directors. Therefore, the role that courts carve out for C.c. arts. 2393 and 2395 (Italy) (which taken together seem to bar both derivative suits and direct suits by individual shareholders) is suspect at best. Either the interpretation courts give is wrong, or the norms themselves are contrary to art. $24(1)$ of the Constitution of Italy, which states that "[e]veryone is entitled to take action to enforce his rights or legitimate interests." In other words, only two possibilities exist: (a) C.c. arts. 2393 and 2395 (Italy) do not preclude recovery under C.c. art. 2043 (Italy) (general tort law), or (b) they do preclude such recovery, and this clashes with art. 24(1) of the Italian Constitution. The Italian Constitutional Court has not examined such a question until now. 
(Italy) be repealed. As we have mentioned before, Civila Code art. 2409 (Italy) provides minority shareholders with the possibility of obtaining a court-ordered investigation and injunctions against directors, and an administrator appointed by the court may theoretically bring a liability suit against directors and auditors. Although the last kind of outcome is extremely rare (supra, V.A), Civil Code art. 2409 (Italy) provides minority shareholders with a crucial remedy, widely used in situations of hard conflicts among shareholders. More particularly, the use of such remedy indicates tensions concerning the way the company is managed. ${ }^{273}$

Evidence shows that minority requests for inspections under Civil Code art. 2409 (Italy) are fifteen times more frequent than liability actions against directors attempted by minority shareholders. ${ }^{274}$ In all of these cases minority shareholders challenged directors' conduct on various grounds -- most frequently conflict of interest and fraud. In most cases, shareholders sought to have the court stop directors from managing the company.

Affirming that, absent the majority vote requisite, at least a substantial part of the cases arising under Civil Code art. 2409 (Italy) would have been minority liability suits against directors appears to be just common sense. We can well say, then, that a non-superficial scrutiny of Italian cases sheds light on a very important phenomenon: the existence of an enormous quantity of "undercover" liability suits against directors.

\section{Directors' Liability Legal Framework in Action: Who is Protected against Whom?}

The Official Report of the Ministry of Justice on the Civil Code, $\S 173$, stated that one of the principles inspiring the reform was that "the fear to

273. Obviously, actions under C.c. art. 2409 (Italy) do not exhaust all the remedies minority shareholders have. Actions that challenge the validity of shareholders' resolutions under C.c. arts. 2377 and 2379 (Italy), for instance, arise from the attempt of absent or dissenting shareholders to have the court avoid a resolution approved by a majority of shareholders. Therefore, such actions also reveal the existence of tension between shareholders.

Nevertheless, legal grounds for such a course of action may vary, and a link between challenges of shareholders' resolutions and challenges to directors cannot be strictly established. Aiming at a favorable cash-out by the majority, for example, unsatisfied minority shareholders may well challenge the election of directors, alleging the illegality of the voting procedure that was followed, even though they are not able to allege any kind of mismanagement. Cases under C.c. art. 2409 (Italy) alone, therefore, are a more limited, but much more significant proxy for potential liability suits against directors.

274. The research is again based on a selection of the cases classified under the appropriate headings in FORO ITALIANO. REPERTORIO, annual editions between 1988 and 1992 (these years included). In selecting the relevant cases, I have applied the same criteria explained supra note 262. Published cases arising from a tension between majority and majority amounted to 156 , while in the same period published decisions on liability actions instituted by minority shareholders numbered only ten. 
shoulder overwhelming responsibilities must not deter the best and most conscious people from assuming an office for which their skill and rectitude are exceptionally valuable." If this was the goal, achievements fell well short of it. Besides, what has been achieved could have been achieved through less restrictive alternatives.

Actual cases concerning directors' liability show that even very dishonest people may escape from being held accountable, and very conscientious people may fall prey to authentic ambushes. In fact, the majority vote requirement protects directors regardless of what they have done (managerial errors, conflict of interest, fraud), and it leaves them without any protection as soon as the majority changes its mind, alliances reverse, control is transferred, or the company goes bankrupt. Art. 2393 Civil Code does not protect directors against meritless actions, but against minority actions. In other words, it filters plaintiffs, not actions.

If we desire that directors take even risky business decisions and manage the company effectively, actions against them must be screened. The problem is that the Italian system screens actions along the wrong line. On the one hand, a mistake, or an act in conflict of interest, is such regardless of who alleges it, and whether it has actually been committed or not, it is for the courts and not for the majority to ascertain. On the other hand, if directors must be protected against frivolous suits, they must be protected objectively and consistently, against minority shareholders as well as against majority shareholders and bankruptcy trustees.

Our empirical examination yields both meritless suits by the majority ${ }^{275}$ and intense pressure coming from the minority, which hardly can be presumed to be always meritless. The majority requirement for suits against directors, set forth by art. 2393 Civil Code, does not safeguard directors, who are at the majority's mercy, but increases the weight of the majority, which is empowered with an unquestionable right over directors' liability.

\section{Concentrated Ownership Structure and Majority Vote: Spontaneous Incentives versus Optimal Deterrence. The Different Situations of the Duty of Care and of the Duty of Loyalty.}

What are the combined effects of the majority vote requirement for liability suits against directors and the concentrated ownership structure of Italian companies?

If the costs of making collective decisions were zero and perfect information were available, shareholders would be the ideal constituency to decide whether or not the company should sue its own directors. After all, 
directors are supposed to pursue the interests of shareholders, and the latter seem well entitled to evaluate how the former discharge their duty. Neither of the preceding assumptions, however, is true: collective decision processes can be very costly, and perfect information is not cheaply available to shareholders. ${ }^{276}$ Moreover, in a concentrated ownership structure like the Italian one, we have no assurance at all that the shareholders' vote on directors' liability is objectively motivated. If the shareholders' meeting is increasingly considered an inadequate forum to decide on directors' liability in American corporate governance, it is even less adequate in the Italian case. ${ }^{277}$ Dominant shareholders, actively involved in the management of the company, are not exactly independent when the moment comes to assess the conduct of directors.

Minority shareholders, as we have seen, have a reduced ability to monitor directors effectively. They have the right to challenge certain corporate decisions and to ask a court investigation under Civil Code art. 2409 (Italy), but they do not have the right to hold directors accountable for their actions. ${ }^{278}$ Given the de

276. To the contrary, directors have typically more information than shareholders, or at least more information than a part of them.

277. See generally CLARK, supra note 53, at $649-50$ (stressing the costs of a demand on shareholders requirement, the lack of information among shareholders in public companies, and the possibility that wrongdoers influence the shareholder vote). The position of 2 AMERICAN LAW INSTITUTE, supra note 235, is less draconian: on the one hand, \&7.03 sets forth that demand on shareholders to commence a derivative action should not be required, since, as the accompanying Comment points out (id. at $h$ ), "informed collective shareholder consideration of proposed litigation is not feasible [because, as a body] the shareholders cannot realistically discuss and evaluate the often complex factual and legal issues raised by derivative actions." On the other hand, under $\$ 7.11$ "[t]he court should dismiss a derivative action ... upon approval by the shareholders of a resolution requesting dismissal of the action as in the best interests of the corporation," provided that certain conditions are met (full disclosure, approval by disinterested shareholders, and dismissal not a waste of corporate assets). Dismissal upon request of a majority of shareholders is considered a bad solution by CLARK, supra, at 650 , which stresses that "this majority vote would always be solicited by the alleged wrongdoers, who would do so at corporate expense, using their control of the proxy machinery."

Under both standards, concentrated ownership structure and strong ties between directors and majority shareholders, two features that are typical of Italian companies, are considered factors that reduce or nullify the meaning of a shareholder vote.

278. C.c. art. 2409 (Italy) provides minority shareholders with a powerful remedy, but not with a perfect substitute for derivative suits. This provision, as we have seen supra Parts III.C.2(b) and V.A, bestows upon the temporary administrator appointed by the court the power to bring a liability action against directors. While requests for inspections under C.c. art. 2409 (Italy) are extremely frequent, liability actions brought by temporary administrators are not (supra note 263). Several explanations for this phenomenon are possible: (a) C.c. art. 2409 (Italy) provides for a summary evidentiary procedure and not for a full-scale one, and therefore is more suitable for use in cases of multiple violations by directors and systematic oppression of the minority, which are only a part of the possible violations of their duties by the directors; (b) C.c. art. 2409 (Italy) provides for powerful injunctive intervention, but it.is ill-suited to grant relief against isolated acts by directors, acts whose effects have already been consummated. (See, e.g., Decree of Oct. 10, 1985, Tribunal of Milan, 1986 GIURISPRUDENZA COMMERCIALE II, 459: 
facto "emasculation" of minority shareholders as corporate monitors, we must inquire if the incentives for directors of Italian companies to perform well are adequate. The answer is: their incentives are strong, yet not sufficiently balanced.

Let us subdivide the directors' duties in the two classical categories of duty of care and duty of loyalty. In a concentrated ownership setting we are likely to observe strong spontaneous observance of the duty of care by directors, the costs of whose mistakes are borne by shareholders in proportion to their holdings. In such a setting, however, we are not necessarily likely to observe spontaneous compliance with the duty of loyalty, as, while the costs of its violation are borne by all shareholders, the resulting benefits are entirely appropriated by the violators. ${ }^{279}$

minority shareholders claimed the existerice of a typical squeeze-out pattern by the parent company and of various formal irregularities. The parent company allegedly overcharged the subsidiary's products it sold on foreign markets, pocketing the spread. The court rejected the request for inspection, inser alia, because: (a) there was no evidence of the denounced facts, and (b) the formal irregularities had been later rectified. A full-scale evidentiary proceeding probably would have shown whether the alleged squeeze-out was actually going on or not).

279. In many respects this is the analytical framework developed in the seminal paper by Jensen \& Meckling, supra note 229. However, Professors Jensen and Meckling do not sufficiently stress the basic difference existing between violations of duty of care and violations of duty of loyalty. Their paper focuses on agency costs "as deriving from the manager's tendency to appropriate perquisites out of the firm's resources for his own consumption," which are clearly conceptually similar to violations of duty of loyalty; it construes what resemble violations of duty of care as the product of conscious or semi-conscious manager's decisions to avoid "too much trouble or effort on his part to manage or to learn about new technologies. Avoidance of these personal costs and the anxieties that go with them also represent a source of on the job utility to him ...." (Id at 313).

This definition seems absolutely correct, but it risks blurring the fundamental difference between the effect of managerial ownership on the incentive to perform well and its effect on the incentive not to cheat. (By "managerial ownership" I mean every kind of direct link between equity holders and managers, i.e., something that goes beyond the usual understanding of the term, which in my opinion is unable to embrace fully the role of large shareholders involved, although indirectly, in the management of the company.) While incentives to perform well (duty of care), all other factors equal, are a linear function of managerial ownership, the incentives not to cheat (duty of loyalty) are more skewed. Again all other factors equal, incentives to behave in compliance with the duty of byalty depend not only on the managerial ownership in the firm, but also on the value of what the managers subtract from the firm (time, information, opportunities, physical assets, etc.) when employed elsewhere. Assuming a firm where (a) the manager is bound by a normal managerial contract, (b) he is the sole residual claimant, and (c) there are no creditors (i.e., a firm where agency costs for shareholders are zero by definition, and transfers of wealth from creditors to shareholders are not possible), the manager has an incentive to perform with absolute care, but he may be perfectly rational in deciding to violate his contractual "duty of loyalty" towards his own firm, provided that what he takes from it will be more valuable somewhere else.

In other words, as a distinction between "loss" and "transfer" of the firm's wealth makes sense, and as the size of managerial equity (as defined above) affects incentives to avoid losses and transfers differently, it follows that it is reasonable to treat them differently while examining a corporate governance system like the Italian, which is characterized by a strongly concentrated 
As for directors' incentives to act with due care, the absence of derivative actions does not seem to cause serious negative consequences. Not only do directors of Italian companies, as large equity holders or representatives of large equity holders, have strong incentives to perform well, but also shareholders' suits themselves are generally considered not to be a good remedy for enforcing directors' duty of care. American law has gradually created a complex system of protection for directors and managers and courts are wary about intervening in the merit of business decisions. Therefore, American courts rarely interfere with business judgments, although ex post ill-advised, and they have created a series of procedural hurdles that make it extremely difficult for a derivative suit based on alleged violations of the duty of care to reach the stage of the final decision. ${ }^{280}$ In conclusion, since spontaneous incentives are strong, judicial review of business decisions is inherently difficult and the cost of letting the courts intervene in business decisions may easily exceed the benefits, the prohibition against derivative actions does not seem to considerably affect the incentives of directors of Italian companies to act with due care. Perhaps the majority rule on directors' liability for violations of duty of care is not the best alternative, but at least, as the costs of such violations are spread evenly among all shareholders, it has some systematic justification.

This is not the case for directors' incentives to act loyally toward all shareholders. Here, the possession of large blocks alone is not sufficient to eliminate gains from transfers of wealth from all the shareholders to a part of them - typically, to the part of the shareholders who elect the directors. ${ }^{281}$ Directors' incentives and deterrents come from other sources, such as their need to preserve reputation, ${ }^{282}$ the fear of criminal sanctions for acts in conflict of

ownership structure. Evidence that inside ownership serves as a successful monitoring institution for negligence, but not for conflicts of interests is in fact found by Roberta Romano, The Shareholder Suit: Litigation Without Foundation?, 7 JOURNAL OF LAW, ECON. \& ORG. 55 (1991).

280. Moreover, many jurisdictions, such as Delaware, recognize the validity of charter provisions that limit liability for duty of care violations. As an example of the disfavor of American scholars towards derivative actions alleging only due care violations see 2 AMERICAN LAW INSTITUTE, supra note $235, \& 7.10$. The Introductory Note [to the chapter on derivative actions], states explicitly that "a basic distinction is drawn between the duty of care and the duty of fair dealing. Given both the evidence that due care cases rarely yield more than modest financial recoveries to the corporation ... a and the availability of other mechanisms of accountability, $\$ 7.10(a)(1)$ provides that a derivative action alleging only due care violations ... can be terminated by the board or committee subject only to judicial review for compliance with certain minimal procedures and the business judgment rule." (Id. at 6-7).

281. For an example of wealth transfer allegedly resulting from a merger between parent and subsidiary with an unfair stock-for-stock ratio, see Judgment of Apr. 26, 1993, Tribunal of Perugia, 1994 Foro ITALIANO I, 261 (upholding the chosen stock-for-stock ratio as fair).

282. Reputation as a constraint against opportunistic behavior is stressed, for instance, by Benjamin Klein, Transaction Costs Determinants of "Unfair" Contractual Arrangements, 70 AMERICAN ECONOMIC REVIEW: PAPERS AND PROCFEDINGS 356 (1980), reprinted in GoldBERG, supra note 228 , at $139,145-46$ (1989). 
interest, and the prospect of bankruptcy if the transfer of wealth threatens the solvency of the company. ${ }^{283}$ None of these incentives or deterrents, however, completely protects minority shareholders from being expropriated.

First, reputation may not work effectively in a bilateral monopoly relationship, as the relationship often is between owners-managers and minority shareholders. Moreover, criminal sanctions imposed for acts in conflict of interest do not cover all possible situations of conflict, ${ }^{284}$ and criminal courts are simply not an adequate forum to solve the largest part of the disputes among shareholders. Finally, the prospect of insolvency, by definition, does not discourage wealth transfers rationally calculated as non-solvency threatening. ${ }^{285}$

It is clear that derivative suits for violations of loyalty duties could effectively integrate the set of incentives and deterrents that directors of Italian companies presently have. ${ }^{286}$

\section{E. The Consequences of the Problematic Enforcement of the Duty of Loyalty.}

We have to keep in mind that in talking about rights of minority shareholders, we are nonetheless dealing with purely economic matters. Having found that enforcing the directors' duty of loyalty is problematic for minority shareholders, a judgment of inefficiency does not follow per se. It may well be that allowing majority shareholders a certain degree of freedom to expropriate corporate wealth is efficient, or that minority shareholders are able to discount fully the loss in value of the shares they buy that results from such freedom,

283. Not only is bankruptcy an event that directors and managers are normally likely to try to avoid as it imperils their posts, but also Italian bankruptcy law, although scarcely efficient, is particularly severe with entrepreneurs and with directors of bankrupt companies. As we have seen, directors may quite easily face liability suits brought by trustees, against which they have no more procedural protection.

284. C.c. art. 2631 (Italy) does impose sanctions on directors acting in conflict of interest, but its reach - for a series of reasons not discussed here - is not complete.

28.5. See 2 AMERICAN LAW INSTITUTE, supra note 235, \& 7.10. After describing the relative disfavor against derivative action alleging only due care violations, the Introductory Note goes on to say: "Conversely, in the case of an action alleging a breach of the duty of fair dealing, the court is permitted to review the reasonableness of the board's determinations, as well as the procedures followed and the objectivity of the decisionmaker. While limited, the authorization of substantive review reflects the greater need for judicial oversight in an area in which other mechanisms of accountability may be less able to prevent unfair self-dealing and other potential fiduciary abuse." (Id. at 7).

286. "[T]he derivative action may offer the only effective remedy in those circumstances in which a control group has the ability to engage in self-dealing transactions with the corporation." 2 AMERICAN LAW INSTITUTE, supra note 235, 7.10 Introductory Note at 5. 
thereby avoiding personal losses. ${ }^{27}$

In my view, this is not the case. First, capital markets are not perfectly efficient in anticipating every possible loss resulting from opportunistic behavior and markets for equity ownership of closely held companies, so important in the Italian industrial landscape, are not efficient at all. Moreover, high transaction costs prevent shareholders from specifying every possible contingency and effectively coping with it. Therefore, a shareholder may be effectively expropriated by acts in conflict of interest he did not anticipate or he anticipated in a lower measure. The resulting "unpleasant" surprise may well warrant the case for ex ante intervention by the law.

Second, even if shareholders were able to anticipate losses from possible appropriations by owner-managers, a "market for lemons" would follow. ${ }^{288}$ In a market dominated by uncertainty on the possible extent of future expropriations by the majority all outside, minority equity would be traded at a value that discounts future losses, even when imposing such losses, in fact, was not the intention of the owner-managers. An inefficient allocation of capital would result.

Third, the most likely consequence of the scarcity of effective monitoring powers of the minority is not only the discount of minority shares, but also the dead loss of synergies between entrepreneurs, or between entrepreneurs and capital providers. In my view, this is the worst, and probably the most realistic, scenario. Facing the difficulty of governing future conflicts among them and of solving such conflicts "fairly," different providers of factors of production may well give up on the possibility of cooperating. Thus, entrepreneurs may resort to setting up smaller, wholly owned firms, and capital providers may resort to advancing capital as loans or as equity fragmented across a highly diversified portfolio of firms. The difficulty in governance of future relationships based on equity, therefore, may yield an explanation for some of the features of the Italian industrial system.

The size of equity investments adapts to the quantity of governance power investors are granted. In a system that gives little or no power to the shareholders, like the American system, ${ }^{289}$ we are likely to observe a fragmented ownership structure. In a system that gives strong powers to majority shareholders and little or no power to minority shareholders, like the Italian system, we are likely to observe a very unbalanced ownership structure, with a

287. This is one of the most important points of Jensen \& Meckling, supra note 229, at 345 , who stated that "as long as capital markets are efficient ... the prices of assets such as debt and outside equity will reflect unbiased estimates of the [agency costs]," and therefore "the selling owner-manager will bear those agency costs."

288. This is the well-known thesis of the paper by George A. Akerlof, The Market for "Lemons": Quality Uncertainty and the Market Mechanism, 84 QUARTERLY JOURNAL OF ECONOMICs 488 (1970), reprinted in GOLDBERG, supra note 228, at 24.

289. ROE, supra note 16. 
strong control group, possibly composed of several large shareholders acting together, and small, uninfluential minority shareholders, if any minority shareholders at all. ${ }^{290}$ In different ways, both systems introduce rigidity in the organizational structure of the corporation, which may put their ability to adapt, and therefore their success, at risk. ${ }^{291}$ More particularly, the Italian legal framework discourages investors unable to enter in the control group from entering the company at all.

\section{F. What Role for Derivative Actions based on Violations of the Duty of Loyalty in Italian Corporate Governance? A Possible Contribution to the Implementation of the "Mutability Principle?"}

Derivative actions against directors for acts in conflict of interests would integrate the Italian system of corporate governance. They would fill a clearly visible gap left by a legal system biased in favor of owner-managers and, coupled with other remedies, would create an "overlapping system of protections," which best serves the interests of shareholders. ${ }^{292}$ The deterrent effect of a possible derivative action for directors facing situations of potential conflict of interest could be substantial.

It would certainly be naive to think that derivative actions could act like a magic wand, instantly able to solve all the problems and contradictions of the Italian capitalism. Shareholders that bring suit would encounter problems of information vis-à-vis directors and they would have to advance the costs of litigation. Moreover, courts would probably be burdened with actions requiring a screening and an evaluation of the faimess of transfer prices, a task which they are not necessarily well equipped to perform. Finally, some leeway for strike suits certainly would exist. ${ }^{293}$ Therefore, the small, capital gain-oriented investor

290. Constraints on the exercise of power by residual claimants require some justification. The majority principle is such a justification, but only to the extent of what has previously been agreed upon. Leaving directors the ability to act in conflict of interest, however, is something that we cannot lightheartedly presume shareholders have agreed upon.

291. The thesis that the success of organizational structures lies (also) in their ability to adapt to a continually changing environment is advanced by Gilson, supra note 117 (discussing the harmonization of European Union members' laws on takeover bids).

292. 2 AMERICAN LAW INSTITUTE, supra note 235, Introductory Note at 5.

293. The criticism that surrounds the abuses of shareholder suits in the United States, however, is strictly tied to the unique system of attomeys' compensation, and cannot be considered universally applicable to shareholder suits in general. Such compensation system introduces a personal interest of the attorney to bring the suit and later to settle it. (This phenomenon is described in John C. Coffee, Jr., The Unfaithful Champion: The Plaintiff as Monitor in Shareholder Litigation, 48 LAW \& CONTEMP. PROBS 5 Summer (1985); CLARK, supra note 53, at 657-59; KLEIN \& COFFE, supra note 53, at 196; 2 AMERICAN LAW INSTITUTE, supra note 235, Reporter's Note, at 9-12; an extremely accurate study of actual litigation involving large corporations, which aims at casting serious doubts on the overall utility of shareholders' suits as 
would probably continue to follow the "Wall Street Rule" even when there is a suspicion of conflict of interest. Informed minorities however, would have one more arrow in their bows. But, are there informed minorities in Italy? Although there are only in particular situations now, there could be many more in the future. ${ }^{294}$

As we have seen in IV.L-IV.M, important changes are taking place in the Italian industrial system. A new, dramatically important role for banks as equity holders is emerging, and a host of new types of institutional investors is going to create demand for large equity investments. It is self-evident that this kind of equity investors can possibly act as a bridge towards later initial public offerings, and, in any event, can bring valuable expertise and qualified financial support. By providing relief against potential oppression by controlling groups, derivative actions would probably improve the now rather bleak set of incentives to invest capital in a minority equity position.

These "new species" of minority shareholders will ask for a voice in the management of the company and for remedies against possible opportunism by majority shareholders. Given the doctrine embraced by Italian courts, that the corporation is a separate legal person and that shareholders cannot contractually influence its organs, ${ }^{295}$ both voice and remedies cannot be fully obtained simply by means of detailed contracts and shareholders' agreements. It is the Italian system of corporate governance in its entirety, therefore, that must prove adequate to this new challenge. ${ }^{296}$

Although a large part of the thrust of the Italian capitalism presently comes from firms owned by a handful of investors, its continuing success depends on its ability to provide new viable organizational forms and efficiently accommodate new demands. The present success of one institutional structure of production

an instrument of corporate governance, is that by Romano, supra note 279.)

The Italian system of lawyer compensation, like the systems of other European nations (e.g., Germany), differs in at least three fundamental ways from the American system, namely: (1) contingency fees are prohibited (C.c. art. 2233(Italy)a), or are anyway considered illegal by the courts (under C.c. Sec. 138(1) (Germany)); (2) "loser pays," except when the litigation was objectively uncertain or there are other special reasons; (3) average lawyers' fees are significantly lower than in the United States. Although abuses of shareholder litigation are certainly possible with this system also, the probability of their occurrence is substantially smaller than in the United States. (Of course, the drawback is that, together with the possible abuses, the benefits from the monitoring activity of interested lawyers are lost.)

294. As noted before, in closely held companies minorities are frequently the product of changes of alliances, and in publicly held companies minorities are usually uninfluential and uninformed (supra, IV.D and note 142, IV.J).

295. See supra note 167 , and accompanying text.

296. BARCA, supra note 187 , at 200-01, argues that interventions of financial institutions may be more likely if protection of minority shareholders is effective. The same point underlies the excellent paper by Preite, supra note 190. 
is no excuse for refusing to pave the way for alternatives to it. ${ }^{297}$ "In an environment characterized by constant and unpredictable change, the quality necessary for evolutionary success is mutability - an organism's ability to alter its structure to adapt to new conditions." 298 Derivative actions, by serving the needs of a new category of owners in Italian companies, could give some contribution to adaptation.

\section{G. Summary of Part V.}

The following conclusions can be drawn from the examination of actual cases concerning directors' liability and the prognosis about the probable evolution of Italian capitalism.

A. The empirical evidence.

A.1. An overwhelming number of liability actions against directors is brought by bankruptcy trustees. Suits against directors brought by non-bankrupt companies are exceptional, and are normally the consequence of a reversal in alliances or of a change in control.

A.2. Published cases, however, show a number of actions brought by minority shareholders aiming at challenging directors' business policy or acts in conflict of interest. Very rarely such actions take the form of liability suits, and when they do, courts generally reject them on the basis of Civil Code art. 2393 (Italy), which requires a majority vote to institute liability actions against directors.

B. Policy considerations.

B.1. A system of corporate governance largely built on strong spontaneous incentives for the majority, like the Italian system, can remove from the courts the enforcement of the duty of care, but cannot abstain from the close enforcement, with all possible means, of the duty of loyalty. As the shareholders' vote requirement for suits against directors lends itself to abuses and may prevent relief against violations of the duty of loyalty, the Italian legal framework proves to be dangerously weak on this particular point.

B.2. The concentrated ownership structure of Italian companies may be the product of the governance problems of long-term relationships based in equity. The lack of sufficient remedies against opportunistic behavior by majority shareholders may discourage potential suppliers of factors of production from realizing synergies by means of common ventures.

B.3. It is a fair assumption that the difficulty of challenging the majority shareholders' policy discourages investors from buying minority stakes. The costs of such discouragement are not easily quantifiable.

297. ROE, supra note 16 , at 14 (stressing that productivity successes or failures alone do not tell whether corporate governance systems in which they take place are optimal or not).

298. Gilson, supra note 117 , at 175 . 
B.4. Derivative suits against directors for conflict of interest seem to be the appropriate balance.

\section{CONCLUSION: WHAT PART FOR THE OWNERS OF THE FIRM IN A MATURE ECONOMY?}

Comparative corporate governance is, in many respects, the study of how different systems react to the same problem of separation between ownership and control. The causes of the separation of ownership and control and the different responses of various economic systems to the problem of agency cost it poses have been explained in historical perspective. ${ }^{299}$ The phenomenon of separation between ownership and control itself, however, has not.

With an industrial system characterized by reduced or absent separation between ownership and control, Italy could easily be classified as a "laggard" from a corporate governance standpoint, a remnant of a slower or of an interrupted evolutionary path. ${ }^{300}$ As some of the features of the Italian system are shared by the French system, Italy and France introduce a number of unusual questions in the corporate governance debate. It is not by chance that studies of corporate governance rarely deal with France in depth, and largely ignore Italy, ${ }^{301}$ notwithstanding that both countries rank very high among industrialized countries as to total and per capita GNP..$^{302}$

The corporate governance debate has become a debate over monitors. Professors Roe and Coffee, taking different sides, have given an answer to the question why American institutional investors have so diversified portfolios, and therefore are such poor monitors. ${ }^{303}$ This emphasis on monitoring has caused a strange phenomenon: as the owners' inability to fend for themselves has been taken for granted, in proposals for improving they have been skipped and forgotten.

Corporate governance literature should not only closely examine which institutions are better situated to monitor managers when ownership and control become separated, but also understand precisely at which point separation

299. The most complete attempt to provide a historical explanation for the emergence of different corporate govemance pattems is that by ROE, supra note 16 , who demonstrated the pathdependent, non a priori inevitable origin of the Berle-Means corporation in America.

300. The risk of considering laggards system different from those we are familiar with is stressed by Gilson \& Roe, supra note 179, at 873.

301. A clear example of the difficulties encountered by the traditional corporate governance studies in dealing with the Italian system is offered by the (otherwise remarkable) paper by Eddy Wymeersch, Elements of Corporate Governance in Western Europe, in AsPECTS OF CORPORATE GOVERNANCE. THE STOCKHOLM SYMPOSIUM, supra note 226, at 83 . The Italian system, after little data, gradually disappears from the horizon.

302. Supra note 17.

303. RoE, supra note 16; Coffee, supra note 199. 
between ownership and control is inevitable to occur. In other words, besides studying the response by different environments, or lack thereof, to the demand for monitoring, corporate governance literature should present a historic background of the demand for monitoring itself, explaining why such demand arises at so disparate levels in different environments.

A crucial question remains largely unanswered: why have owners started diversifying, instead of finding solutions for coping with the evolution of the firm? Risk-aversion, in my view, is not the whole story, ${ }^{304}$ and I suspect that intuition has tended to play a nontrivial part in previous discussions. ${ }^{305} \mathrm{~A}$ threedimensional research would follow, a research that could give interesting contributions to the debate.

In the traditional view, control by founders, or by stable, "entrenched" owners is considered a synonym of inefficiency. The lesson coming from Italian capitalism is that this is not necessarily true. ${ }^{306}$ Stable owners may create institutions that allow an efficient, or at any rate not necessarily inefficient,

304. For a sharp critique of the ability of the risk-aversion notion to explain real life phenomena see Victor P. Goldberg, Aversion to Risk Aversion in the New Institutional Economics, 146 JoURNAL OF INSTITUTIONAL AND THEORETICAL ECONOMICS 216 (1990): "the assumption regarding risk preferences should . . . be judged for [its] usefulness, not for [its] realism." Id at 217.

305. ROE, supra note 16 , at 4 , describing how America's large enterprises typically were created in the twentieth century, states: "Entrepreneurs would found a business, succeed, and make the business grow. ... Eventually the successful firm would go public, issuing new stock (or selling the founders' stock) to the public. For some firms, the stock market's role was to raise new capital; for many others its role was to provide the founders and their heirs an exit when they wanted to diversify and cash out.... Although descendants sometimes took over running the firm from the founders, more frequently hired managers did, and stock dissipated into fragmented holdings as the heirs sold off the inheritance...." Id.

This description would not be accurate if it were extended to France or to Italy. A theory of the separation of ownership and control should give us the answer to the question of why it would not be accurate. It is not a sufficient explanation to say that "[a]lthough the defects of separation are today in the spotlight ... separation of ownership and control was historically often functional (and still is), because it allows skilled managers without capital to run the firm and separates unskilled descendants from control of a firm they could not run well. Sometimes successful founders became poor managers, because their accumulated wealth allowed them to slack off but still live well, as historically was a problem in Britain." RoE, supra note 16, at 4 . Why did this phenomenon happen in a much lower measure in continental Europe than in Britain? Which social and economic "institutions" reduced the risk of successful founders becoming poor managers? Why have not American owners developed a system of professional managers and direct monitoring, which has developed in Italy? Why in the United States could not skilled managers be hired by owners, and why did the advent of professional managers mark the disappearance of owners? Why does separation of ownership and control occur at a certain level in one economic environment and at a much higher level in another?

306. See, for instance, Che non ci sera. Chrysler and Fiat, THE ECONOMIST, Apr. 29, 1995, at 75 (discussing the different role of the largest shareholders in Chrysler and Fiat, respectively Mr. Kerkorian and Mr. Agnelli, and praising the successful action of the second in overcoming a crisis in 1993). 
exercise of control. Among such institutions, the widespread resort to closely monitored, professional managers ${ }^{307}$ and the emergence of stable associations among large shareholders stand out. ${ }^{308}$

Italian corporate governance exceeds on the opposite. The historical favor for owner-managers has produced a legal framework that protects the directors they elect not only against interference in the management, but also against legitimate claims of conflict of interest. In Part V, therefore, I have proposed a legislative reform, aiming at introducing derivative actions against directors based on the violation of the duty of loyalty.

Many different models of corporate governance may exist at the same time and, possibly, in the same place. Corporate governance should try to understand them all, and suggest an array of different alternatives, each with the best possible mix of factors and each of them suitable for different settings. Reaching a standard, balanced model that includes owners, managers and monitors, however, is not easy at all. Italy is a living demonstration of how difficult such a task is.

307. See supra note 189 , for the widespread practice of hiring professional managers by Italian large firms. After all, large owners seem well-suited to monitor them effectively.

308. On agreements among large shareholders see supra, Part IV.G. 
